\title{
Magmatism in the North Atlantic Igneous Province; mantle temperatures, rifting and geodynamics.
}

\section{Malcolm J. Hole ${ }^{1}$ and James H. Natland ${ }^{2}$.}

${ }^{1}$ Department of Geology \& Petroleum Geology, University of Aberdeen, Aberdeen AB243UE, UK.

2. RSMAS/MGS University of Miami, Miami FL 33149 USA

\section{Abstract}

We have re-evaluated mantle potential temperature estimates for the North Atlantic Igneous Province (NAIP). Temperature estimates involving olivine addition to pillow-lava glasses are unreliable because host glasses formed along the liquid+olivine+plagioclase cotectic and not just the olivine liquidus. Additionally, magma chamber processes can generate picritic lavas containing only magnesian olivine, but picrites alone do not require high mantle temperatures. Furthermore, petrological models tend to over-estimate $T_{P}$ in picrites containing appreciable accumulative olivine further confusing the issue. Selected aphyric lavas from West Greenland, which cannot have accumulated olivine, suggest maximum $\mathrm{T}_{\mathrm{P}} \sim 1500^{\circ} \mathrm{C}$. Petrological models for Icelandic glasses suggest a maximum $\mathrm{T}_{\mathrm{P}} \sim 1450^{\circ} \mathrm{C}$ which is consistent with olivine-melt and olivine-spinel equilibration temperatures. However, melting of 'damp' peridotite beneath Iceland would reduce this estimate perhaps by $50^{\circ} \mathrm{C}$.

The NAIP mantle was lithologically and chemically heterogeneous and was made of a hybrid pyroxenite-peridotite lithology, the pyroxenite component being derived from recycling of subducted slabs. However, there is no necessity for the subducted slabs to have been recycled to the core-mantle boundary. Pyroxenite could have been derived from Caledonian-aged slabs that also hosted helium with high ${ }^{3} \mathrm{He} /{ }^{4} \mathrm{He}$ within the shallow mantle, which was inherited by Palaeocene or young melts. The pyroxenite component was more readily fusible than the peridotite component under the same P-T conditions, allowing variations in melt production rate throughout the province. Melting of lithologically variable mantle is consistent with observed radiogenic isotope variability in Icelandic basalts and related trace-element variations in throughout the NAIP.

We propose that magmatism in the NAIP resulted from extensional tectonics above 'warm' mantle that had been internally heated beneath thick continental lithosphere prior to continental break up. Only in areas of extension did magmatism occur, thus explaining the apparently widespread initial phase of magmatic activity. 
1. Introduction

1.1 Stratigraphy and age of NAIP magmatism

1.2 Mantle temperatures

1.3 Peridotite solidii and volatile-bearing mantle

1.4 Source lithology and its identification

2. Decompression melting of mantle peridotite, crystallization of primary magma and the origin of picrites.

2.1 Decompression melting of mantle peridotite

2.2 Crystallization of primary magma

2.3 The origin of picrite

3. The olivine-melt and olivine-spinel equilibrium thermometers for volcanic systems.

3.1 Olivine-melt equilibrium temperature estimates.

3.2 Olivine-spinel-melt equilibration temperatures - TOl-Sp (aka aluminiumin-olivine)

4. Petrological methods of estimating mantle potential temperature

4.1 Olivine addition and subtraction and estimates of primary magma compositions

4.2 PRIMELT3 temperature estimates

4.2.1 West Greenland

4.2.2 Iceland

4.2.3 East Greenland, BPIP and FIBG

5. The role of volatile-bearing peridotite in the genesis of NAIP magmas

6. Melting lithologically variable mantle

6.1 Generation of pyroxenite from recycled ocean crust.

6.2 Melting mixed peridotite-pyroxenite lithologies

6.3 Source of NAIP pyroxenite.

7. Isotopic considerations and $\Delta \mathrm{Nb}$

7.1 Crustal contamination

7.2 Isotopic arrays - Iceland

7.3 Helium Isotopes

$7.4 \quad$ Delta niobium $(\Delta \mathrm{Nb})$

8. Crustal thickness considerations

9. Towards a new magmatic paradigm for the NAIP

10. Conclusions 


\section{Introduction}

If the simple view is taken that hotspots are, by definition, hot (Courtillot et al., 2003 but see discussion in Foulger, 2012) then the information that the magmas and their component minerals can give us about magmatic temperatures, and by inference the temperature structure of the mantle, must be a key consideration when discussing the origin of apparently hotspotrelated magmatism at Large Igneous Provinces.

In this article we do not seek to provide a comprehensive account of the origins of magmatism in the North Atlantic Igneous Province (NAIP) but aim to critically examine the methods, results and conclusions relating to petrological and mineralogical temperature estimates. Like geochronological data, mantle temperature estimates tend to be treated as fixed numerical values on which to build geodynamic hypotheses. However, petrologically and mineralogically complex procedures are needed to create temperature estimates and if the methods applied are less than rigorous, misleading data can easily find its way into the literature. Before embarking on a critique of temperature estimates we will make some general observations about NAIP magmatism, and provide some background comments relating to mantle temperature, generation of melt from 'dry' and volatile-bearing mantle peridotite and generation of melt from mixed mantle lithologies.

\subsection{Stratigraphy and age of NAIP magmatism}

Volcanism in the North Atlantic Igneous Province (NAIP) has been widespread both in time and space (Fig, 1). Wilkinson et al. (2016) provide a detailed summary of all absolute ages for NAIP volcanic rocks and Horni et al. (2016) provide a regional overview of the distribution of volcanic rocks in the NAIP, which will be used throughout this article as sources for geochronological and geographical information on the volcanic rocks. Magmatism began at 61.5-62.0 Ma (end Danian - earliest Selandian) in the west of the NAIP at Disko and Baffin islands (Fig. 1), and this was broadly contemporaneous with eruption of the first lavas of the British Palaeocene Igneous Province (BPIP) on the islands of Eigg and Muck (61.9 - 62.6 Ma) and in Northern Ireland (Tardee rhyolite; 60.9 Ma). Between 60 and $56 \mathrm{Ma}$, magmatism was widespread across the entire NAIP whereas most post-55 Ma lavas are restricted to East Greenland and the Faroe Islands Basalts Group (FIBG), although localized, low-volume occurrences of early Eocene volcanic rocks are widespread (e.g. Faithful et al., 2012; Larsen et al., 2014; 2016). The FIBG spans the Palaeocene-Eocene thermal maximum (PETM; 55.8 Ma), with the stratigraphically oldest Lopra and Beinisvørð formations being pre-break-up and the 
stratigraphically younger Malinstindur and Enni formations being syn-break-up, which are comparable with the ages determined for Geike plateau and Milne Land formations of East Greenland (Larsen et al., 1999; 2009; Peat et al., 2003). In Greenland the magmatic record is nearly continuous from 62-38 Ma, except for a gap at 58-56 Ma, with 38-29-Ma lavas of the Hareøen Formation being the latest magmatic event (Larsen et al., 2016). The earliest magmatism on Iceland was at $15 \mathrm{Ma}$ (Hardarson et al., 1997) in the extreme NW of the island. Although seafloor spreading was continuous throughout the North Atlantic, a magmatic hiatus of at least $15 \mathrm{Ma}$ from $\sim 29-\sim 15 \mathrm{Ma}$ exists in the on-land volcanic rock record of the NAIP.

\subsection{Mantle Temperatures}

In common with most other Phanerozoic Large Igneous Provinces (LIPs), conventional models for magmatism in the North Atlantic Igneous Province (NAIP) require a sustained source of heat, possibly originating at the core-mantle boundary (CMB), which drives melting and ultimately continental break-up. The potential temperature $\left(\mathrm{T}_{\mathrm{P}}\right)$ of mantle peridotite is the temperature that a parcel of upper mantle would acquire if adiabatically brought to surface pressure. The mantle adiabat for convecting upper-mantle has a slope of $\sim 0.5^{\circ} \mathrm{C} \mathrm{km}^{-1}$ (Fig. 2). Ambient mantle potential temperature is best defined as the $T_{P}$ which is required to produce mid-ocean-ridge basalts (MORB) at spreading ridges and a widely accepted value is $\mathrm{T}_{\mathrm{P}} \sim 1350^{\circ} \mathrm{C}$. However, other estimates of ambient $\mathrm{T}_{\mathrm{P}}$ are $1280^{\circ} \mathrm{C}$ (McKenzie and Bickle, 1988), $1315^{\circ} \mathrm{C}$ (Green et al., 2001), $1440^{\circ} \mathrm{C}$ (Putirka et al., 2007) and $1500^{\circ} \mathrm{C}$ (Presnall and Gudfinnsson, 2011). The variability is these estimates reflects the underlying difficulties in assessing $\mathrm{T}_{\mathrm{P}}$. For clarity in the current study we use an estimate of ambient $\mathrm{T}_{\mathrm{P}}=1350^{\circ} \mathrm{C}$ which is the value most recently given by Herzberg and Asimow (2015).

The highest estimated mantle temperature for Phanerozoic LIP is $\mathrm{T}_{\mathrm{P}} \sim 1700-1800^{\circ} \mathrm{C}$ for 85 Ma picrites from the Caribbean-Columbian LIP (Trela et al., 2017). Such values are close to those for $3.5 \mathrm{Ga}$ Archean komatiites that presumably were generated when the entire mantle was hotter than present-day (Herzberg and O'Hara 2002). This led Trela et al. (2017) to suggest that a mantle reservoir as hot as that responsible for some Archaean lavas has survived eons of convection in the deep Earth and is still being tapped and is seen in the Caribbean-Colombian LIP. Current $\mathrm{T}_{\mathrm{P}}$ estimates for Palaeocene lavas of the NAIP are up to $1550^{\circ} \mathrm{C}$ (e.g. Larsen and Pedersen, 2000; 2009a; Spice et al., 2016; Hole and Millett, 2016) whereas estimates for Iceland rift zone lavas are $1583^{\circ} \mathrm{C}$ (Putirka et al., 2007), $1500^{\circ} \mathrm{C}$ (Hole and Millett, 2016) and $1480^{\circ} \mathrm{C}$ (Parnell-Turner et al., 2013; 2014; Shorttle et al., 2013; 2014; Matthews et al., 2016) and 1450 C for rift flank lavas (Hole and Millett, 2016). 
Depending on the LIP in question, it has been suggested that the mantle cools through time (Herzberg and Gazel, 2009; Trela et al., 2017) gets hotter through time (e.g. Hardarson et al.,1997; Spice et al., 2016) or fluctuates in temperature which may be a secondary signature overprinted on longer-term secular cooling or heating (e.g. Parnell-Turner et al 2013; 2014). Herzberg and Gazel (2009) and Hole (2015) noted that lavas from the Central Atlantic Magmatic Province (CAMP) and the Ferrar LIP of Antarctica (Hole, 2015), required $\mathrm{T}_{\mathrm{P}} \leq 1450^{\circ}$ $\mathrm{C}$ and that magmatism, rather than being the expression of deep mantle upwelling, was better explained by internal heating during long-term continental insulation of the upper-mantle beneath thick lithosphere (Coltice et al., 2007; 2008; Anderson, 2013). In these cases, rifting above the 'warm' mantle was driven by plate boundary forces and decompression melting of mantle peridotite at $\mathrm{T}_{\mathrm{P}}$ not substantially $>1450^{\circ} \mathrm{C}$.

There is therefore a dichotomy of views on the origin of LIPs supporting either plate tectonic (top-down) or mantle plume (bottom up) hypotheses, which in terms of the origin excess mantle temperatures equate to internal and external heating respectively. The geodynamic expressions of the two different origins for LIPs are also likely to be different. This led Courtillot et al., (2003) to propose five geodynamic signatures which may be characteristic of hotspot volcanism produced by a plume originating from deep in the mantle and concluded that Iceland matched the criteria well. However, Anderson $(2005 ; 2007)$ provided an updated hotspot list and tested this against criteria relevant to both the deep thermal plume and the shallow (plate and asthenosphere) hypotheses. He concluded that for Iceland, and therefore the NAIP, a platetectonic explanation for magmatism was the most reasonable.

\subsection{Volatile-bearing mantle}

Published data for nominally anhydrous peridotite solidi (Fig. 3) exhibit a variability of $\sim 80^{\circ}$ $\mathrm{C}$ at $3.0 \mathrm{GPa}$, the approximate depth for the initiation of melting envisaged for many NAIP magmas (e.g. Herzberg and Gazel, 2009; Hole and Millett, 2016). For example, for the solidus of Katz et al. (2003) is around $80^{\circ} \mathrm{C}$ lower at 3.0 GPa (Figure 3) than that of Herzberg and Asimow (2015). For TP estimates for Iceland, Shorttle et al. (2014) and Lambart (2017) used the Katz et al. (2003) solidus whereas Hole and Millett (2016) used that of Herzberg and Asimow (2015), the latter being the solidus on which PRIMELT3 $\mathrm{T}_{\mathrm{P}}$ estimates are based (Section 3.2). Different solidi therefore result in different $\mathrm{T}_{\mathrm{P}}$ estimates, different pressures of intersection of the adiabat and the dry solidus which in turn effects estimates of extent of melting.

The addition of water and/or $\mathrm{CO}_{2}$ dissolved in peridotite supresses the solidus to lower temperatures at a given pressure compared to anhydrous, $\mathrm{CO}_{2}$-free mantle. The oceanic upper 
mantle contains $\sim 50$ to 200 parts per million (ppm) of $\mathrm{H}_{2} \mathrm{O}$ dissolved in nominally anhydrous minerals, which relative to its low concentration has a disproportionate effect on the solidus (e.g. Sarafian et al., 2016; Michael, 1988; Saal et al., 2002; Hirschmann et al., 2009). Sarafian et al. (2016) showed that at $2.5 \mathrm{GPa}$, addition of $\sim 200 \mathrm{ppm} \mathrm{H}_{2} \mathrm{O}$ to dry nominally peridotite decreases the solidus temperature $\sim 60^{\circ} \mathrm{C}$, and for $450 \mathrm{ppm} \mathrm{H}_{2} \mathrm{O}>100^{\circ} \mathrm{C}$ (Fig. 3). The dry peridotite solidus of Sarafian et al. (2016) is close to that of Herzberg and Asimow (2015) over the pressure range of interest for initial melting beneath the NAIP and therefore provides a useful point of comparison. (Fig. 3). Importantly, the composition of melt produced from 'damp' mantle will not be significantly different from that produced from anhydrous mantle (Sarafian et al., 2016).

In experiments at $>2 \mathrm{GPa}, \mathrm{CO}_{2}$ also supresses the peridotite solidus but the effect is large even at very low concentrations of $\mathrm{CO}_{2}$ whereas by comparison the effect of $\mathrm{H}_{2} \mathrm{O}$ is mainly observable in watersaturated conditions. (e.g. Dasgupta and Hirschmann, 2006; Foley et al., 2009; Dasgupta et al., 2007; 2013; Mallik and Dasgupta, 2014; Hammouda and Keshav, 2015). Additionally, the composition of the first-formed melt becomes more silica understaurated with increasing $\mathrm{CO}_{2}$ content moving away from tholeiitic compositions such as those seen at most LIPs (e.g. Herzberg and Asimow, 2008). For simplicity, in the discussions in sections 2 to 4 below we assume that peridotite is volatile-free and we will return to the issue of volatile-bearing mantle in section 5

\section{4 source lithology \& its identification.}

Most existing models for magmatism at oceanic and continental LIP involve the melting of a mantle source of mixed lithology which includes peridotite and olivine-poor pyroxenite (e.g. Sobolev et al., 2007; 2009; Herzberg, 2011; Shorttle et al., 2013; Lambart et al., 2016; Lambart, 2017). We emphasize that estimates of olivine crystallization temperatures and $T_{P}$ estimates derived from them, are not dependent on the lithology of the source that is melting but rely on the temperature-dependent equilibrium between olivine and melt (section 3.1) or between olivine and spinel (section 3.2). However, some petrological methods of estimating $T_{P}$ (e.g. PRIMELT3 Herzberg and Asimow, 2008; 2015) are only appropriate for lavas generated by melting of anhydrous $\mathrm{CO}_{2}$-free peridotite.

Melting of mixed mantle lithologies (lherzolite, harzburgite and pyroxenite) is integral to published models for magmatism on Iceland (Shorttle et al., 2013; Lambart, 2017). The term pyroxenite is used to refer to mafic and ultramafic pyroxene-rich plutonic rocks that lack sufficient olivine ( $<40 \%)$ to be considered peridotites (Le Maitre et al., 2002). However, in terms of mantle pyroxenites, these are likely to contain only small amounts of olivine or even be olivine-free (e.g. Sobolev et al., 2005; Herzberg, 2006). When referring to pyroxenite 
derived from recycled oceanic crust, we assume $<10 \%$ olivine, the main mineralogy being pyroxenes and garnet It is generally accepted that mantle pyroxenite is derived from recycled subducted oceanic crust with recycling periods being in the range of gigayears (e.g. Hofmann and White, 1982). Alternatively or in addition, metasomatism of small-degree partiall melts at or near the low-velocity zone produces the enrichment (Niu and O'Hara, 2003). Some pyroxenite lithologies melt at a similar temperature and pressure to peridotite, may have similar melt productivity rates to peridotite and produce basaltic melt compositions (Keshav et al., 2004; Lambart et al., 2016). However other pyroxenite compositions have lower solidus temperatures at a givenpressure than peridotite and produce broadly dacitic melt (e.g., Kornprobst, 1970; Yasuda et al., 1994; Yaxley and Green, 1998; Lambart et al., 2009; Pertermann and Hirschmann, 2003). Different pyroxenites can also produce alkalic melts. Because of this diverse melting behaviour some knowledge of mantle source lithologies undergoing melting consequently is required when applying petrological models to derive estimates of $\mathrm{T}_{\mathrm{P}}$.

The $\mathrm{Ca}, \mathrm{Ni}, \mathrm{Fe}$ and $\mathrm{Mn}$ contents of olivine phenocrysts in lavas has been extensively used as an indicator of significant pyroxenite involvement in magmatism (Sobolev et al., 2007; Herzberg, 2011; Herzberg et al., 2016) and there are data of this type for NAIP lavas from Iceland, West of Greenland and the BPIP (see summary in Hole, 2018). In addition, melting of some types of pyroxenite tends to generate magmas that are deficient in $\mathrm{CaO}$ at a given $\mathrm{MgO}$ compared to peridotite-derived melt (Herzberg and Asimow, 2008). The shield-forming lavas of Mauna Loa and Koolau (Hawaii) fall into this category (e.g. Sobolev et al., 2005; Herzberg, 2006). However, fractionation of $\mathrm{CaO}$ relative to $\mathrm{MgO}$ is sensitive to the bulk mineral/melt distribution coefficient for $\mathrm{CaO}\left(\mathrm{K}_{\mathrm{D}} \mathrm{CaO}\right)$ in a magma, and some pyroxenites appear to have $\mathrm{K}_{\mathrm{DCaO}}>1$ and others $<1$ regardless of the initial concentration of $\mathrm{CaO}$ in the solid pyroxenite (e.g. Herzberg, 2011; Jennings and Holland, 2015; Jennings et al., 2016). Additionally, the same apparent deficiency in $\mathrm{CaO}$ at a given $\mathrm{MgO}$ can also be produced by fractional crystallization of augite from peridotite-derived magma at elevated pressures (>0.6 GPa) in the crust (Hole, 2018). The bulk composition of mantle rocks is also important and melting of harzburgite may also produce $\mathrm{CaO}$ difficient melts because of the lack of clinopyroxene in the source. In addition, when pyroxenite-derived $\mathrm{SiO}_{2}$-rich melts percolate into the peridotitic matrix, orthopyroxene metasomes may be formed at the expense of olivine producing a Ca-poor source for magmas. Overall, there is no single, simple method that can be applied to the major or trace element characteristics of lavas that can satisfactorily and reliably discriminate between magmas derived from these two mantle lithologies (Herzberg, 2011; Hole, 2018). 
However, an important feature of the NAIP which sets it apart from many other LIP (e.g. Siberia, Karoo, Hawaii) is that the trace element geochemistry of olivine phenocrysts in lavas does not indicate a significant role for pyroxenite in petrogenesis, but does not preclude it (Herzberg et al., 2016; Hole, 2018). The vast majority of olivine phenocrysts in lavas of the NAIP, regardless of their age or geographical distribution, have trace element compositions that are consistent with derivation from mantle peridotite.

\section{Decompression melting of mantle peridotite, crystallization of primary magma and the origin of picrite.}

The composition of melt formed from volatile-free mantle peridotite at a given $\mathrm{T}_{\mathrm{P}}$ is dominantly controlled by;

i) The temperature of the upper-mantle at the site of melting

ii) The initial pressure of melting, which is directly related to melting temperature

iii) The extent of melting

iv) The final pressure of melting which is related to the extent of melting and the age and thickness of the overlying lithosphere

v) The compositions of the rocks being melted.

Melt formed at any location and at a given $\mathrm{T}_{\mathrm{P}}$ may therefore have different compositions depending on factors iii) and iv) above. The first mineral to crystallize from most basaltic melt is olivine and the composition (forsterite content; molecular $\mathrm{MgO} / \mathrm{MgO}+\mathrm{FeO}$ ) of the olivine that crystallizes is dependent on the $\mathrm{MgO} / \mathrm{FeO}$ of the melt (e.g. Roeder and Emslie 1970; Beattie et al., 1991; Putirka et al 2007; Kelding et al, 2011). Fo (forsterite) content of olivine increases with increasing temperature of crystallization and similarly the $\mathrm{MgO}$ content of a primary magma increases with increasing $T_{P}$ (e.g. Hirose and Kushiro, 1993). The existence of Fo-rich olivine in $\mathrm{MgO}$-rich picritic lavas has therefore been used as an indicator of high mantle temperatures (e.g. Elliott et al., 1991; Thompson and Gibson, 2000; Larsen and Pedersen, 2000). Here we show that this is not necessarily the case and that picrite containing ultramagnesian olivine is an expected consequence of the plumbing of magmatic systems at a variety of mantle temperatures. Additionally, we show that picritic lavas may contain olivines with a range of compositions that were all derived from the same magmatic system at the same $T_{P}$.

\subsection{Decompression melting of mantle peridotite}

Mantle peridotite melts by decompression, and for melting to commence the upper-mantle temperature must exceed that of the peridotite solidus at any given pressure. For example, for the solidus of Herzberg and Asimow (2008) and $\mathrm{T}_{\mathrm{P}} \sim 1350^{\circ} \mathrm{C}$ melting will commence at $\sim 1.8$ 
$\mathrm{GPa}$ and, for $\mathrm{T}_{\mathrm{P}} \sim 1500^{\circ} \mathrm{C}$, at $\sim 3.4 \mathrm{GPa}$ (Fig. 2) which are the intersections of the relevant mantle adiabat with the dry peridotite solidus. This is also known as the initial pressure of melting $(\mathrm{P} i)$. Once melting begins, the upwelling melt rapidly become saturated with olivine and the melt will follow a P-T path that is nearly coincident with the olivine liquidus (Herzberg and O'Hara, 2002), the slope of which is shallower than that of the adiabat (Fig. 2). Decompression melting results in the generation of small droplets of melt which aggregate throughout the melting domain to produce accumulated fractional melts (AFM). These represent the integration of all the incrementally-produced small melt fractions over the pressure range of interest (Klein and Langmuir, 1987; Herzberg et al., 2007; Herzberg and Asimow, 2008; 2015). Lambart et al. (2016) showed that for mantle lherzolite at $\mathrm{T}_{\mathrm{P}}=1500^{\circ} \mathrm{C}$ and with melting commencing at 4.2 $\mathrm{GPa}$, melt productivity, that is the total mass of melt produced per GPa of decompression, increases exponentially to $\sim 9 \% \mathrm{GPa}^{-1}$ by $2.0 \mathrm{GPa}$ and up to a maximum of $9.5 \% \mathrm{GPa}^{-1}$ at 0.5 GPa. Such estimates are consistent with the value of of $\sim 10 \% \mathrm{GPa}^{-1}$ as derived by Herzberg and Asimow (2015) and Hole and Millett (2016).. Melting ceases when the ambient temperature becomes too cold, i.e. in the thermal boundary layer, and this is the final pressure of melting $(\mathrm{P} f) . \mathrm{P} f$ is likely to approximate to a pressure which is equivalent to the depth at the base of the coherently moving plate (the lithosphere-asthenosphere boundary) (Hole and Millett, 2016; Matzen et al., 2013; 2017; Hole, 2018). For regions of volcanism above thick continental or oceanic lithosphere, such as West Greenland or Hawaii, melting may cease at pressures of up to $3 \mathrm{GPa}$ whereas for MORB, Pf may be as little as 0.6 GPa (Herzberg and Asimow, 2015; Hole and Millett, 2016). Critically, for a given $\mathrm{T}_{\mathrm{P}}$ if the depth to the asthenosphere-lithosphere boundary is greater than the depth of the intersection of the adiabat and the dry solidus, melting cannot take place and the lithosphere is an effective lid on the melting column. The total amount of melt that can be produced is proportional to the difference between $\mathrm{P} i$ and $\mathrm{P} f$. Therefore, for the same final pressure of melting, the extent of melting increases with increasing $\mathrm{T}_{\mathrm{P}}$. However, high $\mathrm{T}_{\mathrm{P}}$ and thus high $\mathrm{P} i$ do not necessarily equate to voluminous eruption of lavas at the surface because the thickness of the lithosphere is the major influence on the amount of melt production that can take place.

Figure 4 is a schematic illustration of two different melting scenarios, one for MORB at $\sim 1350^{\circ} \mathrm{C}$ and the other for hot mantle $\left(\mathrm{T}_{\mathrm{P}} \sim 1500^{\circ} \mathrm{C}\right)$ beneath thick continental lithosphere. In nature, increasing $\mathrm{T}$ results in melting at progressively higher $\mathrm{P}$ and numerous laboratory melting experiments on natural peridotite show that the $\mathrm{MgO}$ content of any melt is proportional to the temperature at which melting takes place and not the pressure of melting (e.g. Hirose and 
Kushrio, 1993; Walter, 1998; Hirschmann, 2000). According to Herzberg and O’Hara (2002), there is little change in $\mathrm{MgO}$ content of the ascending magma because P-T melting paths are approximately coincident with $\mathrm{T}-\mathrm{P}$ isopleths of $\mathrm{MgO}$ in liquids defined by olivine saturation surface. Therefore, for the cases shown in Fig. 4 all the melt formed at $1350^{\circ} \mathrm{C}$ will have 11.8 $\mathrm{wt} \% \mathrm{MgO}$ and all melt that formed at $1500^{\circ} \mathrm{C}$ will have $17.5 \mathrm{wt} \% \mathrm{MgO}$ regardless of the pressure of melting. Conversely, $\mathrm{SiO}_{2}$ increases and $\mathrm{FeO}$ decreases systematically with increasing pressure, covariations that are not directly related to temperature (Fig. 4). $\mathrm{CaO}$ varies little across a wide spectrum of melting conditions and is mainly controlled by the extent of melting with dilution of $\mathrm{CaO}$ occurring in large melt fractions (Herzberg and Asimow 2008). Fig. 4 shows the approximate geochemical variations expected for individual small melt droplets of $\sim 1 \%$ melt formed instantaneously at a given $\mathrm{P}$ and $\mathrm{T}$. The accumulative fractional melt (AFM) that combines to form the parental magma to the lava erupted at the surface will be made up of the integrated sum of these small melt droplets and will therefore not necessarily fall along the curves shown. Various authors (e.g. Klein and Langmuir, 1987; Hole and Saunders, 1996; Lee et al., 2009; Hole and Millett, 2016) offer methods for calculating a mean pressure of melting which is an estimate of the pressure of generation, and therefore composition, of the prevalent accumulative fraction melt which might be seen at the surface (Fig. 4). For melting at $\mathrm{T}_{\mathrm{P}} \sim 1500^{\circ} \mathrm{C}$ beneath thick lithosphere all the melt produced will have higher $\mathrm{FeO}$ and lower $\mathrm{SiO}_{2}$ than any of the melt formed at ambient $\mathrm{T}_{\mathrm{P}}$ at a spreading ridge. This also means that MORB will have higher $\mathrm{SiO}_{2} / \mathrm{FeO}$ than melts formed at $\mathrm{T}_{\mathrm{P}} \sim 1500^{\circ} \mathrm{C}$.

With knowledge of the $\mathrm{MgO}$ and $\mathrm{FeO}$ contents of the melt droplets we can estimate the variability in Fo content of olivine in equilibrium each melt droplet. This has been calculated using the pressure-sensitive method of Topliss (2005) and is shown in Fig. 4. For both melting domains of interest, olivine compositions overlap in the range Fo88.5-93.5, although the cooler domain has a slightly larger range of Fo. This means that all melts of mantle peridotite, regardless of melting temperature and pressure, will potentially crystallize olivine covering similar ranges in Fo content. For the overlapping range of Fo contents in Fig. 4 the temperature that would be derived using, for example, an olivine-melt thermometer, would be significantly lower for the MORB melting domain than the $1500^{\circ} \mathrm{C}$ melting domain because the $\mathrm{FeO}$ content of melt droplets formed in the MORB melting domain are systematically lower than for the $1500^{\circ} \mathrm{C}$ melt domain (Fig. 4).

Incomplete integration of melt throughout a melting domain may result in a range of magma compositions erupted at the surface. Melts formed at the shallowest, lowest pressure, and lowest temperature parts of the melting domain may not effectively integrate with much deeper, higher 
pressure melts, such that the same melting domain might produce magmas with variable $\mathrm{SiO}_{2}$, $\mathrm{FeO}$ and olivine Fo all of which formed at the same $\mathrm{T}_{\mathrm{P}}$. This also means that a range of olivine compositions might be expected in a single melt because olivine crystallization might take place over a range of pressures and temperatures in the melting domain. Once formed, olivine from a variety of depths would be with its host liquid and it still may be present in the final AFM. During this phase, melt decompresses and cools and olivines that crystallized at shallow depths are in equilibrium with colder melts. Therefore, the presence of ultra-magnesian olivine (Fo>91.5; Keiding et al., 2011) does not necessarily mean that crystallization occurred at high temperature but is more likely to reflect crystallization from a low-FeO, low-pressure melt, in the shallowest portion of a melting column (Keiding et al., 2011; Matthews et al., 2016). Accumulated fractional melts that formed at high temperatures beneath thin lithosphere, where the melting interval occurs over a large pressure range, should therefore contain a larger range in olivine compositions than a low-temperature melting domain in which melting took place over a limited pressure interval.

\subsection{Crystallization of primary magma}

A primary magma can be defined as a partial melt of a mantle lithology or lithologies that has been unmodified by any post-melting processes (Herzberg et al., 2007). Primary magmas are not seen at the surface because ascent of magma will be accompanied by cooling and crystallization. When a large enough volume of melt has been created that can separate from its source, it will be transported to some level in the lithosphere that is most likely a point of neutral buoyancy (Ryan, 1987; 1988). For thick continental lithosphere this might be at the Moho or somewhere within the deep continental crust. Alternatively, if plumbing allows, magma might be stored in shallow near-surface reservoirs. Consequently, a lava erupted at the surface will have a composition and mineralogy that reflects those of the accumulated fractional melts produced during decompression melting and any further modification that takes place during crystallization in a magma chamber within the lithosphere. Of specific interest to petrologists is the crystallization interval for olivine alone because olivine-melt equilibrium is temperaturedependent and therefore a useful thermometer. However, as we discuss below, this thermometer is only effective for melts on the olivine liquidus, and not after plagioclase or augite have joined join the crystallizing assemblage.

The predominant erupted compositions in the NAIP are tholeiites. The crystallization histories of tholeiitic magmas vary with the depth and therefore pressure at which crystallization takes place (e.g. Villiger, 2004; 2007; Whitaker et al., 2007). Here we use the Petrolog3 model 
(Danyuchevsky and Plechov, 2011) to simulate crystallization of primary magmas are variable pressures (Fig. 5). For magma stored close to the surface which undergoes crystallization at $\sim 0.5$ $\mathrm{GPa}$, olivine crystallizes first, and this is followed down-temperature by crystallization along the olivine + plagioclase cotectic and finally along the olivine + plagioclase + augite cotectic (Fig. 5). At pressures above $\sim 0.7 \mathrm{GPa}$, augite crystallizes before plagioclase feldspar, and the crystallization interval for augite expands at the expense of olivine as pressure increases (Fig. 5). Thus, if it were possible to store magma at $\sim 1.5 \mathrm{GPa}$, the amount of olivine crystallization that would take place before augite joined the crystallizing assemblage would be smaller than that for the same melt crystallizing close to the surface (Fig. 5). As a hypothetical example, we can consider a primary magma formed at $\mathrm{T}_{\mathrm{P}} \sim 1500^{\circ} \mathrm{C}$ from melting of peridotite such as the model primary magma to Baffin Island picrite BI/DI/22 given in Hole and Millett (2016). This model primary magma was generated by decompression melting from 3.8-1.6 GPa, representing a melt-fraction of 0.27 and it contains $17.5 \mathrm{wt} \% \mathrm{MgO}$ and $9.8 \mathrm{wt} \% \mathrm{FeO}$ (Herzberg and O'Hara 2002; Herzberg and Asimow, 2008; 2015; Hole and Millett, 2016). If this magma crystallized at near-surface pressure, olivine Fo91.4 would crystallize at $\sim 1400^{\circ} \mathrm{C}$ and crystallization of olivine of progressively lower Fo content would continue until $\sim 1200^{\circ} \mathrm{C}$ at which stage the melt would contain $\sim 8.5 \mathrm{wt} \% \mathrm{MgO}$ and would be in equilibrium with olivine Fo83.5. At this point plagioclase would join the crystallizing assemblage and thereafter, crystallization would take place along the $\mathrm{L}+\mathrm{Ol}+\mathrm{Pl}$ cotectic. The total temperature range over which olivine crystallized would be $\sim 1400-1200^{\circ} \mathrm{C}$ (Fig. 5). For crystallization of the same magma at $\sim 1.5 \mathrm{GPa}(\sim 50 \mathrm{~km}$ depth) augite would begin to crystallize at $\sim 11.5 \mathrm{wt} \% \mathrm{MgO}$ and $\sim 1370^{\circ} \mathrm{C}$ when the magma would in equilibrium with olivine Fo87.5 (Fig. 3). This leaves a considerably smaller range in composition and temperature of olivine crystallization than at $0 \mathrm{GPa}$. For a MORB primary magma with $11.5 \mathrm{wt} \% \mathrm{MgO}$ (Herzberg and Asimow, 2015) crystallizing at $0 \mathrm{GPa}$, initial olivine crystallization (Fo 90.5) occurs at $\sim 1270^{\circ} \mathrm{C}$ and plagioclase joins liquidus at $\sim 1226^{\circ} \mathrm{C}$ and Fo 88.8 providing little opportunity for lavas that have only crystallized olivine to be erupted.

For magmatic systems that were dominated by low pressure fractional crystallization the probability of finding lavas that crystallized olivine alone is much greater than for magmatic systems dominated by high pressure fractional crystallization. This also means that attempts to generate useful temperature information are thwarted if magmas crystallize at considerable depth in the crust. Some NAIP magma systems, and particularly those which are associated with thick continental lithosphere such as the British Palaeocene Igneous Province (BPIP), are dominated by basalts that crystallized at $>0.9 \mathrm{GPa}$ (Hole et al., 2015a; Hole, 2018) and the early crystallization of augite makes any attempts to generate temperature information extremely 
difficult. Consequently, most available temperature data are biased towards magmatic systems that crystallized at low pressures. The extensive L+Ol crystallization interval for melts produced at high temperatures and crystallizing at low pressures is often considered to be one of the most important mechanisms for producing the large volumes of high-MgO picritic lavas such as those seen throughout the NAIP and particularly in West Greenland. However, other mechanisms, perhaps not requiring high temperatures, can contribute to the generation of picrite, as we now discuss.

\subsection{The origin of picrite}

The reader is referred to Appendix 1 for detailed petrographical and petrogenetic discussions on the origin of picrites from the NAIP, and in this section we focus on the key points pertinent to obtaining temperature estimates from such lithologies.

Picrite is defined by the IUGS classification (Le Bas, 2000; Le Maitre et al., 2002) as possessing $>12 \mathrm{wt} \% \mathrm{MgO}, 30 \mathrm{wt} \%<\mathrm{SiO}_{2}<52 \mathrm{wt} \%$ and $<3 \%$ total alkalis. Kerr and Arndt (2001) noted that this classification is limited in the sense that textural and mineralogical criteria are largely ignored. For example, samples which may conform to the IUGS criteria do not necessarily contain only olivine; many have augite or titanaugite as well (the picrites of the ankaramite type of Macdonald, 1949). Furthermore, an olivine-phyric lava formed by minor crystal accumulation from a silicate liquid magma with $11 \mathrm{wt} \% \mathrm{MgO}$ would also be classified as a picrite even though it is not related directly to a high $\mathrm{MgO}(>12 \mathrm{wt} \%)$ and therefore high T liquid composition. The following discussion is confined to some pertinent considerations as to the origin of picrites in general.

Accumulation of olivine is likely to be a common magma chamber process which results in the eruption olivine-laden lavas with high $\mathrm{MgO}$ content, but this does not necessarily mean that such lavas are related to a high-MgO primary magma composition. Indeed, samples of liquid compositions in the form of pillow lava glasses from Disko Island and Baffin Island contain $<10 \mathrm{wt} \% \mathrm{MgO}$ (Larsen and Pedersen, 2000; Francis et al., 1985) whereas whole-rock analyses of the same samples show that they are picrites containing up to $22 \mathrm{wt} \% \mathrm{MgO}$ (Appendix 1 , section 1.2). Additionally, olivine in these samples is not in equilibrium with the host glass, a feature that is also characteristic of many Icelandic high $\mathrm{MgO}$ lavas (Thompson and Maclennan, 2011). This implies that olivine accumulation is an important process in the petrogenesis of these high $\mathrm{MgO}$ lavas. There is, therefore, no simple relationship between the $\mathrm{MgO}$ content of a whole-rock analysis and $\mathrm{T}_{\mathrm{P}}$.

Most lavas do not crystallize as convenient mixtures of chilled liquid (glass) and 
phenocrysts but are holocrystalline and contain olivine phenocrysts in a crystalline groundmass. Therefore, olivine and glass compositions can rarely be directly compared. However, it is also true that lavas with a fine-grained groundmass have typically the same composition as a glass, and in such cases comparison between groundmass and olivine phenocrysts may be possible. Another important scenario is the possibility of the generation of large volumes of near crystalfree magma by accumulation of phenocrysts onto the floor and walls of a magma chamber. In this case, the liquid might have formed by crystallization along a cotectic but may not contain any phenocrysts to suggest such an origin. If such a liquid was then to interact with accumulative olivine from another source within the magmatic system, the result would be a picrite that was made up of a mixture of moderately evolved liquid plus olivine that was not derived directly from the same batch of magma. The resultant magma would carry little or no olivine that was in equilibrium with its host liquid, and the whole-rock analysis would be one of a cumulate.

Whether olivine accumulation takes place in sufficient volume to produce a picrite from a lower MgO melt depends on magmatic plumbing. Thomson and Mclennan (2011) have shown that in Iceland melts may pass through a crystal mush formed by accumulation of dominantly olivine but also of augite and plagioclase, and that interaction between fresh magma and crystal mush results in the eruption of lavas with olivine that is not in equilibrium with the carrier glass. In the case of Skye in the British Palaeocene Igneous Province (BPIP), minor picritic dykes intrude the Cuillin gabbro carapace at about the level of cumulus peridotite and are exposed particularly to the south and west of the intrusion. Many picritic dykes have large olivine phenocrysts concentrated in the middle of the dikes, and thus, are the type examples of flowage differentiation (e.g., Harker, 1908; Drever and Johnston, 1959). The dike margins are fine grained and without much olivine. The dikes evidently intruded soft and hot gabbro, troctolite, and layered peridotite, probably containing some interstitial melt; they acquired olivine from these lithologies, ultimately a picritic dyke interior.

Through the study of a series of historic eruptions, Wright and Fiske (1971) documented extensive mixing between magmas arriving at a cauldron or 'staging area' just beneath the summit of Kilauea, Hawaii, with other magmas stagnating and differentiating along the Kilauea East Rift. The physical reason for existence of the staging area $3 \mathrm{~km}$ below the summit is that ascending magmas, buoyant at first, encounter a region where the density of the country rocks (formation density) is determined by fracture porosity and spaces between lava flows and within them. At that depth, usually $2-4 \mathrm{~km}$, the formation and magma density match, the magma is no longer buoyant, and further inflation simply forces the magma sideways into a region of neutral 
buoyancy in lateral rift zones (e.g., Ryan, 1987; 1988). Eruption occurs when inflation rates exceed the capacity of the summit magma reservoir, and the lateral rift zones can no longer accommodate the rate of magma supply. At points of least lithostatic load, lateral flank eruptions occur. One consequence of this magma transport system is that, when magma reaches the region of neutral buoyancy, most olivine is shed from it before it can even begin to ascend again. Thus, most olivine accumulates in cumulus dunite masses far below ground level (e.g., Clague and Denlinger, 1994).

Repeated eruption of large volumes of picrite on the land surface, as occurred in West Greenland and the Coast of Baffin Island, suggests that regions of neutral buoyancy did not exist in the crust at these locations. The geology of both regions is essentially that of Archaean mantle cratons and later Proterozoic granitic intrusions with associated metamorphic rocks. Apart from the Tertiary rift basin that now forms the Labrador Sea, these represent peneplains that were originally mountain systems that were eroded nearly flat (Davis, 1889, as reformulated by Fairbridge and Finkl, 1980). The exposed rocks of this ancient surface are almost entirely massive crystalline granitoids and high-grade metamorphic rocks that for aeons contained no remnant regions of fractured, porous rock, or thick, loosely consolidated sediment. In such rock, magma-chamber systems such as those of the active volcanoes of Hawaii or the ocean crust apparently could not and did not develop. Stripping away of all rock with significant formation porosity means that, during later continental rifting, primitive magma was able to ascend from mantle depths without significantly stagnating in crustal staging areas. Magma ponding in shallow regions of neutral buoyancy did not occur, thus extended differentiation did not take place. Basalt dikes penetrating cold Archaean granite are therefore not likely to react significantly with granitic materials if passage through them is quick and the volume of transiting basalt is large. Mainlining of-near mantle sources, not high melting temperatures, thus is responsible for the abundance of picrites of West Greenland and Baffin Bay.

The differences in magmatic plumbing and crustal structure between locations such as Iceland rift zones, where no ancient metamorphic basement is present, and West Greenland, may have significantly influenced the ability to erupt picrite at the surface, without necessarily requiring significant variation in $\mathrm{T}_{\mathrm{P}}$.

\section{The olivine-melt and olivine-spinel equilibrium thermometers for volcanic systems.}

Melting experiments aimed at understanding olivine-liquid equilibrium were developed about half a century ago (Roeder and Emslie, 1970). Since that time, the technique has been refined (e.g. Beattie et al., 1991; Beattie, 1994; 1995; Putirka, 2008b) and it remains one of the 
mainstays of estimating temperatures of the crystallization of basaltic magmas. The technique relies on attainment of near-equilibrium conditions between olivine and melt in natural magmatic systems, a condition that is rarely satisfied because most olivine-phyric lavas contain olivine with a range of compositions (Appendix 1). A more recent development in thermometry, which does not require any knowledge of the composition of the lava sample itself, utilizes the equilibrium between olivine and chrome spinel (e.g. Coogan et al., 2012; Matthews et al., 2016; Spice et al., 2016). This method, often known as the Al-in olivine geothermometer, relies on the temperature-dependent exchange of $\mathrm{Al}_{2} \mathrm{O}_{3}$ between the two phases to generate a temperature estimate ( $\left.\mathrm{T}_{\mathrm{Ol}-\mathrm{Sp}}\right)$. Again, attainment of equilibrium between olivine and spinel must be demonstrated or assumed but there is no necessity to demonstrate equilibrium between olivine and the whole-rock. Here we summarize some of the applications of olivine-melt and olivinespinel thermometry to NAIP lavas.

\subsection{Olivine-melt equilibrium temperature estimates.}

Putirka (2008b) provides a detailed account of the methods and applications of olivine-melt thermometers, and the reader is referred to that work for details of the methodology. Because olivine is one of the first minerals to crystallize from a mafic liquid at low pressures $(<0.5 \mathrm{GPa})$ olivine-based thermometers have the potential to record the highest temperature in a system. If the temperature at which olivine crystallized can be determined, the P-T conditions of melting can be constrained and the composition of the primary magma that is ancestral to the lava erupted at the surface can be estimated.

The olivine-melt thermometer requires equilibrium to have been attained between olivine and host liquid. Establishing attainment of equilibrium rests with knowledge of the partitioning of iron and magnesium between olivine and melt $\left(K_{\mathrm{D}(\mathrm{Fe}-\mathrm{Mg})}{ }^{\mathrm{Ol}-\mathrm{melt}}\right)$ and the value of $K_{\mathrm{D}(\mathrm{Fe}-\mathrm{Mg})}{ }^{\mathrm{Ol}-}$ melt has been determined as $0.30 \pm 0.03$ for crystallization at $0 \mathrm{GPa}$ (Roeder and Emslie, 1970; Beattie et al., 1991; Herzberg and O'Hara, 2002). For any mafic liquid crystallizing at $0 \mathrm{GPa}$, the $\mathrm{Mg} / \mathrm{Fe}$ (cationic ratio of $\mathrm{Mg}^{2+} / \mathrm{Fe}^{2+}$ ) of the melt will therefore be $0.3 \pm 0.03$ times that of the $\mathrm{Mg} / \mathrm{Fe}$ of an olivine phenocryst in equilibrium with that melt. Toplis (2005) provides a thermodynamically robust model for determining $K_{\mathrm{D}(\mathrm{Fe}-\mathrm{Mg})}{ }^{\text {Ol-melt }}$ at pressures that are likely to be encountered during mantle melting, thus allowing temperatures estimates for the generation of primary magmas at depth to be made (Herzberg and O'Hara, 2002; Matzen et al., 2017; Hole, 2018).

Conventionally, olivine-liquid equilibria are represented by plotting the $\mathrm{Mg} \#$ of the liquid (molecular $\mathrm{Mg} /\left[\mathrm{Mg}+\mathrm{Fe}^{2+}\right]$ ) against the forsterite content $(\mathrm{Fo})$ of the component olivine on a 
Rhodes diagram (Fig. 6a and b) named after its creator, J. Michael Rhodes (Rhodes et al., 1979). Olivine in equilibrium with it host liquid will fall along the solid curve in Fig. 6a, the two dotted lines representing the experimental uncertainty of \pm 0.03 in $\mathrm{k}_{\mathrm{D}(\mathrm{Fe}-\mathrm{Mg})} \mathrm{Ol} / \mathrm{L}$. Additionally, if the olivine and host liquid are in equilibrium, then olivine should also be in equilibrium with the measured $\mathrm{Mg} / \mathrm{Fe}$ of the whole-rock. Once a case for equilibrium has been established, there are several published calculation methods for estimating crystallization temperature (e.g. Putirka, 2008) which rely on understanding the saturation conditions of olivine in a melt for a given melt composition at a given temperature. For olivine and glass pairs that do not fall within the uncertainty envelope in Fig. 6a, the case for equilibrium is not established and a temperature determination is not warranted, or at least should not be attempted. Chilled basaltic glass is the best material to use to give a representative composition of a liquid and therefore olivine vitrophyric samples are ideal for this purpose but still requires that olivine is in equilibrium with the host glass. Such samples are not abundant naturally, and in most cases vitrophyric glasses are found in the chilled margins of pillow lavas that were quenched in water. Porphyritic finegrained, but totally crystalline lavas may also be used, but if there has been any accumulation of olivine in the then such samples are unlikely to pass the equilibrium test. Petrolog3 (Danyuchevsky and Plechov, 2011) forward crystallization models illustrating the relationship between Fo content of olivine and $\mathrm{T}_{\mathrm{Ol}}$ during crystallization of some liquids generated in melting experiments (Walter, 1998) are is shown in Fig. 6c. During the crystallization of olivine alone, the covariation between $\mathrm{Fo}_{\mathrm{O}}$ and $\mathrm{T}_{\mathrm{Ol}}$ is steep and positive, but as soon as plagioclase joins the crystallizing assemblage the curve flattens and $\mathrm{T}_{\mathrm{Ol}}$ determinations will vary little for a large variation in Fo (Fig. 6c). The consequence of this is that estimates of $\mathrm{T}_{\mathrm{Ol}}$ are only effective in magmas that have crystallized olivine alone, that is, magmas that lie along the olivine liquidus. Olivine and glass analysed by electron microprobe for samples from pillow basalts from Kistufel, Iceland (Breddam, 2002) are nearly at equilibrium (Fig. 6b), and using equation [4] of Putirka et al. (2007) produce olivine crystallization temperatures of $1226 \pm 26^{\circ} \mathrm{C}$.

However, for the same samples with host glass and the component olivine analysed as a whole-rock data shift toward the right in Fig. $6 \mathrm{~b}$ and away from the line for equilibrium. The whole-rock samples therefore have a higher $\mathrm{Mg \#}$ than that required by their component olivine - a clear indication of olivine accumulation (Putirka, 2008b). For three samples from Kistufel, olivine, glass and whole rocks all approximate to equilibrium and yield an average $1243 \pm 37^{\circ} \mathrm{C}$. Olivine and host glasses from Herdubreidatogl, Iceland (Thomson and Maclennan, 2011) exhibit a close approximation to equilibrium and yield two different temperature populations with $\mathrm{T}_{\mathrm{Ol}}=1235 \pm 25^{\circ} \mathrm{C}$ and $1297 \pm 10^{\circ} \mathrm{C}$ although there is evidence of minor olivine accumulation 
in some samples. In contrast, olivine-phyric glasses from Borgarhraun, Iceland (Thomson and Maclennan, 2011) contain olivine with Fo contents that are 2-3 mol\% higher than that expected for equilibrium with their carrier liquids. Thomson and Maclennan (2011) attributed this to a multi-stage process involving local diffusion which acts to homogenize single olivine crystals in a crystal mush, coupled with alteration to the full thickness of a mush pile by diffusion through the interstitial melt phase. Supporting evidence for this process came from internal dislocation alignment features and undulating extinction positions in some olivine 'phenocrysts' which were potentially formed by accumulative processes. Direct evidence for the existence of crystal mush beneath Icelandic volcanoes was also seen in mush xenoliths included in eruptive products. The overall result is that the majority of olivines in Icelandic lavas are not in equilibrium with their carrier liquids and they do not yield useful temperature information. A similar result is also apparent in data for olivine-phyric pillow lavas from Baffin Island and Disko Island, West Greenland, (Fig. 6b; Appendix 1). Olivine and whole-rock data from both locations exhibit clear signs of olivine accumulation, and Baffin Island pillow glasses contain olivine with Fo contents 1-4 mol\% higher than the carrier liquid. For Disko Island pillow lavas the situation is even more extreme with some olivine having up to $8 \mathrm{~mol} \%$ higher Fo than that expected for the carrier liquid. Disequilibrium between olivine and glass or whole rocks thus is the norm rather than an exception.

Converting $\mathrm{T}_{\mathrm{Ol}}$ to $\mathrm{T}_{\mathrm{P}}$ is not trivial and requires assumptions to be made about the extent and pressure of melting (Putirka et al., 2007). Consequently, the conventional use of $\mathrm{T}_{\mathrm{Ol}}$ data is to compare results for the lava of interest with data for MORB glasses containing olivine with a similar Fo assuming $\mathrm{T}_{\mathrm{P}}$ for MORB is $\sim 1350^{\circ} \mathrm{C}$. Using the olivine thermometer of Putirka et al. (2007) the highest $\mathrm{T}_{\mathrm{Ol}}$ that can be obtained for Herdubreidatogl is $\sim 1297^{\circ} \mathrm{C}$ for a sample in equilibrium with Fo 87.6 . A MORB glass with the same Mg\# in equilibrium with the same olivine composition would yield $\mathrm{T}_{\mathrm{Ol}} \sim 1170^{\circ} \mathrm{C}$ but would have substantially less $\mathrm{FeO}$ in the whole rock because MORB is formed at a lower mean pressure than Icelandic basalts (Matthews et al., 2016). The value of $\Delta \mathrm{T}$ is then used to imply that the mantle potential temperature for the generation of the lavas at Herdubreidatogl was $135^{\circ} \mathrm{C}$ hotter than for MORB giving $\mathrm{T}_{\mathrm{P}}=1485^{\circ} \mathrm{C}$. However, the cooler $\mathrm{T}_{\mathrm{Ol}}$ population at Herdubreidatogl would suggest $\Delta \mathrm{T}+40^{\circ} \mathrm{C}$. For Kistufel, at Fo87.9, $\mathrm{T}_{\mathrm{Ol}} \sim 232$ and for MORB at Fo87.9 $\mathrm{T}_{\mathrm{Ol}} \sim 1217$ giving $\Delta \mathrm{T}+15^{\circ} \mathrm{C}$. For various reasons the highest $\mathrm{T}_{\mathrm{Ol}}$ estimates tend to be the ones that make their way into the literature. Matthews et al. (2016) have provided a justification for using the highest temperature estimates based on the proposal that during the ascent of melt in the upper mantle, melts formed 
in deeper parts of the melting domain will yield higher temperatures than those formed at lower pressures and closer to the top; incomplete homogenization of deep and shallow melt produces a variation in apparent $\mathrm{T}_{\mathrm{P}}$ at any one location and even in individual samples.

Olivine-melt thermometry, whilst being a rigorous thermodynamical methodology, suffers from a lack of natural samples that fall on the olivine liquidus and for which olivine-melt equilibrium can be established with a certain degree of approximation. Additionally, significant difficulties in translating $\mathrm{T}_{\mathrm{O}}$ into the more useful mantle estimates of potential temperature make data open to interpretation. For this reason, olivine melt thermometry is generally used in addition to other methods of temperature estimation such as the olivine-spinel method of equilibration, discussed below.

\subsection{Olivine-spinel-melt equilibration temperatures - $T_{\text {Ol-Sp (aluminium-in-olivine) }}$}

This method of determining crystallization temperatures is attractive because it does not require knowledge of the whole-rock composition but relies on the partitioning of $\mathrm{Al}_{2} \mathrm{O}_{3}$ between olivine and spinel, which has been demonstrated experimentally to be dependent on temperature of crystallization and the chromium number of spinel (Cr\# - molecular $100 \mathrm{Cr}_{2} \mathrm{O}_{3} /\left(\mathrm{Cr}_{2} \mathrm{O}_{3}+\mathrm{Al}_{2} \mathrm{O}_{3}\right)$.

If olivine contains inclusions of early-crystallized chrome-spinel with which it is in equilibrium, a temperature determination can be made using mineral pairs. Olivine and chromite both form very early in the crystallization sequence of primitive basalts, perhaps within a few tens of degrees of the primitive-basalt liquidus, providing the melts were extracted from a Cr-spinel-bearing source region (Coogan et al., 2014). However, Trela et al. (2017) note that spinel typically crystallizes at lower temperatures than olivine and that the spinel liquidus shifts to higher temperatures with increasing pressure. The spinel crystallization model of Ariskin and Nikolaev (1996) does not predict L+Ol+Sp until after around 15\% olivine fractionation of a model primary magma with $\sim 17.5 \mathrm{wt} \% \mathrm{MgO}$. Nevertheless, sufficient petrographical data exist to suggest that magnesian olivine with Fo 90 contains inclusions of Cr-spinel (e.g. Spice et al., 2016; Trela et al., 2017), and this is supporting evidence for early spinel crystallization in picritic magmas (e.g. Coogan et al., 2014).

The partition coefficient for $\mathrm{Al}_{2} \mathrm{O}_{3}$ between spinel and coexisting olivine $\left(\mathrm{K}_{\mathrm{D}}\right.$ $\mathrm{Al}_{2} \mathrm{O}_{3} \mathrm{Sp} / \mathrm{Al}_{2} \mathrm{O}_{3} \mathrm{Ol}$ ) for olivine and spinel pairs from Baffin Island varies from $\sim 0.0058$ to $\sim 0.0022$. This range together with $\mathrm{Cr} \# 54.8-64.8$ of the spinel $(\mathrm{Cr} \#=\mathrm{mol}[\mathrm{Cr} / \mathrm{Cr}+\mathrm{Al}])$ giving $\mathrm{T}_{\mathrm{Ol}-\mathrm{Sp}}$ $=1240-1461^{\circ} \mathrm{C}\left(\right.$ Spice et al., 2016). The $\mathrm{Al}_{2} \mathrm{O}_{3}$ content of olivine is generally $<0.11 \mathrm{wt} \%$ and detection limits for analysis using a modern electron microprobe are $\sim 0.004 \mathrm{wt} \%$ as long as a 
long counting time strategy is employed during analysis (Coogan et al., 2012; Spice et al., 2016). Consequently, the careful high-precision analysis and attention to uncertainties that are now possible are integral facets of the technique. In addition, oivine and spinel are assumed to be in equilibrium, and unlike the olivine-glass method where a Rhodes diagram can be employed to help establish this, there is no simple chemical test for equilibrium between spinel and olivine. The practice for estimating $\mathrm{T}_{\mathrm{P}}$ is by comparison with $\mathrm{T}_{\mathrm{Ol}-\mathrm{Sp}}=1193^{\circ} \mathrm{C}$ for $\mathrm{MORB}$ for Fo 91 (Coogan et al., 2014). Such determinations for NAIP lavas from Baffin Island yield average $\Delta \mathrm{T}=+207^{\circ} \mathrm{C}$ (Spice et al. 2016), for zero age Icelandic basalts average $\Delta \mathrm{T}=+132^{\circ} \mathrm{C}$ (Matthews et al., 2016) suggesting $\mathrm{T}_{\mathrm{P}} \sim 1550^{\circ} \mathrm{C}$ for Baffin Island and $\mathrm{T}_{\mathrm{P}} \sim 1480^{\circ} \mathrm{C}$ for present-day Iceland, estimates that are consistent with those derived from other petrological models (e.g. Herzberg and Asimow, 2015; Hole and Millett, 2016; Matthews et al., 2016).

None of the studies on NAIP lavas that utilize olivine-spinel equilibria have considered in detail the composition of $\mathrm{Cr}$-spinel used in the method and the additional information that such data might provide. Here, and in appendix A1, we address this issue. Fig. 7 illustrates the composition of Cr-spinel in NAIP lavas and from other locations for which $\mathrm{T}_{\mathrm{Sp}-\mathrm{Ol}}$ data are available. Also shown are the range of compositions of Cr-spinel that would crystallize from a range of model primary magmas from the same locations, as derived using PRIMELT3 (Herzberg and O'Hara, 2002; Herzberg and Gazel, 2009; Hole and Millett, 2016; Trela et al., 2017) using the spinel crystallization model SPINMELT-2.0 (Nikolaev et al.,2018). Cr-spinel in Gorgona komatiites have $\mathrm{Mg} \#$ up to 80 coupled with $\mathrm{Cr} \#$ 50-60 and as such are the most primitive in the data set and fall within the region for predicted $\mathrm{Cr}$-spinel compositions crystallizing from near-primary magma compositions (Fig. 7); a similar observation can be made for Cr-spinel in MORB tholeiites from the Siqueiros Fracture Zone (Herzberg and Azimow, 2015). Ranges in Mg\# for BPIP and Baffin and Disko island samples are large $(<40$ to $~ 70$ ) and only those with the highest Mg\# resemble spinels in primary magmas. Spinel in Icelandic basalts exhibit a broadly positive correlation between $\mathrm{Mg \#}$ and $\mathrm{Cr} \#$ but none of the Cr-spinels falls close to that expected from a primary magma composition. The importance of these covariations between $\mathrm{Mg \#}$ and $\mathrm{Cr} \#$ is that $\mathrm{Cr}$-spinel with the highest $\mathrm{Mg \#}$ from any group of samples yields the highest crystallization temperatures.

Fig. 8a shows Cr-spinel crystallization temperature $\left(\mathrm{T}_{\mathrm{Sp}}\right)$ versus $\mathrm{Cr} \#$ of spinel for model primary magma compositions using the SPINMELT-2.0 simulation of Nikolaev et al., (2018) and the model primary magmas given in Hole and Millett (2016). The temperature of spinel crystallization is strongly dependent on the $\mathrm{Cr}_{2} \mathrm{O}_{3}$ content of it host primary magma, which is linked to the amount of Cr-diopside entering the melt. Because of the difficulties in inverse 
modelling of the $\mathrm{Cr}_{2} \mathrm{O}_{3}$ abundances from lava compositions which have crystallized olivine + Cr-spinel, we have used model primary magmas derived from PRIMELT3 (Herzberg and Gazel, 2009; Herzberg and Asimow, 2015; Hole and Millett, 2016; Trela et al., 2017) and calculated Cr-spinel compositions over a range of reasonable magma $\mathrm{Cr}_{2} \mathrm{O}_{3}$ abundances (Fig. 8). Fig. $8 \mathrm{~b}$ shows $\mathrm{T}_{\mathrm{Ol}-\mathrm{Sp}}$ calculated from electron probe data on rock samples versus measured spinel compositions.

A key feature of Fig. 8 is that SPINMELT2.0 predicts $\mathrm{T}_{\mathrm{Sp}}$ which is around $100^{\circ} \mathrm{C}$ cooler than determined $\mathrm{T}_{\mathrm{Ol}-\mathrm{Sp}}$ for samples from Tortugal, Baffin Island, Disko Island and the BPIP whereas for Gorgona and Iceland, predicted and measured temperatures cover similar ranges. However, for all samples, SPINMELT2.0 predicts the same range of $\mathrm{Cr} \#$ as the analytical data. These apparent temperature discrepancies cannot be accounted for simply by underestimating the $\mathrm{Cr}_{2} \mathrm{O}_{3}$ content of the primary magma because increasing $\mathrm{Cr}_{2} \mathrm{O}_{3}$ will increase both $\mathrm{Cr} \#$ and $\mathrm{T}_{\mathrm{Sp}}$. For BPIP picritic lavas, natural $\mathrm{Cr}$-spinels in give higher $\mathrm{T}_{\mathrm{Ol}-\mathrm{Sp}}$ and have lower $\mathrm{Cr} \#$ number than those predicted from the primary magma compositions. Decreasing Cr\# but with little change in Tol-sp can be caused by crystallization at pressure $>1 \mathrm{~atm}$. Many BPIP magmas underwent polybaric fractionation at pressures up to $1.6 \mathrm{GPa}$ (e.g. Thompson, 1974; 1982; Thompson et al., 1980; 1986; Hole, 2018), with many of them equilibrating at $\sim 0.9 \mathrm{GPa}$. Consequently, the lower Cr\# in the natural Cr-spinels for Mull and Skye are explained readily by crystallization at $\sim 1.0 \mathrm{GPa}$ (Fig. $8 \mathrm{~b}$ ). Whereas the temperature discrepancy between predicted $\mathrm{T}_{\mathrm{Sp}}$ and $\mathrm{T}_{\mathrm{Ol}-\mathrm{Sp}}$ determinations might result from underestimation of the $\mathrm{Cr}_{2} \mathrm{O}_{3}$ content of the BPIP model primary magmas, a primary magma containing up to $0.50 \mathrm{wt} \%$ is required to attain the measured values of $\mathrm{T}_{\mathrm{Ol}-\mathrm{Sp}}$. Notably, the hottest, largest melt fractions derived from dry mantle peridotite have the highest $\mathrm{Cr}_{2} \mathrm{O}_{3}$ content (Herzberg and O'Hara, 2002) and picrites from Tortugal contain $\sim 0.47 \mathrm{wt} \% \mathrm{Cr}_{2} \mathrm{O}_{3}$. Whether the BPIP picrites had a similarly high $\mathrm{Cr}_{2} \mathrm{O}_{3}$ content is a matter of conjecture.

Natural Cr-spinel in Icelandic basalts falls into two clusters with differing Cr\# (50-60 and $<45)$ but a similar range of TOl-Sp $\left(1250-1400^{\circ} \mathrm{C}\right)$. The variability in $\mathrm{Cr} \#$ in natural samples is consistent with variable pressure of crystallization, the spinel with the lowest Cr\# crystallizing at $\sim 1.0 \mathrm{GPa}$ (Fig. 8). Similar estimates of pressure of crystallization for lavas from Theistareykir (Iceland) have been independently obtained (Maclennan et al., 2003; Hole, 2018). Consequently, once pressure of crystallization is accounted for, $\mathrm{T}_{\mathrm{Ol}-\mathrm{Sp}}$ and $\mathrm{Cr} \#$ for Icelandic lavas are consistent with model Cr-spinel compositions and crystallization temperatures.

In conclusion, simulations of Cr-spinel crystallization temperatures for Gorgona komatiies, Tortugal picrites, and Icelanic basalts are in broad agreement if the effects of pressure of 
crystallization are accounted for. For Baffin and Disko island picrites, the situation is less clear, and $\mathrm{T}_{\mathrm{Ol}-\mathrm{Sp}}$ are higher than $\mathrm{T}_{\mathrm{Sp}}$ by around $100^{\circ} \mathrm{C}$. For BPIP picrites spinel crystallized at up to $\sim 0.8 \mathrm{GPa}$, but again $\mathrm{T}_{\mathrm{Ol}-\mathrm{Sp}}$ are higher than $\mathrm{T}_{\mathrm{Sp}}$ by $\sim 100^{\circ} \mathrm{C}$. This also means that published $\mathrm{T}_{\mathrm{P}}$ data for Baffin Island and Disko Island picrites and BPIP lavas based on this method may be too high. The reasons for these disparities in temperature estimates is likely to be the incorrect assumption that olivine and spinel are in equilibrium.

\section{Petrological methods of estimating mantle potential temperature}

The olivine-melt and olivine-spinel equilibrium thermometers are necessarily limited in their application to samples that satisfy specific mineralogical and thermodynamic criteria, but of which there are few in nature. This has led petrologists (e.g. Putirka, 2008; Herzberg and O'Hara, 2002; Lee et al., 2009; Herzberg and Asimow, 2008; 2015) to use the extensive compositional data base available from melting experiments on peridotite to generate theoretical melting models. These models generally involve subtraction or addition of olivine to lavas that are considered to have crystallized along the olivine liquidus, until a parental or primary magma composition is reached; this is determined either by the composition of olivine in the samples or data from melting experiments.

\subsection{Olivine addition and subtraction and estimates of primary magma compositions}

A common method used to estimate primary magma compositions is to add equilibrium olivine progressively in small increments (generally $0.5 \%$ ) to a lava analysis until the resultant model liquid is in equilibrium with the most $\mathrm{Mg}$-rich olivine which does not lie along a cotectic observed in the sample ('target olivine') and this model liquid is used as a proxy for a primary magma. This is often referred to as the 'olivine back-tracking method' (Fig. 9). For this procedure to be successful, the lava in question must have crystallized olivine alone in a closed system (no mixing allowed) and must not lie along a cotectic.

Identifying a target olivine composition is impossible in any sample containing a range of non-equilibrium olivine compositions. Nevertheless, there are published olivine crystallization temperature estimates that simply utilize the most Fo-rich olivine as the target olivine for backtracking to a primary magma composition (e.g. Larsen and Pederson, 2000; Thompson and Gibson, 2000). An example of the misleading temperature estimates that can be obtained this way are exemplified by data for picrites from the Etendeka province. Keiding et al. (2011) noted that olivine in Etendeka Province picrite JVT-09-32 (16.65 wt\% MgO, Mg\#=76.9) has a very large range of Fo contents (Figs 6 and 9; Fo86.6-93.3). For a target olivine of Fo93.3, the highest Fo 
olivine in the sample, back-tracking along an estimated olivine liquidus would yield a model primary magma containing $\sim 21 \mathrm{wt} \% \mathrm{MgO}$, equivalent to $\mathrm{T}_{\mathrm{P}} \sim 1590^{\circ} \mathrm{C}$ and would require the addition of $\sim 14 \%$ equilibrium olivine (magma 1 in Fig.9). This primary magma would fall close to the upper limits for compositions derived from melting experiments on mantle peridotite and would require a melt fraction in excess of $\sim 0.5$ (Herzberg and O'Hara, 2002) rendering it an unlikely composition. Performing the same calculation with target olivine Fo92.0 would suggest a primary magma formed at $\mathrm{T}_{\mathrm{P}} \sim 1500^{\circ} \mathrm{C}$ (magma 2 in Fig. 9), which would fall within the ranges for melting experiments. Olivine-hosted melt inclusions in JVT-09-32 have $\mathrm{MgO}$ in the range 13.5-17.2 wt \% but with low $\mathrm{FeO}=5.5-13.5$ wt\% (Mg\# 66.5-83.4). Keiding et al. (2011) proposed that the melt inclusions represented small samples of melt that are trapped in olivine at the time of its crystallization and are therefore micro- samples of the melting domain. The lowest $\mathrm{FeO}$ melt inclusions would be in equilibrium with olivine Fo94 which is the highest Fo content of olivine present in the lava (Fig. 9) whereas the highest FeO inclusions would be in equilibrium with Fo92.5. Keiding et al. (2011) attributed this to the effect of shallow melts failing to integrate with deeper melts in the melting region, and showed that the compositions of all melt inclusions and whole-rocks were consistent with generation from mantle peridotite at $\mathrm{T}_{\mathrm{P}} \sim 1520^{\circ} \mathrm{C}$.

Larsen and Pedersen (2000) used olivine back-tracking to generate model primary magma compositions by adding olivine to glassy rims of pillow lavas from Disko Island, and were able to derive $\mathrm{T}_{\mathrm{P}}$ up to $1550^{\circ} \mathrm{C}$. This incidentally, is consistent with $\mathrm{T}_{\mathrm{Ol}-\mathrm{Sp}}$ estimates. Olivine in Disko Island pillow glass \#400452 has compositions in the range Fo86.5-92.5 and the glass would be in equilibrium with olivine Fo85.6 require a model primary magma containing $18.6 \mathrm{wt} \% \mathrm{MgO}$ which formed at $\mathrm{T}_{\mathrm{P}} \sim 1530^{\circ} \mathrm{C}$, a composition that falls outside the range for experimental data (magma 4 in Fig. 9). However, the same calculation with a target olivine Fo91 would require addition of $\sim 19 \%$ olivine and yield $\mathrm{T}_{\mathrm{P}} \sim 1450^{\circ} \mathrm{C}$ and this time the primary magma composition would fall within the range of experimental melts (magma 5 in Fig 9). These apparent variations in $\mathrm{T}_{\mathrm{P}}$ generated for the pillow basalts are therefore simply a result of a choice of target olivine composition (see also Appendix 1).

Additional problems also arise if the crystallizing assemblage that led to the generation of a lava is poorly constrained or incorrectly assessed. Since identifying whether olivine has been the sole crystallizing phase or whether the melt was formed along the $\mathrm{L}+\mathrm{Ol}+\mathrm{Pl}$ cotectic is not simple, incorrect crystallization temperatures can be generated from cotectic liquids. For a MORB glass with 10.4 wt \% $\mathrm{MgO}$ and $7 \mathrm{wt} \% \mathrm{FeO}$ (Fig.9) containing equilibrium olivine phenocrysts (Fo89), and for a target olivine in equilibrium with mantle peridotite (Fo 90.5; Putirka, 
2008) a model primary magma would require $~ 5 \%$ olivine addition and contain $12.3 \mathrm{wt} \% \mathrm{MgO}$ requiring $\mathrm{T}_{\mathrm{P}} \sim 1350^{\circ} \mathrm{C}$, close to that expected for a MORB melting regime (black diamond in Fig. 8). For a MORB glass from the same location with $8.0 \mathrm{wt} \% \mathrm{MgO}$, which would be a cotectic liquid $(\mathrm{L}+\mathrm{Ol}+\mathrm{Pl})$, the same calculation gives $\mathrm{MgO} \sim 16.6 \mathrm{wt} \%, \mathrm{~T}_{\mathrm{P}} \sim 1480^{\circ} \mathrm{C}$, and would require addition of around $25 \%$ olivine to reach the primary magma composition (magma 3 in Fig. 9). Both these model primary magmas would fall within the region in Fig. 9 reserved for primary melts of mantle peridotite. Consequently, for fractional crystallization of any primary magma composition, liquids falling along a cotectic will always require apparently higher crystallization temperatures, higher $T_{P}$ and require more olivine addition to reach a primary magma composition than liquids from the same batch of magma which have olivine as the sole liquidus phase. Returning briefly to the Disko Island pillow glasses, an additional problem is that the steep trend the data exhibit on a plot of $\mathrm{FeO}$ versus $\mathrm{MgO}$ (Fig. 9) also implies that the glasses fall along the $\mathrm{L}+\mathrm{Ol}+\mathrm{Pl}$ cotectic. Consequently, in addition to the problem of determining the Fo content of the target olivine in these samples, the fact that the glasses fall along the $\mathrm{L}+\mathrm{Ol}+\mathrm{Pl}$ cotectic compounds the difficulties associated with estimating $\mathrm{T}_{\mathrm{P}}$ by this method.

As discussed earlier, olivine accumulation can result in picritic whole-rock compositions that may or may not have been derived by melting at elevated $\mathrm{T}_{\mathrm{P}}$. Consider the case of a MORB magma formed at $\mathrm{T}_{\mathrm{P}}=1350^{\circ} \mathrm{C}$ that has fractionated only olivine to give a glass with $\sim 9.5 \mathrm{wt} \%$ $\mathrm{MgO}$ which sits precisely at the end of the $\mathrm{L}+\mathrm{Ol}$ liquid line of descent (LLD). Accumulation of $30 \%$ olivine in the range Fo86-90 would give a whole-rock $\mathrm{MgO}$ content of $\sim 21 \mathrm{wt} \%$ (Fig. 9). Any attempt to subtract equilibrium olivine until a reasonable primary magma composition in equilibrium with, for example olivine Fo91 was reached, would result in a range of $T_{P}$ from $1397-1466^{\circ} \mathrm{C}$ depending on the Fo content of the accumulated olivine (Fig. 9). For a glass along the $\mathrm{L}+\mathrm{Ol}+\mathrm{Pl}$ cotectic with accumulated olivine the apparent $\mathrm{T}_{\mathrm{P}}$ would be even higher. Consequently, using olivine back-tracking can be fraught with problems and the results are frequently, if not always, unreliable.

\subsection{PRIMELT3 temperature estimates}

To address some of the issues with simple olivine back-tracking, Herzberg et al. (2007) and Herzberg and Asimow (2008; 2015) provided a development of the general principles but with some added rigorous petrological constraints on model primary magma compositions. PRIMELT3 software uses a mass-balance solution to the primary magma problem calibrated to fertile peridotite KR-4003, derived from a parameterization of experimentally determined partial-melt compositions (Herzberg and O’Hara, 2002; Herzberg, 2004; 2006; Walter, 1998). 
PRIMELT3 uniquely constrains the primary magma composition corresponding to given evolved lavas by computing a melt fraction that is common to both partial melts of mantle peridotite and to the primitive magmas from which the lava was derived. In this way, it differs from normal olivine back-tracking that use olivine composition alone to constrain primary magma composition and removes the difficulty of selecting the correct target olivine composition. For PRIMELT3, once a lava has been selected, equilibrium olivine is incrementally added to it until it reaches a composition within the melting interval of mantle peridotite in much the same way as for simple olivine back-tracking (Fig. 9). The composition of the model magma is then compared with melts generated during laboratory melting experiments until a common composition is found that matches both the model primary magma and experimental data. This is achieved by iteration, and any failure to produce a match of inverse and forward models is rejected and does not proved a model solution. Critical aspects of the PRIMELT model are that melts must have had olivine as the sole liquidus phase during crystallization and melt must have been derived from volatile-deficient peridotite. Lavas which show evidence of early augite crystallization are effectively identified from covariations between $\mathrm{MgO}$ and $\mathrm{CaO}$, because augite causes significant fractionation of $\mathrm{CaO}$ relative to $\mathrm{MgO}$, but olivine does not (Fig. 9b). It is not the same correlation as that produced by fractionation of olivine alone. For that reason, Hole and Millett (2016) suggest that any whole- rock composition with $<9.0 \mathrm{wt} \% \mathrm{MgO}$ should not be used because of the possibility of crystallization along the $\mathrm{L}+\mathrm{Ol}+\mathrm{Pl}$ cotectic.

As an illustration, of the 29 Etendeka samples reported by Keiding et al. (2011), 9 yield primary magma solutions using PRIMELT3 which have $\mathrm{MgO}=16.4-17.4 \mathrm{wt} \%$ and $\mathrm{T}_{\mathrm{P}}=1471$ $1497^{\circ} \mathrm{C}$. Inherent uncertainty in the model is $\pm 40^{\circ} \mathrm{C}$ (Herzberg and Asimow, 2015) and these $\mathrm{T}_{\mathrm{P}}$ estimates are therefore within uncertainty the same as those calculated by Keiding et al. (2011) from melt inclusion compositions. The 21 Etendeka samples that failed to yield model primary magma solutions did so because; i) lavas are identified as having fractionated augite; ii) lavas have insufficient $\mathrm{CaO}$ at a given $\mathrm{MgO}$ to have been derived from lherzolite and iii) lavas have insufficient $\mathrm{SiO}_{2}$ at a given $\mathrm{MgO}$ to have been derived from volatile-free peridotite. Full details of the methodology behind identifiying sample sin categories ii) and ii) above can be found in Herzberg and Asimow (2008). Using the standard olivine back-tracking procedure, no mechanism for identifying inappropriate model primary magma compositions exists and calculations rely only on the selection of target olivine of the correct composition.

A drawback with PRIMELT3 is that, just as with olivine-backtracking, the user must justify or assume that the lava in question was formed by crystallization of olivine alone from a primary 
magma composition. For example, PRIMELT3 cannot identify MORB glasses along the $\mathrm{L}+\mathrm{Ol}+\mathrm{Pl}$ cotectic and this can yield spurious $\mathrm{T}_{\mathrm{P}}$ data of up to $1480^{\circ} \mathrm{C}$. However, once augite joins the liquidus, PRIMELT3 recognizes its $\mathrm{MgO}-\mathrm{CaO}$ fractionation effects and does not yield primary magma estimates from such compositions (Fig. 9b). Additionally, the accumulation of olivine in a cotectic liquid that has previously crystallized augite is also recognized by PRIMELT3. Hole (2018) provides a detailed account of the difficulties of using PRIMELT3 when applied to polybaric fractional crystallization. . However, the accumulation of olivine in a glass formed along the $\mathrm{L}+\mathrm{Ol}+\mathrm{Pl}$ cotectic is still a challenge to recognise. In this connection, we have developed a simple method for of assessing whether lava or glass samples fall along the olivine liquidus which utilizes covariations between $\mathrm{Mg} \#$ and $\mathrm{MgO} / \mathrm{Al}_{2} \mathrm{O}_{3}$, the full details of which are given in Electronic Appendix 2. To illustrate, we turn to the example of Blafjall, Iceland.

Schiellerup (1995) identified four rocks series at Blafjall and analysed pillow-lava glasses and whole rocks for each series (Fig. 10). All glasses are identified as cotectic compositions using the $\mathrm{Mg} \#-\mathrm{MgO} / \mathrm{Al}_{2} \mathrm{O}_{3}$ diagram (Fig. 10 and Appendix 3) but 7 of the 29 glass samples yield apparent PRIMELT3 solutions with $\mathrm{T}_{\mathrm{P}}=1510 \pm 25^{\circ} \mathrm{C}$ which we would consider invalid because of their cotectic nature, an observation that is supported by the existence of plagioclase feldspar (An78.2-85.2) in whole-rock samples. Furthermore, 27 out of 38 whole-rock samples for suite BII yield PRIMELT3 solutions with $\mathrm{T}_{\mathrm{P}}=1491 \pm 21^{\circ} \mathrm{C}$ but a range of $1463-1559^{\circ} \mathrm{C}$.

Inspection of Fig. 10 shows that Blafjall whole-rocks are related to glasses of the same series by accumulation of the observed range of olivine compositions which is Fo80-85. For suite BII (Schiellerup, 1995), addition of 7\% non-equilibrium olivine (Fo82-86; Fig. 10) to a cotectic glass with $\sim 7.7 \mathrm{wt} \% \mathrm{MgO}$ reproduces the $\mathrm{MgO}$ and $\mathrm{FeO}$ contents of the most magnesian whole rock sample in the series (Fig. 10). Applying PRIMELT3 to this whole-rock composition (\#30.6.7; Schillerup, 1995) yields $\mathrm{T}_{\mathrm{P}}=1558^{\circ} \mathrm{C}$, but this is meaningless because it based on the incorrect assumption that the whole-rock sample is a liquid composition containing equilibrium olivine when in fact the rock is made of a cotectic glass plus accumulative olivine.

In the following sections, we briefly re-evaluate $T_{P}$ data for the NAIP in the light of the above discussions and attempt to identify any key samples that might produce unequivocal values for $T_{P}$. Nevertheless, as we propose below, data from other sources suggest that melting at $\mathrm{T}_{\mathrm{P}} \leq 1450^{\circ} \mathrm{C}$ is plausible for the Blafjall lavas.

\subsubsection{West Greenland}

The majority of picrites from the Vaigat Formation of Baffin and Disko islands contain as much 
as $30 \%$ accumulative olivine (Starkey et al., 2009; 2012) and there is clear disequilibrium between olivine and whole-rock compositions (Fig. 6). To avoid consequences of olivine accumulation we have carefully selected aphyric or sparsely phyric lavas and applied PRIMELT3 to these compositions.

Pedersen et al. (2017) provide a detailed account of the stratigraphy and geochemistry of the Vaigat Formation of Disko Island and surrounding areas and in the lower-most Anaanaa Member describe microphyric to aphyric lavas (their Unit 405) with a total thickness of $\sim 40 \mathrm{~m}$. The last lavas to be erupted in Unit 405 were picrites with accumulative olivine. The very sparsely phyric lavas of Unit 405 cannot have accumulated olivine, and thus one of the complicating issues in obtaining temperature estimates is eliminated. Unit 405 aphyric lavas have $\mathrm{MgO}$ in the range 5.3 to $10.7 \mathrm{wt} \%$ the highest of which is greater than that of any of the pillow glass samples from Baffin or Disko islands previously identified as cotectic liquids. Aphyric lavas with $\mathrm{MgO} / \mathrm{Al}_{2} \mathrm{O}_{3}>0.55$ and $\mathrm{Mg} \#$ 62-66 are likely to have formed from a parental magma with olivine as the sole crystallizing phase (Appendix 3). Twelve Unit 405 lavas with $\mathrm{MgO} \geq 9.0 \mathrm{wt} \% \mathrm{MgO}$ yield PRIMELT3 primary magma solutions which yield $\mathrm{T}_{\mathrm{P}}=1492 \pm 17^{\circ} \mathrm{C}$ (Appendix 3). This is a slightly lower temperature than that of Baffin Island olivine-poor sample DUR1 $\left(\mathrm{T}_{\mathrm{P}} \sim 1530^{\circ} \mathrm{C}\right)$, which Starkey et al. (2012) considered to be a likely non-accumulative composition. No lavas from Unit 408 yield primary magma solutions because they have insufficient $\mathrm{CaO}$ for a given $\mathrm{MgO}$ content to have been derived from melting of peridotite. Pedersen et al (2017 that the higher $\mathrm{SiO}_{2}$, and lower $\mathrm{CaO}$ for a given $\mathrm{MgO}$ content in Unit 408 lavas than in Unit 405 aphyric lavas is a consequence of crustal contamination shale lithologies (Pedersen et al., 2017. Picrites from the top of Unit 405 contain $23 \mathrm{wt} \% \mathrm{MgO}$ and have presumably experienced olivine accumulation. The picrites do not yield PRIMELT3 solutions because they are identified as having fractionated augite which means they are too deficient in $\mathrm{CaO}$ at a given $\mathrm{MgO}$ to have been derived from mantle peridotite.

Fig. 11 summarizes compositions of Vaigat Formation picrites and those of the stratigraphically overlying Maligat-Formation basalts, all filtered for the effects of crustal contamination. The filter used is $\varepsilon \mathrm{Nd}_{60}>+5 \mathrm{Nd}$-isotopic because the Precambrian metamorphic basement of Greenland and the BPIP contains unradiogenic $\mathrm{Nd}\left(\varepsilon \mathrm{Nd}_{60}<-20\right.$; Larsen and Pedersen 2009a) whereas most mantle derived magmas magmas have $\varepsilon \mathrm{Nd}_{60}>+5$ (Thompson et al., 1982; Larsen and Pedersen, 2009a; Hole et al., 2015a). Unit 405 aphyric basalts fall close to the plagioclase-in composition of a liquid line of descent (LLD) for a PRIMELT3 model primary magma to these samples (Fig. 11). The few Maligat Formation lavas for which there are isotopic data fall along the same LLD but for multiphase crystallization of $\mathrm{Ol}+\mathrm{Pl}+\mathrm{Cpx}$. There are 
no isotopically uncontaminated lavas from the Vaigat or Maligat formations that have $\mathrm{SiO}_{2} / \mathrm{FeO}>5.5$. Because $\mathrm{SiO}_{2} / \mathrm{FeO}$ increases with decreasing pressure of melting (Fig. 4) this implies that all Vaigat and Maligat formation lavas are related to a LLD for a primary magma formed at $\mathrm{P} i>3.5$ (Fig. 11). The lower $\mathrm{SiO}_{2} / \mathrm{FeO}$ of the highest $\mathrm{Mg \#}$ Vaigat Formation lavas is readily explained by the accumulation of olivine in a melt similar in composition to Unit 405 aphyric lavas. Fig. 11 also shows results calculated for the addition of olivine Fo 88 to a range of MORB glasses along the $\mathrm{L}+\mathrm{Ol}+\mathrm{Pl}$ cotectic to form a picrite with $\mathrm{Mg} \#$ approaching that of the most Mg-rich glass from the Vaigat Formation. Variable amounts of olivine accumulation in a MORB glass would produce a range of compositions that occupy the shaded region in Fig. 11, all of which would have higher $\mathrm{SiO}_{2} / \mathrm{FeO}$ than any of the Vaigat Formation lavas. To generate the observed $\mathrm{FeO}$ contents and $\mathrm{SiO}_{2} / \mathrm{FeO}$ would require olivine accumulation in a cotectic liquid with $\leq 8 \mathrm{wt} \% \mathrm{MgO}$ and none of the resultant compositions would have enough $\mathrm{CaO}$ to yield PRIMELT3 solutions. Therefore, it seems very unlikely that any of the Vaigat Formation lavas were generated as were primitive MORB at ambient $\mathrm{T}_{\mathrm{P}}$ by olivine accumulation. Nevertheless, detailed consideration of the accumulative picrites of the Vaigat Formation and their component olivine (Appendix 3) shows that accumulation of theprevalent olivine compositions of Fo86-90 do not substantially alter the overall temperature profile that can be derived for the lavas using PRIMELT3.

\subsubsection{Iceland}

Most Icelandic glass analyses (Thompson and Maclennan, 2011) are identified as cotectic compositions (Appendix 1). Glasses with $\mathrm{MgO}$ in the range 8.8-10.0 wt\% from Kistufel, Herdubriedatogl and Borgarhraun do not all appear to be cotectic compositions and these yield PRIMELT3 $\mathrm{T}_{\mathrm{P}}$ which are summarized in Table 1. For all three locations $\mathrm{T}_{\mathrm{Ol}}$ for the model primary magma at $0 \mathrm{GPa}$ is shown, as is $\mathrm{T}_{\mathrm{Ol}}$ calculated for the erupted glass after correction for fractional crystallization of olivine of the amount required by PRIMELT3. For Kistufel, Tol based on olivine-glass pairs (Fig. 6) agrees well with that calculated from PRIMELT3 whereas $\mathrm{T}_{\mathrm{Ol}-\mathrm{Sp}}$ is higher by $\sim 22^{\circ} \mathrm{C}$. Similar calculations for Herdubreidatogl provide excellent agreement between all three methods, although the higher temperature population found in the glassolivine pairs is not evident in the other methods. For Borgarhraun, there is no evidence from the glass samples for $\mathrm{T}_{\mathrm{Ol}-\mathrm{Sp}}$ as high as $1382^{\circ} \mathrm{C}$. Hole and Millett (2016) obtained higher $\mathrm{T}_{\mathrm{P}}$ estimates of $\sim 1475-1500^{\circ} \mathrm{C}$ for whole-rocks from Icelandic rift zones and $1450^{\circ} \mathrm{C}$ for rift- flank lavas, but these were generated assuming extremely reducing conditions $\left(\mathrm{Fe}^{3+} / \mathrm{Fe}_{\mathrm{T}} \sim 0.05\right)$, which, according to Shorttle et al. (2015), are unlikely at Iceland. For a more realistic oxidation state of 
$\mathrm{Fe}^{3+} / \mathrm{Fe}_{\mathrm{T}} \sim 0.09$ (Shorttle et al., 2015; Gaetini, 2016) these $\mathrm{T}_{\mathrm{P}}$ estimates decrease by $\sim 50^{\circ} \mathrm{C}$ giving a maximum of $1450^{\circ} \mathrm{C}$. We conclude that the maximum $\mathrm{T}_{\mathrm{P}}$ that can be derived for modern Icelandic lavas is $\sim 1450^{\circ} \mathrm{C}$.

Reykjanes Peninsula picrites (Elliott et al., 1991; Skovgaard et al., 2006; Kokfelt et al., 2006; Brandon et al., 2007) are probably the best examples of high $\mathrm{MgO}$ lavas that represent the effects of accumulation of olivine in a cotectic glass (Fig. 11; see also section 2.3 above). To generate the $\mathrm{SiO}_{2} / \mathrm{FeO}$ up to 6.3 in these lavas requires melting a low pressures and low $\mathrm{T}_{\mathrm{P}}$, but the data fall close to the vectors for accumulation of olivine of moderate Fo content $(\sim 88)$ often found in primitive basalt. Consequently, these lavas, which incidentally, do not yield PRIMELT3 primary magma solutions, do not require high temperatures to generate their high $\mathrm{MgO}$ contents.

\subsubsection{East Greenland, BPIP and FIBG.}

Few samples from East Greenland yield any temperature information. This is largely because lavas with $>9$ wt $\% \mathrm{MgO}$ are scarce. In East Greenland and Faroe Islands most lavas have $\mathrm{Mg} \#<60$ and crystallized augite during their petrogenesis. However, some low- $\mathrm{TiO}_{2}$ sparsely olivine-phyric from the Milne Land Formation (Waight and Baker, 2012) contain 10- 16 wt\% $\mathrm{MgO}$, the higher $\mathrm{MgO}$ samples probably containing accumulative olivine. PRIMELT3 solutions for these lavas yield $1518 \pm 10^{\circ} \mathrm{C}$. However, of note are three samples from the seawarddipping-reflector sequences of SE Greenland which suggest that, using PriMelt 3, $\mathrm{T}_{\mathrm{P}}$ was no greater than $\sim 1440^{\circ} \mathrm{C}$.

For the BPIP we have scrutinized the data used by Hole and Millett (2016), removing samples that fail the test for cotectic compositions presented herein (Appendix 2). In addition, we have also used more oxidizing conditions $\left(\mathrm{Fe}_{2} \mathrm{O}_{3} / \mathrm{TiO}_{2}=1.0\right.$; Herzberg and Asimow, 2015; Hole, 2018) during melting than previously published estimates of $1500^{\circ} \mathrm{C}$ and now suggest $1480 \pm 30^{\circ} \mathrm{C}$ as a reasonable $\mathrm{T}_{\mathrm{P}}$ estimate. The same exercise carried out on FIBG low- $\mathrm{TiO}_{2}$ lavas gives $1506 \pm 25^{\circ} \mathrm{C}$. The only glass data from these areas are for pillow lavas from commercial well $217 / 15-1 \mathrm{Z}$ and these are now identified as cotectic compositions typical of the high- $\mathrm{TiO}_{2}$ lava series (Soager and Holm, 2011; Millett et al., 2017) and they do not yield any temperature information.

In conclusion, scrutiny of available temperature data for the NAIP leads us to conclude that many existing $\mathrm{T}_{\mathrm{P}}$ estimates are probably too high. The maximum temperature we obtain here is $\mathrm{T}_{\mathrm{P}} \sim 1500^{\circ} \mathrm{C}$ for Baffin Island and Disko Island. Temperatures up to $1520^{\circ} \mathrm{C}$ obtained for low $\mathrm{TiO}_{2}$ lavas from East Greenland using PRIMELT3 cannot be verified by other means due to a 
lack of additional data. For Iceland, glasses lying along the olivine liquidus provide the best estimate of a maximum of $\mathrm{T}_{\mathrm{P}}=1450^{\circ} \mathrm{C}$ which can be verified using both olivine-melt and olivine-spinel equilibria. The above discussion has necessarily centred on melting of dry peridotite and we now consider the effects that volatiles might have melt production.

\section{The role of volatile-bearing peridotite in the genesis of NAIP magmas}

Nichols et al. (2002) found 620-920 ppm $\mathrm{H}_{2} \mathrm{O}$ at $8 \mathrm{wt} \% \mathrm{MgO}$ in un-degassed pillow glasses from Iceland, and Jamtveit et al. (2001) recorded up to 3-7 ppm $\mathrm{H}_{2} \mathrm{O}$ in olivine from Icelandic lavas. These data suggest derivation from a mantle source with $>300 \mathrm{ppm} \mathrm{H}_{2} \mathrm{O}$. This implies that the source of Icelandic basalts was also wet. Olivine in lavas from East Greenland (Kangerlussuaq picrites) have even higher water contents (up to $18 \mathrm{ppm}_{2} \mathrm{O}$ ) whereas, olivine in West Greenland picrites and FIBG low- $\mathrm{TiO}_{2}$ lavas have negligible $\mathrm{H}_{2} \mathrm{O}$ contents (Jamtveit et al., 2001). High concentrations of $\mathrm{H}_{2} \mathrm{O}$ in picrites were also reported by Metreich et al. (2014) for the Azores Islands, and they argued that magma generation there involved decompression melting of a water-enriched mantle domain containing 680-570 ppm $\mathrm{H}_{2} \mathrm{O}$ with an estimated temperature excess of $\leq 120^{\circ} \mathrm{C}$ with respect to the Mid-Atlantic Ridge giving $\mathrm{T}_{\mathrm{P}} \sim 1470^{\circ} \mathrm{C}$.

If we assume that addition of $\mathrm{H}_{2} \mathrm{O}$ to peridotite causes the same rate of temperature suppression regardless of the solidus parameters used (Sarafian et al., 2017; Dasgupta et al.,2007), then for $450 \mathrm{ppm} \mathrm{H}_{2} \mathrm{O}$ added to the solidus of Herzberg and Asimow (2015), melting commencing at $2.8 \mathrm{GPa}$ would require $\mathrm{T}_{\mathrm{P}} \sim 1395^{\circ} \mathrm{C}$. The composition of the melt formed by addition of the relatively small quantities of $\mathrm{H}_{2} \mathrm{O}$ is unlikely to be much different from that of dry melting. Returning briefly to the $\mathrm{T}_{\mathrm{P}}$ estimates for Icelandic glasses, maintaining $\mathrm{P} i$, $\mathrm{P} f$ and therefore melt fraction for dry melting at $\mathrm{T}_{\mathrm{P}} \sim 1450^{\circ} \mathrm{C}$, we find that $\mathrm{T}_{\mathrm{P}}$ would decrease to $\sim 1400^{\circ} \mathrm{C}$ for peridotite $+200 \mathrm{ppm} \mathrm{H}_{2} \mathrm{O}$ and $\sim 1350^{\circ} \mathrm{C}$ for peridotite $+450 \mathrm{ppm} \mathrm{H}_{2} \mathrm{O}$. However, such a temperature decrease would be evident in $\mathrm{T}_{\mathrm{Ol}}$ and $\mathrm{T}_{\mathrm{Ol}-\mathrm{Sp}}$ data, which is not the case. $\mathrm{T}_{\mathrm{P}}$ estimates for East Greenland low $-\mathrm{TiO}_{2}$ lavas would decrease by $\sim 90^{\circ} \mathrm{C}$ to $\sim 1400^{\circ} \mathrm{C}$ in the presence of $450 \mathrm{ppm} \mathrm{H}_{2} \mathrm{O}$.

Dasgupta et al. $(2007 ; 2013)$ investigated the melting behaviour of peridotite for the addition of 5-20 wt $\% \mathrm{CO}_{2}$ (Fig. 11) and developed an algorithm that can be applied to $\mathrm{CO}_{2}$-present melting along any dry solidus. At $3 \mathrm{GPa}$, increasing $\mathrm{CO}_{2}$ systematically suppresses the solidus by $\sim 45^{\circ} \mathrm{C}$ for $5 \mathrm{wt} \% \mathrm{CO}_{2}$ to $\sim 155^{\circ} \mathrm{C}$ at $20 \mathrm{wt} \% \mathrm{CO}_{2}$. As applied to the Hirschmann (2000) dry solidus (Fig. 11) and for $\mathrm{P} i=2.8 \mathrm{GPa}$, the Dasgupta et al. (2013) model requires $\mathrm{T}_{\mathrm{P}} \sim 1420^{\circ} \mathrm{C}$ for dry peridotite and $\mathrm{T}_{\mathrm{P}} \sim 1340^{\circ} \mathrm{C}$ for peridotite $+10 \mathrm{wt} \% \mathrm{CO}_{2}$ to generate melt. The composition of the first-formed melts also changes systematically with increasing $\mathrm{CO}_{2}$, compositions being 
driven to lower $\mathrm{SiO}_{2}$ and higher $\mathrm{CaO}$. Such is the magnitude of these changes that tholeiites like those that dominate LIPs are not produced even for relatively conservative mount of $\mathrm{CO}_{2}$ addition (Herzberg and Asimow, . Instead, strongly Si-undersaturated compositions predominate (e.g. basanite and derivative tephrite). Whereas such compositions are uncommon in LIPS it is interesting to note that some of the Eocene (53-54 Ma) lavas of the Prinsen af Wales Bjerg in East Greenland (Hansen et al., 2002; Peate et al., 2003) have compositions that might be consistent with melting in the presence of $\mathrm{CO}_{2}$. Nevertheless, the data of Dasgupta et al. (2007; 2013) suggest that these lavas do not require substantially elevated $T_{P}$ for their generation.

\section{Melting lithologically heterogeneous mantle}

Herzberg et al. (2016), Lambart (2017) and Hole (2018) all showed that the Ni, Ca, Mn and Fe contents of component olivines in NAIP lavas are consistent with a peridotite-dominated source. This contrasts with data for olivine in lavas from other LIPs that carry evidence of melt derived from pyroxenite-rich sources (e.g. Hawaii, Sobolev et al., 2006; Herzberg, 2006; Herzberg, 2011; Frey et al., 2016; Siberian Traps; Sobolev et al., 2007; 2009; Karoo, Heinonen et al., 2014; Hole et al., 2015b; Carribean-Columbian LIP; Gazel et al., 2011). Nevertheless, petrogenetic models for Iceland rift zone magmas require a contribution from pyroxenite to generate the observed crustal thicknesses in northern Iceland (Shorttle et al., 2014; Lambart, 2017). Furthermore, as noted by Lambart (2017) and Hole (2018), melt generated from some pyroxenite and some hybrid pyroxenite-peridotite sources will be basaltic, and consequently, the lack of a clear signature of pyroxenite melting in NAIP lavas does not preclude its involvement in magmatism. Here, we consider the processes that transform recycled crust into pyroxenite, examine it melting behaviour and finally consider the role of pyroxenite in magmatism.

\subsection{Generation of pyroxenite from recycled ocean crust.}

On subduction, the transformation of basaltic oceanic crust produces quartz or coesite eclogite in the upper mantle and these are termed Stage-1 pyroxenites (Herzberg, 2011). Cumulates of troctolite and olivine gabbro will yield olivine-pyroxenite lithologies $(\mathrm{Ol}+\mathrm{Cpx}+\mathrm{Gt})$ in the upper mantle. Stage-1 pyroxenites therefore comprise two distinct lithologies; silica enriched (SE) - relating to metamorphism and recycling of basaltic crust; and silica deficient (SD) - relating to recycling of gabbro and other cumulates (Herzberg, 2011). Experimental phase equilibra of pyroxenites show that at high pressure (> 1.7 GPa) (Kogiso 
et al., 2003; Lambart et al., 2012; 2013), there is a thermal divide defined by the Enstatite (En)Diopside (Di)-Alumina plane which includes garnets and aluminous pyroxene components CaTschermak (CaTs) and $\mathrm{Mg}$-Tschermak (MgTs) in the $\mathrm{CaO}-\mathrm{MgO}-\mathrm{Al}_{2} \mathrm{O}_{3}-\mathrm{SiO}_{2}$ tetrahedron (Fig. 12; O'Hara, 1972). This divide separates SE pyroxenites which lie on the silica-rich side of the En-CaTs join from SD pyroxenites which lie to the silica-poor, i.e., olivine-rich, side of the EnCaTs join (Fig. 12a).

During recycling of subducted crust in the upper mantle, convective mixing and stirring will fold, stretch, and thin subducted crust (Graham et al., 2006; Herzberg, 2011). When this happens, solid-state reactions will occur because the silica-bearing recycled crust lithology is not stable in an olivine-rich peridotite host. Reactions involving olivine + free silica $=$ orthopyroxene, between the recycled crust and host peridotite, will produce a Stage-2 pyroxenite. However, most high-MgO crustal cumulates will become olivine pyroxenites in the upper mantle $(\mathrm{Ol}+\mathrm{Cpx}+\mathrm{Gt})$. In general, olivine pyroxenite lithologies are expected to be abundant in recycled crust that has been stirred, stretched and thinned, and they have the potential to yield low- $\mathrm{SiO}_{2}$ silica-undersaturated alkalic magmas (Keshav et al., 2004; Kogiso et al., 2003, 2004; Herzberg, 2011). If all the free silica reacts out, the mantle would consist of peridotite and layers of silica-free pyroxenite or olivine pyroxenite giving a 'marble cake' mantle (Allegre and Turcotte, 1986). Substantial mixing may occur between peridotite and pyroxenite layers, olivine pyroxenite might grade into re-fertilized peridotite, and complete mixing might destroy all remnants of the original recycled crust (Herzberg, 2011).

\subsection{Melting mixed peridotite-pyroxenite lithologies}

Generation of melt from decompression of mixed pyroxenite and peridotite sources might involve a variety of melt-rock, melt-melt, and rock-rock reactions (e.g. Hirschmann et al., 2003; Herzberg, 2011; Frey et al., 2016). A range of pyroxenite and eclogite solidi are shown in Fig. 13 and compared to that of dry peridotite. G2 is a quartz eclogite formed from metamorphism of basaltic oceanic crust (Pertermann and Hirschmann, 2003) and it exhibits the steepest solidus P-T profile (Fig. 13) of materials used in melting experiments. The Melt-PX model of Lambart et al. (2016) predicts that G2 alone would begin to melt at $\sim 7.7 \mathrm{GPa}(>280$ $\mathrm{km}$ ) for $\mathrm{T}_{\mathrm{P}}=1450^{\circ} \mathrm{C}$ and would undergo $\sim 40 \%$ melting after ascent to $0.5 \mathrm{GPa}$.. At the same $\mathrm{T}_{\mathrm{P}}$, peridotite would begin to melt at $\sim 2.8 \mathrm{GPa}$. Most SE pyroxenites, such as G2, do not generate basaltic but dacitic melt compositions (Pertermann and Hirschamnn, 2003) which are too $\mathrm{SiO}_{2}$ rich and $\mathrm{CaO}$ - and $\mathrm{MgO}$-poor to be parental to basalts (Fig. 12b). However, interaction between dacitic melt and melt derived from peridotite might generate silica-saturated or oversaturated 
magmas (quartz in the CIPW norm) with higher $\mathrm{SiO}_{2}$ and lower $\mathrm{CaO}$ at a given $\mathrm{MgO}$, than magmas derived from peridotite alone. Such melts might resemble lavas from Hawaiian shield volcanoes which are thought to be derived from an SE pyroxenite-rich source (Sobolev et al., 2005; Herzberg, 2006). Alternatively, by the time peridotite begins to melt, pyroxenite G2 might melt to $\sim 100 \%$ and at this stage, melt of pyroxenite reacts with peridotite to form a hybrid enriched peridotite lithology. Indeed, Rosenthal et al. (2018) note that in upwelling heterogenous mantle domains, siliceous eclogitic melts will react with encapsulating mantle peridotite, effectively refertilising it and producing hybrid pyroxene- and garnet-rich rocks. Subsequent melting of such sources materials may lead to compositionally diverse primitive magmas including low $\mathrm{Ca} / \mathrm{Al}$ and high $\mathrm{Na} / \mathrm{Ca}$ magmas depending on the precise composition of the recycled eclogite.

Frey et al. (2016) showed that the composition of melt formed by either of these melt-melt or solid-solid reactions would have major element compositions appropriate for magmas parental to Hawaiian shield-building tholeiites (e.g. Koolau, Mauna Loa). However, such melt compositions but are quite unlike typical Iceland rift zone lavas or olivine tholeiites from Disko or Baffin Islands (Hole and Millett, 2016; Hole, 2018). G2 is thus not an appropriate pyroxenite composition to occur in large volume beneath Iceland.SD pyroxenite 77SL-582 (Keshav et al., 2004; from Salt Lake Crater, Oahu, Hawaii; Fig. 13) has a solidus P-T profile that is very much closer to that of mantle peridotite than $\mathrm{G} 2$. At $\mathrm{T}_{\mathrm{P}}=1450^{\circ} \mathrm{C}, 77 \mathrm{SL}-582$ would start to melt at $\sim 3.6$ GPa and could produce $\sim 30 \mathrm{~km}$ of new crust by $0.5 \mathrm{GPa}$. 77SL-582 produces basaltic melts at 2.0-2.5 GPa and $1360-1440^{\circ} \mathrm{C}$ (Keshav et al., 2004) and except for very extensive melting ( $\mathrm{F}>70 \%$ ) initial liquids are silica under-saturated (equivalent to alkali olivine basalt) becoming less silica undersaturated with increasing extent of melting (Fig. 12b). For decompression melting of a mixed lithology comprising SD pyroxenite 77SL-582 and peridotite, the melt products from both components would be basaltic. Consequently, melt-melt, solid-solid or solid-melt interactions involving SD pyroxenite and peridotite would all produce basaltic magma. We concur with Lambart (2017), who argued that there is no need to involve the direct contribution of melts derived from a recycled basalt component (e.g., G2) to explain the compositional variability of the Icelandic basalts in rift zones. Instead,the range of observed melt compositions can be generated by melting of olivine-bearing hybrid lithologies (e.g., KG1; Lambart, 2017) formed by melt-solid or solid-state reactions between silica-deficient (SD) pyroxenite $(10 \%)$ and peridotite $(90 \%)$; this model can also explain the observed thickness of crust at Iceland's rift zones (Matthews et al., 2016; Lambart, 2017), as discussed below. 


\subsection{Source of NAIP pyroxenite.}

Frey et al. (2016) suggested that the pyroxenite component at Hawaii begins melting at $\sim 150 \mathrm{~km}(\sim 4.7 \mathrm{GPa})$ and Herzberg (2011) showed that the parental magma to lavas from Koolau were related to a 3-4 GPa cotectic in the system $\mathrm{Ol}-\mathrm{CaTs}-\mathrm{Qz}$. For the hybrid pyroxeniteperidotite lithological model for Icelandic magmatism proposed by Lambart (2017), melting begins at 3-4 GPa, the pressure variation depending on the bulk composition of the hybrid source. Significantly, none of these threshold pressures of melting necessarily require recycling of subducted crust to any greater depth than $\sim 5 \mathrm{GPa}$.

Foulger et al. (2005) proposed that subducted Iapetus crust may have been trapped in the Laurasian continental mantle lithosphere during continental collision in the Caledonian orogeny at $\sim 420-410 \mathrm{Ma}$ and recycled locally back into the asthenosphere beneath the mid- Atlantic ridge by lithospheric delamination when the north Atlantic opened. Whereas their model required melting of eclogite, we refine this to the specific lithology of SD pyroxenite formed from prograde metamorphism of gabbroic cumulates within the oceanic crust. Consequently, we argue that the hybrid petrological source beneath the NAIP was generated as a predictable consequence of reactions between Iapetus crust and upper mantle peridotite and does not require recycling to the Core-Mantle Boundary. In addition, as will be discussed in section 8 , the very high ${ }^{3} \mathrm{He} /{ }^{4} \mathrm{He}$ ratios observed in some Icelandic basalts may derive from helium preserved in U+Th-poor residual Caledonian or even older oceanic mantle lithosphere or olivine-rich cumulates in the crustal section (Foulger et al., 2005).

\section{Isotopic considerations and $\Delta \mathrm{Nb}$.}

Deep recycling of lithosphere over periods of gigayears, coupled with multiple meltextraction events generates isotopic heterogeneity in the mantle. Additionally, rare gas isotopes, and specifically ${ }^{3} \mathrm{He}$, may reflect contributions to magmatism from primordial, un- degassed lower mantle sources or even from Earth's core (e.g. Stuart et al., 2003; Dale et al., 2009; Peate et al., 2010; Moreira, 2013; Day, 2016; Péron et al., 2018). However, a problem facing all isotopic studies in continental flood basalt provinces is separating the effects of crustal contamination from those of mantle heterogeneity (e.g. Hole et al., 2015a; Day, 2016). Prebreak-up lavas of the NAIP erupted through thick continental crust of Archaean/Proterozoic and many, but not all, carry isotopic fingerprints of crustal contamination as will be described briefly below. However, the possible absence of sialic continental crust beneath much of Iceland (but see below and Torsvik et al., 2017) means that Icelandic basalts have been the main probes used to examine the presumed uncertainties of isotopic variability of mantle sources in 
the NAIP.

\subsection{Crustal contamination}

Near-primary mafic melts of the NAIP had low abundances of incompatible trace elements, and particularly the rare earth elements (REE) and $\mathrm{Pb}$, because they represent large melt fractions. Sialic crustal rocks in the region have high abundances of the same elements. This means that even small amounts of crustal contamination can cause significant changes in isotopic compositions from mantle values. For example, lavas from Skye exhibit ${ }^{206} \mathrm{~Pb} / 204 \mathrm{~Pb}$ $=14.3-17.8, \varepsilon \mathrm{Nd}_{60}=-27.9$ to +8.8 and ${ }^{87} \mathrm{Sr} /{ }^{86} \mathrm{Sr}_{60}=0.7030-0.7052$ consistent with the interaction of upper mantle-derived melts with $\sim 10 \%$ Lewisian granulite or amphibolite crust (Thompson et al., 1982; 1986; Dickin et al., 1987; Font et al, 2008; Hole et al., 2015a). Picritic lavas from Disko Island and East Greenland exhibit similarly large variations in $\mathrm{Nd}-$ and $\mathrm{Pb}$ isotopic compositions (Larsen and Pedersen, 2009; Pedersen et al., 2017). However, some Baffin Island picrites have $\mathrm{Pb}-, \mathrm{Sr}$ - and $\mathrm{Nd}$-isotopic compositions within the range for modern Icelandic basalts and as such may have escaped significant crustal contamination (Stuart et al., 2003; Dale et al., 2009; Starkey et al., 2009). However, since contamination of NAIP lavas erupted onto the continental crust is pervasive, we provide a summary of the significance of isotopic arrays at Iceland, where crustal contamination should be minimal. However, Torsvik et al. (2017) have also argued that some Icelandic basalts may contain a contribution from continental crust. This will be discussed below in the context isotopic arrays for Icelandic basalts.

\subsection{Isotopic arrays - Iceland}

Within volcanically active Icelandic rift zones, isotopic systems may show coherent relationships with one another, but on length scales of $>140 \mathrm{~km} \mathrm{~Pb}$-isotope systematics appear to be de- coupled from $\mathrm{Sr}$ and Nd isotopes (Shorttle et al., 2013). Kempton et al. (2000) identified at least four different mantle components all of which are different from worldwide MORB. Thirlwall et al. (2004) proposed that five hypothetical isotopic end-members could be identified in the data for Icelandic basalts and for MORB erupted along the Reykjanes Ridge. Two 'enriched' components, one depleted component and a further component like the EMI source (Hart, 1988) existed simultaneously beneath Iceland.

A summary of the possible origins of each component based on Thirlwall et al., (2004) are;

i. MORB source asthenosphere ('depleted')

ii. Hydrothermally altered basaltic crust formed in the past $15 \mathrm{Ma}$ ('enriched' source)

iii. Enriched mantle EMI which is also found elsewhere in the ocean basins ('enriched') 
iv. Recycled ancient oceanic crust ('depleted')

v. Recycled young oceanic crust ('enriched')

As discussed earlier (Section 5) although major element compositions of Icelandic basalts may require the interaction between at least two lithologies i.e. peridotite and pyroxenite, isotope systematics clearly demand more variability than just two sources, but we concur with Shorttle et al. (2013) that it is difficult to see direct evidence for the lithological character of these in any geochemical data.

Torsvik et al. (2015) proposed some lavas from Oraefajokull (eastern rift flank of Iceland) have similar isotopic signatures to the EMII component of Hart (1988) that are found elsewhere in the ocean basins and which is generally held to have its origins in continental crust recycled through mantle plumes. The trend for ${ }^{87} \mathrm{Sr} /{ }^{86} \mathrm{Sr}$ versus ${ }^{206} \mathrm{~Pb} /{ }^{204} \mathrm{~Pb}$, for example, exhibits this trend. Oraefajokull lavas exhibit some of the most radiogenic $\mathrm{Sr}$-and unradiogenic $\mathrm{Nd}$-isotopic compositions $\left({ }^{87} \mathrm{Sr} /{ }^{86} \mathrm{Sr}=0.7035-0.7038\right.$ and ${ }^{143} \mathrm{Nd} /{ }^{144} \mathrm{Nd}=0.51296-0.51300$ respectively) for any Iceland lavas, but they do not fall on the well-defined $\mathrm{Pb}$-isotopic trends formed by lavas from Icelandic rift-zone lavas. Consequently, rather than appealing to mantle heterogeneity as a reason for these isotopic characteristics, Torsvik et al. (2017) argued that a sliver of continent was broken off from Greenland during the Early Eocene and is now located beneath southeast Iceland where it locally contaminates magmas.

\subsection{Helium isotopes}

Of the two stable isotopes of helium, non-cosmogenic ${ }^{3} \mathrm{He}$ is primordial and was incorporated in the Earth as it accreted, whereas ${ }^{4} \mathrm{He}$ is produced by radioactive decay of $\mathrm{U}$ and Th isotopes. Mid-ocean- ridge basalts generally have $\mathrm{R} / \mathrm{R}_{\mathrm{A}}\left({ }^{3} \mathrm{He} /{ }^{4} \mathrm{He}\right.$ normalized to the atmospheric ratio) values of $8 \pm 1$ (see review of Moreira, 2013) whereas Ocean Island Basalts (OIB), purportedly associated with deep mantle plumes, exhibit a large range in $R / R_{A}(5-42)$. Baffin Island picrites contain inclusions in olivine which have the most extreme helium isotopic signatures of any terrestrial samples (R/R $\mathrm{R}_{\mathrm{A}} \sim 50$; Stuart et al., 2000; 2003; Starkey et al., 2009) whereas glasses and mafic phenocrysts in lavas from Iceland have $\mathrm{R} / \mathrm{R}_{\mathrm{A}} 5-35$ with a single analysis at $\mathrm{R} / \mathrm{R}_{\mathrm{A}}=47.5$ (Harðardóttir et al., 2018). High ${ }^{3} \mathrm{He} /{ }^{4} \mathrm{He}$ mantle sources must have had a low time-integrated $(\mathrm{U}+\mathrm{Th}) /{ }^{3} \mathrm{He}$ to prevent accumulation of radiogenic ${ }^{4} \mathrm{He}$ by in situ decay of Th and U. Two classes of models have been suggested to explain the origin of the high ${ }^{3} \mathrm{He} /{ }^{4} \mathrm{He}$ reservoir in the mantle; one requires and origin from undegassed primordial sources and the other derivation from melt residues dating from early in Earth history.

The first case requires a helium contribution from primitive, unfractionated, undegassed 
sources deep in the mantle or in the core (Bouhifd et al., 2013; Dygert et al., 2018) that retain near-primordial high ${ }^{3} \mathrm{He} /{ }^{4} \mathrm{He}$. This primitive mantle must be separated from degassed uppermantle by a boundary layer at $670 \mathrm{~km}$ or at the core-mantle boundary, such that hypothetical hot mantle plumes entrain ${ }^{3} \mathrm{He}$ from the undegassed source. Ellam and Stuart (2004) showed that the high ${ }^{3} \mathrm{He} /{ }^{4} \mathrm{He}$ Baffin Island lavas require only a small proportion $(<10 \%)$ of primordial mantle in their sources, and that most OIB demand $<2 \%$. Recent variants on a canonical two-layer model include the Basal Magma Ocean (BMO) model of Labrosse et al. (2007) which requires entrainment of high ${ }^{3} \mathrm{He} /{ }^{4} \mathrm{He}$ crystals generated in a primordial magma ocean. However, since high ${ }^{3} \mathrm{He} /{ }^{4} \mathrm{He}$ is not a universal feature of all purported mantle plumes (e.g. Jackson et al., 2017; Garapic et al., 2015; Graham et al., 2014) it has been argued that only some plumes sample primordial mantle, and these are the hottest plumes (Iceland and Hawaii; Jackson et al., 2017), with the greatest hotspot buoyancy flux, and which exhibit seismic low-velocity anomalies at depths of 200 kilometres (Garapic et al., 2015; Jackson et al., 2017). This also means that there should be a relationship between 'plume temperature' and ${ }^{3} \mathrm{He} /{ }^{4} \mathrm{He}$. Since we have shown in detail that $T_{P}$ determinations for any LIP are open to interpretation, the temperature- ${ }^{3} \mathrm{He} /{ }^{4} \mathrm{He}$ correlation cannot be readily tested.

In the second case, ancient melt residues in subducted oceanic lithosphere may have high ${ }^{3} \mathrm{He} /{ }^{4} \mathrm{He}$ because partial melting at ocean ridges extracts almost all the $\mathrm{U}$ and $\mathrm{Th}$ from the mantle source and accumulation of ${ }^{4} \mathrm{He}$ in the melt residue is restricted and the original high ${ }^{3} \mathrm{He} /{ }^{4} \mathrm{He}$ mantained (Anderson, 1998; Meibom et al., 2003). Natland (2003) argued that high ${ }^{3} \mathrm{He} /{ }^{4} \mathrm{He}$ in olivine phenocrysts indicates the age of the original capture of $\mathrm{He}$ in olivines, but not the time when younger magma extracted it from ancient sources (see also Appendix 1, section 3). Natland (2003) showed that $\mathrm{He}$, along with $\mathrm{CO}_{2}$, is captured as a gas in bubbles in boundary layers next to crystallizing olivine and $\mathrm{Cr}$ spinel. The $\mathrm{He}$ and $\mathrm{CO}_{2}$ is not directly associated with entraining silicate melt. Therefore, unlike $\mathrm{Sr}, \mathrm{Nd}, \mathrm{Pb}, \mathrm{Hf}$ and $\mathrm{Os}$ isotopes, helium partitioning into olivine is not related to mineral- melt partition coefficients but to diffusion associated with bubble formation. This provides a method of separating $\mathrm{Th}$ and $\mathrm{U}$ from helium and preventing isotopic changes in helium compositions over time, thus allowing decoupling of He from other isotopic tracers as subsequently observed by other workers (Starkey et al., 2009; Dale et al., 2009; Day, 2016). In the case of Baffin Island and west Greenland, it is therefore possible that primordial helium (with high intact ${ }^{3} \mathrm{He} /{ }^{4} \mathrm{He}$ ) was preserved in olivine time-capsules that were subsequently ruptured and the He captured by ascending melt formed at $\sim 61 \mathrm{Ma}$. This led Foulger et al. (2005) to propose that the high ${ }^{3} \mathrm{He} /{ }^{4} \mathrm{He}$ observed in some Icelandic basalts was derived from old helium preserved in preserved in $\mathrm{U}+\mathrm{Th}$-poor residual Caledonian oceanic 
mantle lithosphere or olivine-rich cumulates in the crustal section.

Dale et al. (2009) noted that the ultimate source of the high ${ }^{3} \mathrm{He} /{ }^{4} \mathrm{He}$ component in Baffin Island lavas was unclear, and in terms of osmium-isotope mass balance, Baffin and Disko island picrites cannot contain any significant contribution from the outer core or from old recycled crustal material, as both would impart a radiogenic ${ }^{187} \mathrm{Os} /{ }^{188} \mathrm{Os}$ signature that is not observed in the lavas. Dale et al. (2009) concluded that the high ${ }^{3} \mathrm{He} /{ }^{4} \mathrm{He}$ signature in NAIP picrites has three possible explanations;

(i) it is present in a typical upper mantle source but is only tapped during episodes of high-degree melting of hot mantle;

(ii) it is derived from a primitive mantle component which has been mixed with recycled oceanic crust and depleted MORB-source mantle;

(iii) Helium is largely decoupled from $\mathrm{Os}$ and $\mathrm{Nd}$ and is dominated by addition of a $\mathrm{He}-$ rich, high ${ }^{3} \mathrm{He} /{ }^{4} \mathrm{He}$ component, probably primordial in nature, without complementary addition of other elements.

Finally, Day (2016) questioned the need for a primordial (ancient non-chondritic) reservoir to provide ${ }^{3} \mathrm{He}$ to continental flood basalts and argued that pervasive crustal contamination and partial melting of heterogeneous mantle sources, generated by plate tectonic processes, can account for their isotopic variability. We conclude that there is more than one explanation for high ${ }^{3} \mathrm{He} /{ }^{4} \mathrm{He}$ in NAIP lavas and that He-isotopes are not necessarily an indicator of the existence of a deep-seated mantle plume.

\subsection{Delta niobium $(\triangle N b)$}

Fitton et al. (1997) argued that lavas from Iceland's active and historically active volcanic zones possess higher $\mathrm{Nb} / \mathrm{Y}$ at a given $\mathrm{Zr} / \mathrm{Y}$ than $\mathrm{MORB}$ (that is, they have positive $\Delta \mathrm{Nb}$ calculated on a chondrite-normalized basis, relative to a reference line defined as zero separating MORB from Icelandic basalts) and that this was a characteristic of the Iceland plume head. MORB-source mantle has $\Delta \mathrm{Nb} \sim-0.5$ whereas modern Icelandic basalts have $\Delta \mathrm{Nb}>0$ (up to 0.8 ) and so $\Delta \mathrm{Nb}$ was developed as a tool for assessing whether lavas share a common source with Icelandic basalts (e.g. Fitton, et al, 1997). The apparent rarity of such a Nb-enriched signature in areas such as the BPIP was explained by means of a zoned plume head having an axial zone of Icelandic mantle surrounded by a thick outer shell of anomalously hot but compositionally normal N-MORB-source mantle (Fitton et al., 1997). Later studies showed that lavas with a range of negative to positive $\Delta \mathrm{Nb}$ are present throughout the ocean basins (Fitton, 2007; Natland, 2007) and consequently, positive $\Delta \mathrm{Nb}$ is not unique to Iceland. Natland 
(2007) argued that mixing between depleted basalt and petrogenetically unrelated mafic to silicic differentiates with an ultimate origin in ancient continental crust could adequately explain variability in $\triangle \mathrm{Nb}$ at Iceland.

Alternatively, the pyroxenite trace element composition given in Lambart (2017) has $\Delta \mathrm{Nb}=+0.33$ whereas North Atlantic depleted MORB source mantle has $\Delta \mathrm{Nb}=-0.5$ (Hole et al., 2015a). Consequently, melting of a hybrid peridotite-pyroxenite source could produce a range in $\Delta \mathrm{Nb}$ depending on the proportions of peridotite and pyroxenite contributing to the melt. At Baffin Island, Vaigat Formation lavas have $\Delta \mathrm{Nb}$ varying from -0.35 to $+0.30(\mathrm{~N}-$ type and E- type of Robillard et al., 1992) and there is a continuum of $\Delta \mathrm{Nb}$ values across that range. Lavas of the Enni Formation in the Faeroes (FIBG) have $\Delta \mathrm{Nb}=-0.13$ to +0.25 (Millett et al., 2017) with low-Ti 8 lavas generally having the most negative, and high-Tis lavas the most positive $\Delta \mathrm{Nb}$. Along the Reykjanes Ridge, $\Delta \mathrm{Nb}$ increases systematically toward Iceland from -0.5 at $60^{\circ} \mathrm{N}$ to +0.5 at $63^{\circ} \mathrm{N}$. This implies that the positive and negative $\Delta \mathrm{Nb}$ sources are closely related both in space, and rather than appealing to a plume head with a MORB-source carapace, we argue that the source of the variable $\Delta \mathrm{Nb}$ is local and an indication of the availability of pyroxenite in the mantle or silicic materials in the crust.

\section{Consideration of crustal thicknesses.}

Current models for magmatism at Iceland are partly constrained by the thickness of new crust that can be generated by decompression melting of peridotite or a mixed lithological source (e.g. Shorttle et al., 2013; 2014; Matthews et al., 2016; Lambart, 2017). Wide-angle seismic-reflection models (Darbyshire et al., 2000) suggest crustal thicknesses of $\sim 20 \mathrm{~km}$ for the northern half of the Northern Volcanic Zone (NVZ) whereas thicker crust $(24-30 \mathrm{~km})$ is found elsewhere in northern and central Iceland. The thickest crust $(37 \mathrm{~km})$ is found in central Iceland. Estimates from seismic receiver functions (Foulger et al., 2003) generally agree with those of Darbyshire et al. (2000) but suggest greater thicknesses of $\sim 30 \mathrm{~km}$ in the northern NVZ and $\sim 20 \mathrm{~km}$ in western Iceland.

For decompression melting, the rate of melt generation is controlled by the melt productivity of the lithology or lithologies undergoing melting whereas the rate of decompression is primarily proportional to the rate of mantle upwelling (Ito and van Keken, 2007; King and Adam, 2014). Shorttle et al. (2014) and Lambart (2017) argued that for a mixed pyroxeniteperidotite lithology at $\sim 1480^{\circ} \mathrm{C}$ passive plate spreading alone could generate the $\sim 20 \mathrm{~km}$ of crust at Iceland's coasts but that the thick crust (up to $40 \mathrm{~km}$ ) under central Iceland was strongly 
affected by enhanced melt production caused by plume-driven upwelling.

An alternative explanation is that the thicker crust under central Iceland results from $\sim 20 \mathrm{~km}$ of new crust generated on top of pre-existing crust of the same thickness. Both Foulger (2006) and Torsvik et al. (2015) concluded that continental crust beneath southeast Iceland is part of 350-km-long and 70-km-wide extension of the Jan Mayen Microcontinent (JMM). Consequently, any model for crustal generation in Iceland's rift zones need only account for a maximum of $20 \mathrm{~km}$ of new crust formation and does not require short wavelength variability in plume buoyancyflux to explain additional crustal thickness.

\section{Towards a new magmatic paradigm for the NAIP?}

The numerous complications associated with generating $\mathrm{T}_{\mathrm{P}}$ estimates based on olivine geothermometers and petrological methods means that for the NAIP $\mathrm{T}_{\mathrm{P}}>1500^{\circ} \mathrm{C}$ cannot be justified. This is mainly because there is insufficient petrographical and mineralogical data that accompanies published $\mathrm{T}_{\mathrm{P}}$ estimates to test or appraise their validity. Olivine accumulation and widespread disequilibrium between olivine, glass and whole-rock compositions renders most published $T_{P}$ determinations highly suspect. However, as documented here, careful examination of aphyric lavas from West Greenland might require $\mathrm{T}_{\mathrm{P}}>$ ambient and perhaps up to $1500^{\circ} \mathrm{C}$.

The high ${ }^{3} \mathrm{He} /{ }^{4} \mathrm{He}$ of some lavas has more than one explanation and does not necessary require a syn-magmatic deep source from a primordial mantle reservoir. The absence of a clear geochemical fingerprint of pyroxenite-dominated magmatism also suggests that the NAIP differs from other LIP such as Hawaii and Siberia. This means that magmatism in the NAIP does not conform to conventional plume models as applied to other LIP.

Nielsen et al. (2007) argued that an abrupt change from contractional intra-plate deformation to stress relaxation in the adjacent European continent produced sufficient pre-rupture tectonic stress to precipitate continental break-up in the North Atlantic without the need to invoke a thermal mantle plume as a driving mechanism. Hole et al. (2015a) noted that early magmatism in the NAIP occurred almost synchronously (61-62 Ma) in areas of thinned lithosphere that are now represented by the Labrador Sea and Rockall Trough. At that time, the Greenland lithospheric keel separated the two thinned areas. Inevitably, magmatism would have concentrated in areas of thinnest lithosphere, and so, at c. 62-58 Ma, the magmatic foci were in the west along the opening Labrador trough, and in the east along the Rockall Trough, extending through the Faeroe-Shetland Basin, and terminating in the Vøring Basin to the NE. The presence of small, but clearly identifiable, offshore igneous centres along the lineament from 
the Rockall Trough to the Vøring Basin (e.g. Archer et al., 2005; Jolley and Bell, 2002a, b; Hole et al., 2015a) encourages the hypothesis that these centres represent rift-flank volcanoes formed during initial rifting. If NAIP magmatism was a response to lithospheric extension and consequent decompression melting of mantle peridotite, then this accounts for the dominance of peridotite-derived magmas in the region. However, there is still a need for locally elevated mantle temperatures to explain the compositions and distribution of some of the early NAIP lavas and the very existence of modern Iceland.

The formation of a supercontinent causes the enlargement of flow wavelength and a subcontinental increase in temperature (Hole, 2015; Brandl et al., 2013; Coltice et al., 2007; 2009). This temperature increase may lead to large-scale melting without the involvement of plumes, and the temperature anomaly generated by such warming was wide and diffuse. It disappears with continental dispersal and would not leave a hotspot track on the seafloor (Coltice et al., 2007). Brandl et al. (2013) showed that basalts from the Atlantic Ocean that formed close to the margin of the rifted continent reveal an upper mantle temperature immediately after continental rifting that was up to $150^{\circ} \mathrm{C}$ higher than the present-day average and concluded that the Atlantic thermal anomaly was created by continental insulation and persisted in the mantle beneath the Atlantic Ocean for 10 s of millions of years after the continental fragments had dispersed.

The internal heating hypothesis has led to suggestions that there are two end members of continental flood basalts: (1) plume-derived continental flood basalts that are characterized by a very brief and high rate of magma supply over a restricted and radiating area followed by continuous hotspot activity; and (2) global warming-derived continental flood basalts that occur over a supercontinent and are characterized by wide and diffuse magmatism at a lower magma supply rate that disappears with continental dispersal. A key feature of internal heating of the mantle is that there is no continued flux of heat once continental break-up begins. Magmatism occurs in response to rifting, and as soon a decompression melting begins, thermal energy is lost generating melt. This energy cannot be replaced because internal heating is no longer effective after rifting has thinned the lithosphere and the insulating blanket has been removed. This lithospheric thinning must therefore result from plate boundary forces and is derived from the top-down (Anderson, 2005; Anderson and Natland, 2007; 2014).

For mantle at a given $\mathrm{T}_{\mathrm{P}}$ consisting of mixed lithologies the most fusible components will melt first. Pyroxenite derived from recycled subducted slabs has diverse melting behaviour and certain pyroxenites but not all have a lower solidus $\mathrm{T}$ at a given $\mathrm{P}$ than peridotite (Lambart, 2013). The volume of melt that is produced from a hybrid pyroxenite-peridotite source is 
therefore affected by the proportions of different lithologies in the source or entering the melt (Lambart, 2017). For Iceland, much isotopic variability in rift zone lavas has been explained by such a process (e.g. Thirlwall et al., 2004; Shorttle et al., 2013). Similarly, higher $\Delta \mathrm{Nb}$ might also express a greater proportion of pyroxenite in the source. In this case, excess melt production at modern

Iceland might reflect a greater proportion of fusible mantle than elsewhere in the NAIP. However, magmatism at Iceland might too require local excess temperature, but this could result from internal heating.

\section{Conclusions.}

The generation of magma in the NAIP does not necessarily require the existence of a longlived deep-seated mantle plume. Estimates of $T_{P}$ beneath the region have led to the erroneous assumption that such an origin is required. A detailed review of the different methods of determining $T_{P}$ for NAIP lavas, shows that many estimates are petrologically unsound because of difficulties in determining whether minerals and host-melts are in equilibrium, and others fail to address the importance of olivine accumulation. The commonly-held assumption that picrite lavas containing olivine with high Fo content require elevated $\mathrm{T}_{\mathrm{P}}$ is incorrect. Accumulation of olivine formed in shallow parts of a melting column may be ultra-magnesian (Fo >90.5) but do not require temperatures that are higher than olivines with lower Fo which are formed in deeper parts of the melting column. However, $\mathrm{T}_{\mathrm{P}}$ up to $1500^{\circ} \mathrm{C}$ may still be required for the generation of some lavas in West Greenland and Baffin Island, whereas there is little petrological evidence for $\mathrm{T}_{\mathrm{P}}>1450^{\circ} \mathrm{C}$ beneath modern Iceland.

In central Iceland, melting of peridotite or of a hybrid pyroxenite-peridotite source do not support geophysical crustal thickness estimates up to $40 \mathrm{~km}$ at any sensible $\mathrm{T}_{\mathrm{P}}$. Those estimates require pre-existing continental crust, which was probably mafic and about $20 \mathrm{~km}$ thick, to have existed before $15 \mathrm{Ma}$.

Unlike other LIPs, the NAIP lacks any clear evidence from the geochemistry of lavas and their component olivines for the involvement of large volumes of mantle pyroxenite in their petrogenesis. Other LIPS (e.g. Hawaii, Siberian Traps, Karoo) produce considerable volumes of lavas that are best interpreted as reaction pyroxenite-dominated melts formed during the recycling of oceanic lithosphere into the deep mantle. This negates the necessity for a deep (CMB) source for any of the NAIP magmas.

Local extensional tectonism resulting from plate boundary forces represents the most important control on the distribution of magmatism in the NAIP, with each period of 
magmatism being related to its own rifting event. Thus magmatism was widespread across the region.

Prior to continental break-up, continental insulation resulted in localized elevated mantle temperatures, and extension above this internally heated mantle drove melting. Because, unlike the case of other purported mantle plumes, internal heating does not provide a continual flux of heat, magmatism at any one location waned as melt was generated and consequently the mantle cooled at each one. 


\section{References cited}

Allègre, C. J., Turcotte, D. L., 1986. Implications of a two-component marble-cake mantle. Nature 323, 123-127.

Anderson, D.L., 1998. The helium paradoxes. Proc. Natl. Acad. Sci. USA 95, 4822-4827.

Anderson D.L., 2005. Scoring hotspots: the plume and plate paradigms. In: Foulger, G.R., Natland J.H., Presnall, D.C., Anderson D.L. (eds) Plumes, Plates and Paradigms. Geol. Soc. Am. Special Volume, 388.

Anderson D.L., 2007. Is there convincing tomographic evidence for whole mantle convection? http://www.mantleplumes.org/TomographyProblems.html

Anderson, D.L., 2013. The persistent plume myth. Aust. J. Earth Sci. 6, 657-673 Anderson, D.L., Natland, J.H., 2007. Evidence for mantle plumes? Nature 50, 7169.

Anderson, D.L., Natland, J.H., 2014. Mantle updrafts and mechanisms of oceanic volcanism. Proc. Nat. Acad. Sci. USA, 111, E4298-E4304.

Archer, S.A., Bergman, S.C., Illiffe, J., Murphy, C.M., Thorton, M., 2005. Palaeogene igneous rocks reveal new insights into the geodynamic evolution and petroleum potential of the Rockall Trough, NE Atlantic Margin. Basin Research 17, 171-201.

Ariskin, A.A., Nikolaev, G.S., 1996. An empirical model for the calculation of spinel-melt equilibria in mafic igneous systems at atmospheric pressure: 1, Chromian spinels. Contrib. Mineral. Petrol. $123,282-292$.

Beattie, P.D., Ford, C.E., Russell, D.G., 1991. Partition coefficients for olivine-melt and orthopyroxenemelt systems. Contrib. Mineral. Petrol. 109, 212-224.

Beattie, P.D., 1994. Systematics and energetics of trace-element partitioning between olivine and silicate melts: Implications for the nature of mineral/melt partitioning. Chem. Geol. 117, 57-71.

Beattie, P.D. 1995. Olivine-melt and orthopyroxene-melt equilibria. Contrib. Mineral. Petrol. 115, 103111.

Brandl, P.A., Regelous, M., Beier, C., Haase, K.M. 2013. High mantle temperatures following rifting caused by continental insulation. Nature Geosci. 6, 391-394.

Brandon, A.D., Graham, D.W., Waight, T., Gautason, B., 2007. ${ }^{186} \mathrm{Os}$ and ${ }^{187}$ Os enrichments and high ${ }^{3} \mathrm{He} /{ }^{4} \mathrm{He}$ sources in Earth's mantle; evidence from Icelandic picrites. Geochem. Cosmochim. Acta 71, 4570-4591.

Breddam, K., 2002. Kistufell: Primitive melt from the Iceland mantle plume. J. Petrol. 43, 345-373.

Bouhifd, M.A., Jephcoat, A.P., Heber, V.S., and Kelley, S.P., 2013. Helium in Earth's early core. Nature, Geosci. 6: 982-986.

Clague, D.A., Denlinger, R.P., 1994. Role of olivine cumulates in destabilizing the flanks of Hawaiian volcanoes. Bull. Volcanol. 56, 425-434.

Coltice, N., Phillips, B.R., Bertrand, H., Ricard, Y., Rey. P., 2007. Global warming of the mantle at the origin of flood basalts over supercontinents. Geology 35, 391-394. 
Coltice, N., Bertrand, H., Rey, P.M., Jourdan, F., Phillips, B.R., Ricard, Y., 2009. Global warming of the mantle beneath continents back to the Archaean. Gondwana Research 15, 254-266.

Coogan, L.A., Saunders, A.D., Wilson, R.N., 2014. Aluminium-in-olivine thermometry of primitive basalts: Evidence of an anomalously hot mantle source for large igneous provinces. Chem. Geol. 368, 1-10.

Courtillot, V., Davaille, A., Besse, J.,Stock, J., 2003. Three distinct types of hotspots in the Earth's mantle. Earth Planet. Sci. Lett. 205, 295-308

Dale, C.W., Pearson, D.G., Starkey, N.A., Stuart, F.M., Ellam, R.M., Larsen, L.M., Fitton, J.G., Macpherson, C.G., 2009. Osmium isotopes in Baffin Island and West Greenland picrites: Implications for the ${ }^{187} \mathrm{Os} /{ }^{188} \mathrm{Os}$ composition of the convecting mantle and the nature of high ${ }^{3} \mathrm{He} /{ }^{4} \mathrm{He}$ mantle. Earth Planet. Sci. Lett. 278, 267-277.

Dasgupta, R., Hirschmann, M.M., 2006. Melting in the Earth's deep upper mantle caused by carbon dioxide. Nature 440, 659-662.

Dasgupta, R., Hirschmann, M. M., Smith N. D., 2007. Partial melting experiments on peridotite+CO ${ }_{2}$ at $3 \mathrm{GPa}$ and genesis of alkalic ocean island basalts. J. Petrol. 48, 2093-2124.

Dasgupta, Mallik, A., Tsuno, K., Withers, A.C., Hirth, G., Hirschmann, M.M., 2013. Carbon-dioxiderich silicate melt in the Earth's upper mantle. Nature 493, 211-216. doi:10.1038/nature11731

Danyuschevsky, L.V., Plechov, P., 2011. Petrolog3: Integrated software for modeling crystallization processes. Geochem. Geophys. Geosys. 12. doi:10.1029/2011GC003516.

Darbyshire, F.A., Priestley, K.F., White, R.S., Stefansson, R., Gunmundsson, G.B., Jakobsdottir, S.S., 2000. Crustal structure of central and northern Iceland from analysis of teleseismic receiver functions. Geophys. J. Int. 143, 163-184.

Davis, W.M., 1889. Topographical development of the Triassic formation of the Connecticut Valley, Am. J. Sci. 37: 423-434.

Day, J.M.D., 2016. Evidence against an ancient non-chondritic mantle source for North Atlantic Igneous Province lavas. Chem. Geol. 440, 91-100.

Dickin, A.P., Jones, N.W., Thirlwall, M.F., Thompson, R.N., 1987. A Ce/Nd isotope study of crustal contamination processes affecting Paleocene magmas in Skye, Northwest Scotland. Contrib. Mineral.Petrol. 96, 455-464.

Drever, H.I., Johnston, R., 1959. XXII.-The Petrology of Picritic Rocks in Minor Intrusions - a Hebridean Group. Trans R. Soc. Edin. 63, 459-499.

Dygert, N., Jackson, C.R.M., R.M., Hesse, M.A., Tremblay, M.M., Shuster, D.L., and Gu, J.T., 2018. Plate tectonic cycling modulates Earths 3He/22Ne ratio. Earth Planet. Sci. Lett., 498: 309-321

Ellam, R.M., Stuart, F.M., 2004. Coherent $\mathrm{He}-\mathrm{Nd}-\mathrm{Sr}$ isotope trends in high ${ }^{3} \mathrm{He} /{ }^{4} \mathrm{He}$ basalts: implications for a common reservoir, mantle heterogeneity and convection. Earth Planet. Sci. Lett. 228, 511-523.

Elliott, T.R., Hawkesworth, C.J., Gonvold, K. 1991. Dynamic melting of the Iceland plume. Nature 351, 
201-205.

Fairbridge, R.W., Finkl, C.W., Jr., 1980. Cratonic erosional unconformities and peneplains. J. Geol. 88: 69-86.

Faithful, J.W., Timmerman, M.J., Upton, B.G.J., Rumsey, M.S., 2012. Mid-Eocene renewal of magmatism in NW Scotland: the Loch Roag Dyke. J. Geol. Soc. Lond. 169, 115-118.

Fitton, J.G., Saunders, A.D., Norry, M.J., Hardarson, B.S., Taylor R.N., 1997. Thermal and chemical structure of the Iceland plume. Earth Planet. Sci. Lett. 153, 197-208.

Foley, S.F., Yaxley, G.M., Rosenthal, A., Buhre, S., Kiseeva, E.S., Rapp, R.P., Jacob, D.E., 2009. The composition of near-solidus melts of peridotite in the presence of $\mathrm{CO}_{2}$ and $\mathrm{H}_{2} \mathrm{O}$ between 40 and 60 kbar. Lithos 112, 274-283.

Font, L., Davidson, J.P., Pearson, D.G., Nowell, G.M., Jerram, D.A., Ottley, C.J., 2008. Sr and Pb isotope micro-analysis of plagioclase crystals from Skye lavas: an insight into open-system processes in a flood basalt province. J. Petrol. 49, 1449-1471.

Foulger, G.R., 2006. Older crust underlies Iceland. Geophys J. Int. 165, 672-676. Foulger, G., 2012. Are 'hot spots' hot? J. Geodynamics 58, 1-28.

Foulger, G.R., Du, Z., Julian, B.R., 2003. Icelandic-type crust. Geophys. J. Int. 155, 567-590.

Foulger, G.R., Natland, J.H., Anderson, D.L., 2005, A source for Icelandic basalts in re melted Iapetus crust. J. Volcanol. Geotherm. Res. 141, 23-44.

Fowler, S.J., Bohrson, W.A., Spera, F.J., 2004. Magmatic evolution of the Skye Igneous Centre, western Scotland: Modelling of assimilation, recharge and fractional crystallization. J. Petrol. 45, 24812505 .

Francis, D., 1985. The Baffin Bay lavas and the value of picrites as analogues of primary magmas. Contrib. Mineral. Petrol. 89, 144-154.

Frey, A.F., Huang, S., Xu, G., Jochum, K.P., 2016. The geochemical components that distinguish Loaand Kea-trend Hawaiian shield lavas. Geochim. Cosmochim. Acta 185, 160-181.

Gaetani, G. 2016. The behaviour of $\mathrm{Fe}^{3+} / \Sigma \mathrm{Fe}$ during partial melting of spinel lherzolite. Geochim. Cosmochim. Acta 185, 64-77.

Garapic, G., Mallik, A., Dasgupta, R., Jackson, M.G., 2015. Oceanic lavas sampling the high $-{ }^{3} \mathrm{He} /{ }^{4} \mathrm{He}$ mantle reservoir: Primitive, depleted, or re-enriched? Am. Mineral. 100, 2066-2081.

Gazel, E., Hoernle, K., Carr, M.J., Herzberg, C, Saginor, I., van den Bogaard, P., Hauff, F., Feigenson, M., and Swisher III, C., 2011. Plume-subduction interaction in southern Central America: Mantle upwelling and slab melting. Lithos 121, 117-,134.

Graham, D.W., Hanan, B.B., Hemond, C., Blichert-toft, J., Albarede, F., 2014. Helium isotopic textures in Earth's upper mantle. Geochem. Geophys. Geosys. 15, 2048-2074.

Graham, D. W., Blichert-Toft, J., Russo, C. J., Rubin, K. H., Albarede, R., 2006. Cryptic striations in the upper mantle revealed by hafnium isotopes in southeast Indian ridge basalts. Nature 440, 199- 202. 
Green, D.H., Falloon,T.J., Eggines,S.M., Yaxley, G.M., 2001. Primary magmas and mantle temperatures. Eur. J. Mineral. 13, 437-451

Grove, T.L., Till, C.B., Krawczynski, M.J., 2012. The Role of H2O in subduction zone magmatism. Ann. Rev. Earth Planet. Sci. 40, 413-439.

Hammouda, T., Keshav, S. 2015. Melting in the mantle in the presence of carbon: Review of experiments and discussion on the origin of carbonatites. Chemical Geology, 418, 171-188.

Hansen, H., Pedersen A.K., Duncan, R.A., Bird, D.K., Brooks, C.K., Fawcett, J.J,, Gittims, J., Gotrton, M., O’Day, P. 2002. Volcanic stratigraphy of the southern Prinsen af Wales Bjerge region, East Greenland. In: Jolley, D.W. and Bell, B.R. (eds). The North Atlantic Igneous Province: Stratigraphy, Tectonic, Volcanic and Magmatic Processes. Geol Soc. Lond. Spec. Pub. 197, 183-218.

Hardarson, B.S., Fitton, J.G., Ellam, R.M., Pringle, M.S., 1997. Rift relocation - a geochemical and geochronological investigation of a palaeo-rift in northwest Iceland. Earth Planet. Sci. Lett. 153, 181-196.

Harðardóttir, S., Halldorsson, S.A., Hilton, D.R., 2018. Spatial distribution of helium isotopes in Icelandic geothermal fluids and volcanic materials with implications for location, upwelling and evolution of the Icelandic mantle plume. Chem. Geol. 480, 12-27.

Harker, A., 1908. The Natural History of Igneous Rocks. London (Methuen and Co.).

Hart, S.R., 1988. Heterogeneous mantle domains: signatures, genesis and mixing chronologies. Earth. Planet. Sci. Lett. 90, 273-296.

Heinonen, J.S., Carlson, R.W., Riley, T.R., Luttinen, A.V., Horan, M.F., 2014. Subduction-modified oceanic crust mixed with a depleted mantle reservoir in the sources of the Karoo continental flood basalt province. Earth Planet. Sci. Lett. 394, 229-241.

Herzberg, C. 2004. Partial Crystallization of Mid-Ocean Ridge Basalts in the Crust and Mantle. J Petrol.45, 2389-2405.

Herzberg, C. 2006. Petrology and thermal structure of the Hawaiian plume from Mauna Kea volcano. Nature, 444, 605-609.

Herzberg, C., 2011. Identification of source lithology in the Hawaiian and Canary Islands: implications for origins. J Petrol. 52, 113-146.

Herzberg, C., O’Hara, M.J. 2002. Plume-associated ultramafic magmas of Phanerozoic age. J. Petrol. 43, 1857-1883.

Herzberg, C., Asimow, P.D., 2008. Petrology of some oceanic island basalts: PRIMELT2.XLS software for primary magma calculation. Geochem. Geophys. Geosys. 9. Doi: 10.1029/2008GC002057.

Herzberg, C., Gazel, E. 2009. Petrological evidence for secular cooling in mantle plumes. Nature 458, 619-623.

Herzberg, C., Asimow, P.D., 2015. PRIMELT3 MEGA.XLSM software for primary magma calculation: Peridotite primary magma $\mathrm{MgO}$ contents from the liquidus to the solidus. Geochem. 
Geophys. Geosys. 16, 563-578.

Herzberg, C., Asimow, P.D., Arndt, N., Niu, Y., Lesher, C.M., Fitton, J.G., Cheadle, M.J., Saunders, A.D., 2007. Temperatures in ambient mantle and plumes: Constraints from basalts, picrites, and komatiites. Geochem. Geophys. Geosys. 8, 1-34.

Herzberg, C., Vidito, C., Salter, N., 2016. Nickel-cobalt contents of olivine record origins of mantle peridotite and related rocks. Am. Min. 101, 1952-1966.

Hirose, K., Kushiro, I., 1993. Partial melting of dry peridotites at high pressures: Determination of compositions of melts segregated from peridotite using aggregates of diamond. Earth Planet. Sci. Lett. 114, 477-489.

Hirschmann, M.M., 2000. Mantle solidus: Experimental constraints and the effects of peridotite composition. Geochem. Geophys. Geosys. 1. DOI: 10.1029/2000GC000070

Hirschmann, M. M., Kogiso, T., Baker, M. B., Stolper, E. M., 2003. Alkalic magmas generated by partial melting of garnet pyroxenite. Geology $31,481-484$.

Hirschmann, M.M., Tenner, T., Aubaud, C., Withers, A.C., 2009. Dehydration melting of nominally anhydrous mantle: The primacy of partitioning. Phys. Earth Planet. Int. 176, 54-68.

Hofmann, A.W., White, W.M., 1982. Mantle plumes from ancient oceanic crust. Earth Planet. Sci. Lett. 57, 421-436.

Hole M.J., 2015. The generation of continental flood basalt from decompression melting of internally heated mantle. Geology 43, 311-314.

Hole, M.J., 2018. Mineralogical and geochemical evidence for polybaric fractional crystallization of continental flood basalts and implications for identification of peridotite and pyroxenite source lithologies. Earth Sci. Rev. 176, 51-67.

Hole, M.J., Ellam, R.M., Macdonald, D.I.M., Kelley, S.P., 2015b. Gondwana break-up related magmatism in the Falkland Islands. J. Geol. Soc. Lond. 173, 108-126.

Hole, M.J., Millett, J.M., 2016. Controls of mantle potential temperature and lithospheric thickness on magmatism in the North Atlantic Igneous Province. J. Petrol. 57, 417-436.

Hole, M.J., Millett, J.M., Rogers, N.W., Jolley, D.W. 2015a. Rifting and mafic magmatism in the Hebridean basins. J. Geol. Soc. Lond. 172, 218-236

Hole, M.J., Saunders, A.D., 1996. The generation of small melt-fractions in truncated melt columns: Constraints from magmas erupted above slab windows and implications for MORB genesis. Min. Mag. 60, 173-189.

Horni, J.A., Hopper, J.R., Blischke, A., Geisler, W.H., Stewart, M., McDermott, K., Judge, M., Elerlendsson, O., Arting, U.E. 2016. Regional distribution of volcanism within the North Atlantic Igneous Province: In Peron-Pinvidic, G., Hopper, J. R., Stoker, M. S., Gaina, C., Doornenbal, J. C., Funck, T. and Arting, U.E. A Reappraisal of Crustal Structure, Tectonostratigraphy and Magmatic Evolution. Geol. Soc. Lond. Spec. Pub. 447, http://doi.org/10.1144/SP447.10 
Ito, G., van Keken, P.E., 2007. Hot Spots and Melting Anomalies. Treatise on Geophysics, 7, 371-435. Jackson, M.G., Konter, J.G., Becker, T.W. 2017. Primordial helium entrained by the hottest mantle plumes. Nature 542, 340-343.

Jamtveit, B., Brooker, R., Brooks, K., Larsen, L.M., Pedersen, T., 2001. The water content of olivines from the North Atlantic Volcanic Province. Earth Planet Sci. Lett. 186, 401-415.

Jennings, E.S., Holland, T.B.J., 2015. A simple thermodynamic model for melting of mantle peridotite in the system NCFMASOCr. J. Petrol. 56, 869-892.

Jennings, E.S., Holland, T.J.B., Shorttle, O., Mclennan, J., Gibson, S.A., 2016. The composition of melts from a heterogeneous mantle and the origin of ferropicrite: application of a thermodynamic model. J. Petrol. 57, 2289-2310.

Jolley, D.W., Bell, B.R., 2002a. The evolution of the North Atlantic Igneous Province and the opening of the NE Rift. In: Jolley, D.W. and Bell, B.R. (eds). The North Atlantic Igneous Province: Stratigraphy, Tectonic, Volcanic and Magmatic Processes. Geol. Soc. Lond. Spec. Pub. 197, $1-$ 13.

Jolley, D.W., Bell, B.R., 2002b. Genesis of the Erland Volcano, NE Altantic margin. In: Jolley, D.W. and Bell, B.R. (eds). The North Atlantic Igneous Province: Stratigraphy, Tectonic, Volcanic and Magmatic Processes. Geol. Soc. Lond. Spec. Pub. 197, 95-110.

Katz, R. F., Spiegelman, M., Langmuir, C.H. 2003. A new parameterization of hydrous mantle melting, Geochem. Geophys. Geosyst. 4. 1073, doi:10.1029/2002GC000433.

Keiding, J.K., Trumbull, R.B., Veksler, I.V., Jerram, D.A., 2011. On the significance of ultra-magnesian olivines in basaltic rocks. Geology 39, 1095-1098. DOI: 10.1130/G32214.1

Kempton, P.D., Fitton, J.G., Saunders, A.D., Nowell, G.M., Taylor, R.N., Hardarson, B.S., Pearson, G., 2000. The Iceland plume in space and time: a Sr-Nd-Pb-Hf study of the North Atlantic rifted margin. Earth Planet. Sci. Lett. 177, 255-271.

Kerr, A.C., Arndt, N.T. 2001. A note on the IUGS reclassification of the high-Mg and picritic volcanic rocks. J. Petrol. 42, 2169-2171. DOI: 10.1093/petrology/42.11.2169

Keshav, S., Gudfinnsson, G., Sen, G., Fei, S., 2004. High-pressure melting experiments on garnet clinopyroxenite and the alkalic to tholeiitic transition in ocean-island basalts. Earth. Planet. Sci. Lett. 223, 365-379.

King, S.D., Adam, C., 2014. Hotspot swells revisited. Phys. Earth Planet. Int. 235, 66-83.

Klein, E.M., Langmuir, C.H., 1987. Global Correlations of Ocean Ridge Basalt Chemistry with Axial Depth and Crustal Thickness. J. of Geophys. Res. 92, 8089-8115

Kogiso, T, Hirschmann, M.M., Frost, D.J., 2003. High-pressure partial melting of garnet pyroxenite: Possible mafic lithologies in the source of ocean island basalts. Earth Planet. Sci. Lett. 216, 603 617.

Kogiso, T., Hirschmann, M. M., Reiners, P. W., 2004. Length scales of mantle heterogeneities and their relationship to ocean island basalt geochemistry. Geochim. Cosmochim. Acta 68, 345-360. 
Kokfelt,T. F., Hoernle, K., Hauff, F., Fiebig, J.,Werner, R., Garbe-Schoenberg, D. 2006. Combined trace element and $\mathrm{Pb}-\mathrm{Nd}-\mathrm{Sr}-\mathrm{O}$ isotope evidence for recycled oceanic crust (upper and lower) in the Iceland mantle plume. J. Petrol. 47, 1705-1749.

Kornprobst, J., 1970. Peridotites and pyroxenites from Beni Bouchera (Morocco): An experimental investigation between 1100 and $1550{ }^{\circ} \mathrm{C}$, from 15 to 30 kilobars dry pressure. Contrib. Mineral. Petrol. 29, 290-309.

Kress, V.C., Carmichael, I.S.E., 1988. Stoichiometry of the iron oxidation reaction in silicate melt. Am. Mineral. 73: 1267-1274

Lambart, S. 2017. No direct contribution of recycled crust in Icelandic basalts. Geochem. Persp. Lett. 4, 7-12. doi: 10.7185/geochemlet.1728

Lambart. S., Baker, M.B., Stolper, E.M., 2016. The role of pyroxenite in basalt genesis: Melt-PX, a melting parameterization for mantle pyroxenites between 0.9 and 5GPa. J. Geophys. Res. doi: 10.1002/2015JB012762.

Lambart, S., Laporte, D., Provost, A., Schiano, P., 2012. Fate of pyroxenite-derived melts in the peridotitic mantle: thermodynamic and experimental constraints. J. Petrol. 53,451-476.

Lambart, S., Laporte, D., Provos, A., Schiano, P. 2013. Markers of the pyroxenite contribution in the major-element compositions of oceanic basalts: Review of the experimental constraints. Lithos 160- 161, 14-36.

Lambart, S, Laporte, D., Schiano, P. 2009. An experimental study of pyroxenite partial melts at 1 and

1.5 GPa: Implications for the major-element composition of Mid-Ocean Ridge Basalts. Earth Planet. Sci. Lett. 288. 335-347.

Larsen, L.M., Heaman, L.M., Creaser, R.A., Duncan, R.A., Frei, R., Hutchison, M., 2009. Tectonomagmatic events during stretching and basin formation in the Labrador Sea and the Davis Strait: evidence from age and composition of Mesozoic to Palaeogene dyke swarms in West Greenland. J. Geol. Soc. Lond. 166, 999-1012.

Larsen, L.M., Pedersen, A.K., 2000. Processes in high-Mg, high-T magmas: evidence from olivine, chromite and glass in Paleogene picrites from West Greenland. J. Petrol. 41,1071-1098.

Larsen, L.M., Pedersen, A.K., 2009a. Petrology of the Paleocene picrites and flood basalts on Disko and Nuussuaq, West Greenland. J. Petrol. 50, 1667-1711.

Larsen, L.M., Pedersen, A.K., 2009b. West Greenland was hot - how else can you make 22,000 km3 of picrites? http://www.mantleplumes.org/GreenlandHot.html

Larsen, L.M., Waagstein, R., Pedersen, A.K., Storey, M., 1999. Trans-Atlantic correlation of the Palaeogene volcanic successions in the Faeroe Islands and East Greenland. J. Geol. Soc. Lond. 156, 1081-1095.

Lawver, L.A., Müller, R.D., 1994. The Iceland hotspot track. Geology 22, 311-314.

Le Bas, M.J. 2000. IUGS reclassification of the high-Mg and picritic volcanic rocks. J. Petrol. 41, 14671470. DOI: 10.1093/petrology/41.10.1467. 
Le Maitre, R. W. (ed.) 2002. Igneous Rocks. A Classification and Glossary of Terms.

Recommendations of the International Union of Geological Sciences Subcommission on the Systematics of Igneous Rocks, 2nd ed. xvi + 236 pp. Cambridge, New York, Melbourne

Lee, C-T. A., Luffi, P., Plank, T., Dalton, H., Leeman, W.P., 2009. Constraints on the depths and temperatures of basaltic magma generation on Earth and other terrestrial planets using new thermobarometers for mafic magmas. Earth Planet. Sci. Lett. 279, 20-33.

Macdonald, G.A., 1949. Hawaiian petrographic province. Bull. Geol. Soc. Amer. 60, 1541-1596.

Maclennan, J., McKenzie, D.P., Gronvold, K., Shimuzu, N., Eiler, J.M., Kitchen, N. 2003. Melt mixing and crystallization under Theistareykir, northeast Iceland. Geochem. Geophys. Geosys. 4,86248664 doi:10.1029/2003GC000558.

Mallik, A., Dasgupta, R., 2013. Reactive Infiltration of MORB-Eclogite-Derived Carbonated Silicate Melt into Fertile Peridotite at 3GPa and Genesis of Alkalic Magmas. J. Petrol. 54, 2267-2300.

Matthews, S., Shorttle, O., Maclennan, J., 2016. The temperature of the Icelandic mantle from olivinespinel aluminum exchange thermometry. Geochem. Geophys. Geosys. 17, 4725-4752. doi:10.1002/2016GC006497.

Matzen, A.K., Baker, M.B., Beckett, J.R., Stolper, E.M., 2013. The temperature and pressure dependence of nickel partitioning between olivine and silicate melt. J. Petrol. 54, 2521-2545.

Matzen, A.K., Baker, M.B., Beckett, J.R., Wood, B.J., 2017. The effect of liquid composition on the partitioning of Ni between olivine and silicate melt. Contrib. Mineral. Petrol. 172. DOI 0.1007/s00410-016-1319-8.

McKenzie, D.P., Bickle, M.J., 1988. The volume and composition og melt generated by the estension of the lithosphere. J. Petrol. 29, 625-679.

McKenzie, D.P., O’Nions, R.K., 1995. The source region of Ocean Island basalts. J. Petrol. 36, 133159.

Meibom, A., Anderson, D.L., Sleep, N.H., Frie, R., Chamberlain, C.P., Hren, M.T., Wooden, J.L., 2003. Are high ${ }^{3} \mathrm{He} /{ }^{4} \mathrm{He}$ ratios in oceanic basalts an indicator of deep-mantle plume components? Earth. Planet. Sci. Lett. 208, 197-204.

Metrich, N., Zanon, V., Creon, L., Hledenbrand, A., Moreira, M. and Marques, F.O. 2014. Is the 'Azores Hotspot' a Wetspot? Insights from the Geochemistry of Fluid and Melt Inclusions in Olivine of Pico Basalts. J. Petrol. 55, 377-393.

Michael, P.J., 1988. The concentration, behavior and storage of $\mathrm{H}_{2} \mathrm{O}$ in the suboceanic upper mantle: Implications for mantle metasomatism. Geochim. Cosmochim. Acta 52, 555-566.

Millett, J.M., Hole, M.J., Jolley, D.W., Passey, S.R., 2017. Geochemical stratigraphy and correlation within large igneous provinces: The final preserved stages of the Faroe Islands Basalt Group. Lithos 286-287, 1-14.

Moreira, M., 2013. Helium isotopes and the two-reservoir mantle story. Geochem. Persp. 2, 244-266 Natland, J.H., 2003. Capture of helium and other volatiles during growth of olivine phenocrysts 
in picritic basalts from the Juan Fernandez Islands. J. Petrol. 44, 421-456.

Natland, J.H., 2007. $\Delta \mathrm{Nb}$ and the role of magma mixing at the East Pacific Rise and Iceland. Spec.

Pap. Geol. Soc. Am. 420, 413-449.

Natland, J.H. 2008a. Eruptive Temperatures of the Paleogene Picrites of West Greenland and Baffin Bayhttp://www.mantleplumes.org/Greenland.html

Natland, J.H. 2008b. Why olivine control arguments cannot be used to infer high temperature at Samoa. http://www.mantleplumes.org/CoolSamoa.html

Natland, J.H. 2009. West Greenland Glass in Picrite - Low-pressure Cotectic differentiates or Independent Compositions? http://www.mantleplumes.org/Greenland.html

Nichols, A.R.L., Carroll, M.R., Koskuldsson, A., 2002. Is the Iceland hot spot also wet? Evidence from the water contents of undegassed submarine and subglacial pillow basalts. Earth Planet. Sci. Lett. 202, 77-87.

Nikolaev, G.G. Ariskin, A.A. Barmina, G.S. 2018. SPINMELT-2.0: Simulation of Spinel-Melt Equilibrium in Basaltic Systems under Pressures up to 15 Kbar: II. Description of the Program Package, the Topology of the Cr-spinel-Melt Model System, and Petrological Implications. Geochem. Inter. 56, 125-135. DOI: 10.1134/S001670291802005

Nielsen, S.B., Stephenson, R.A., Thomsen, E. (2007). Dynamics of Mid-Palaeocene North Atlantic rifting linked with European intra-plate deformations. Nature 450, 1071-1074

O'Hara, M. J. 1968. The bearing of phase equilibria studies in synthetic and natural systems on the origin of basic and ultrabasic rocks. Earth Science Reviews 4, 69-133.

Parnell-Turner, R., White, N., Henstock, T, Murton, B., Maclennan, J., Jones, S.M., 2014. A continuous 55-million-year record of transient mantle plume activity beneath Iceland. Nature Geosci. 7 , 914- 919.

Parnell-Turner, R.E., White, N.J., Maclennan, J, Henstock, T.J., Murton, B.J., Jones, S.M., 2013. Crustal manifestations of a hot transient pulse at $60^{\circ} \mathrm{N}$ beneath the Mid-Atlantic Ridge. Earth Planet. Sci. Lett. 363, 109-120.

Peate, D.W., Baker, J.A., Blichert-Toft, J., Hilton, D.R., Storey, M. Kent, A.J.R., Brooks, C.K., Hansen, H., Pedersen, A.K., Duncan A.R., 2003. The Prinsen af Wales Njerge Formation lavas, East Greenland; the transition from tholeiitic to alkaline magmatism during Palaeogene continental break-up. J. Petrol. 44, 279-304.

Peate, D.W., Breddam, K., Baker, J.A., Kurz, M.D., Barker, A.K., Prestvik, T., Grassinaue, B., Skovgaard, C., 2010. Compositional Characteristics and Spatial Distribution of Enriched Icelandic Mantle Components. J. Petrol. 51, 1447-1475.

Pedersen, A.K., Larsen, L.M., Pedersen, G.K., 2017. Lithostratigraphy, geology and geochemistry of the volcanic rocks of the Vaigat Formation on Disko and Nuussuaq, Paleocene of West Greenland. Geol. Surv. Denmark and Greenland Bull. 39, 247pp. 
Péron, S., Moreira, M, Argranier, A., 2018. Origin of Light Noble Gases (He, Ne, and Ar) on Earth: A Review. Geochem. Geophys. Geosys. 19, 979-996.

Presnall, D.C., Gudfinnsson, G.H., 2011. Oceanic volcanism from the low-velocity Zone -without Mantle Plumes. J. Petrol. 52, 1533-1546.

Putirka, K.D. 2008a. Excess temperatures at ocean islands: Implications for mantle layering and convection. Geology, 36, 283-286.

Putirka, K.D., 2008b. Thermometers and barometers for volcanic systems. In: Putirka, K. D. and Tepley, F. J., III (eds) Minerals, Inclusions and Volcanic Processes. Min. Soc. Am., Rev. Mineral. Petrol. 69, 61-120.

Putirka, K.D., Perfit, M., Ryerson, F.J., Jackson, M.G., 2007. Ambient and excess mantle temperatures, olivine thermometry, and active vs. passive upwelling. Chem. Geol. 241, 177-206.

Rhodes. J.M., Dungan, M.A., Blanchard, D.P., Long, P.E., 1979. Magma mixing at mid-ocean ridges: evidence form basalts drilled near $22^{\circ} \mathrm{N}$ on the mid-Atlantic ridge. Tectonophys. 55:35-61

Roeder, P.L., Emslie, R.F., 1970. Olivine-liquid equilibrium. Contrib. Mineral. Petrol. 29, 275-289.

Robillard, I, Francis D., Ludden, J.N., 1992. The relationship between E- and N-type magmas in the Baffin Bay Lavas. Contrib. Mineral. Petrol. 112, 230-241.

Rosenthal, A., Yaxley, G.M., Crichton, W.A., Kovacs, I.J., Spandler, C., Hermann, J., Sandorne, J.K., Rose-Koga, E., Pelleter, A-A. 2018. Phase relations and melting of nominally 'dry' residual eclogites with variable $\mathrm{CaO} / \mathrm{Na}_{2} \mathrm{O}$ from 3 to $5 \mathrm{GPa}$ and 1250 to $1500{ }^{\circ} \mathrm{C}$; implications for refertilisation of upwelling heterogeneous mantle. Lithos, 314-315, 506-519.

Ryan, M.P., 1987. Neutral buoyancy and the mechanical evolution of magmatic systems. In: Magmatic Processes: Physiochemical Principles. 259-287.

Ryan, M.P., 1988. The mechanics and three-dimensional internal structure of active magmatic systems: Kilauea volcano, Hawaii. J. Geophys. Res. 93, B5, 4213-4248. 10.1029/JB093iB05p04213

Saal, A.E., Hauri, E.H., Langmuir, C.J., Perfit, M.J. 2002. Vapour undersaturation in primitive midocean-ridge basalt and the volatile content of earth's upper mantle. Nature 419, 451-455.

Sarafian, E., Gaetini, G.A., Hauri, E.H., Sarafian, A.R., 2017. Experimental constraints on the damp peridotite solidus and oceanic mantle potential temperature. Science 355, 942-945. DOI: 10.1126/science.aaj2165

Schiellerup, H. 1995. Generation and equilibration of olivine tholeiites in the northern rift zone of Iceland. A petrogenetic study of the Bláfjall table-mountain. J. Volcanol. Geotherm Res. 65, 161- 179. DOI: 10.1016/0377-0273(94)00116-X

Shorttle, O., Maclennan, J., Lambart, S., 2014. Quantifying lithological variability in the mantle. Earth Planet. Sci. Lett. 395, 24-40.

Shorttle, O., Maclennan, J., Piotrowski, A.M., 2013. Geochemical provincialism in the Iceland plume. Geochim. Cosmochim. Acta. 122, 363-397. DOI: 10.1016/j.gca.2013.08.032

Shorttle, O. Moussallam, Y. M., Hartley, M.E., Maclennan, J., Edmonds, M., Murton, B.J., 2015. Fe- 
XANES analyses of Reykjanes Ridge basalts: Implications for oceanic crust's role in the solid Earth oxygen cycle. Earth Planet. Sci. Lett. 427, 272-285.

Soager, N., Holm P.M., 2011. Changing compositions in the Iceland plume; Isotopic and elemental constraints from the Paleogene Faroe flood basalts. Chem. Geol. 280, 297-313.

Sobolev, A.V., Hofmann, A.W., Sobolev, S.V., Nikogosian, I.K., 2005. An olivine-free mantle source of Hawaiian shield basalts. Nature 434, 590-597.

Sobolev, A.V., Hofmann, A.W., Kuzmin, D.V., Yaxley, G.M., Arndt, N.T., Chung, S.-L., Danyushevsky, L.V., Elliott, T., Frey, F.A., Garcia, M.O., Gurenko, A.A., Kamenetsky, V.S., Kerr, A.C., Krivolutskaya, N.A., Matvienkov, V.V., Nikogosian, I.K., Rocholl, A., Sigurdsson, I.A., Sushchevskaya, N.M., Teklay, M., 2007. The amount of recycled crust in sources of mantle-derived melts. Science 316 412-417.

Sobolev, A.V., Krivolutskaya, N.A., Kuzmin, D., 2009. Petrology of the parental melts and mantle sources of Siberian trap magmatism. Petrology 17, 253-286.

Spice, H.E., Fitton, J.G., Kirstein, L.A., 2016. Temperature fluctuation of the Iceland mantle plume through time. Geochem. Geophys. Geosys. 17, 234-254.

Starkey, A.A., Stuart, F.M., Ellam, R.M., Fitton J.G., S, Basu, Larsen L. M., 2009. Helium isotopes in early Iceland plume picrites: constraints on the composition of high ${ }^{3} \mathrm{He} /{ }^{4} \mathrm{He}$ mantle. Earth Planet. Sci. Lett. 277, 91-100.

Starkey, N.A., Fitton, J.G., Stuart, F.M., Larsen, L.M., 2012. Melt inclusions in olivines from early Iceland plume picrites support high ${ }^{3} \mathrm{He} /{ }^{4} \mathrm{He}$ in both enriched and depleted mantle. Chem. Geol. $306,54-62$.

Stuart, F.M., Ellam, R.M., Harrop, P.J., Fitton, J.G., Bell, B.R., 2000. Constraints on mantle plumes from the helium isotopic composition of basalts from the British Tertiary Igneous Province. Earth Planet. Sci. Lett., 177, 273-285.

Stuart, F.M., Lass-Evans, S., Fitton, J.G., Ellam, R.M., 2003. High ${ }^{3} \mathrm{He} /{ }^{4} \mathrm{He}$ ratios in picritic basalts from Baffin Island and the role of a mixed reservoir in mantle plumes. Nature 424, 57-59.

Thirlwall, M.F., Gee, M.A.M., Taylor, R.N., Murton, B.J., 2004. Mantle components in Iceland and adjacent ridges investigated using double-spike $\mathrm{Pb}$ isotope ratios. Geochim. Cosmochim. Acta 68, 361-386.

Thompson, R.N., 1974. Primary basalts and magma genesis I: Skye, North-West Scotland. Contrib. Mineral. Petrol. 45, 317-341.

Thompson, R.N., 1982. Magmatism in the British Tertiary Volcanic Province. Scott. J. Geol. 18, 4907.

Thompson, R. N., Gibson, S.A. 2000. Transient high temperatures in mantle plume heads inferred from magnesian olivines in Phanerozoic picrites, Nature 407, 502-506.

Thompson, R.N., Gibson, I.L., Marriner, G.F., Mattey, D.P., Morrison, M.A., 1980. Trace element evidence of multistage mantle fusion and polybaric fractional crystallisation in the Palaeocene 
lavas of Skye, NW Scotland. J. Petrol. 21, 265-293

Thompson R.N., Dickin, A.P., Gibson, I.L., Morrison, M.A., 1982. Elemental fingerprints of isotopic contamination of Hebridean Palaeocene mantle derived magmas by Archaean Sial. Contrib.

Mineral. Petrol. 79, 159-168.

Thompson, R.N., Morrison, M.A., Dickin, A.P., Gibson, I.L., Harmon, R.S., 1986. Two contrasting styles of interaction between basic magmas and continental crust in the British Tertiary Volcanic Province. J. Geophys. Res. 91, 5985-5997.

Thomson, A., Maclennan, J., 2013. The distribution of olivine compositions in icelandic basalts and picrites. J. Petrol. 54, 745-768. DOI: 10.1093/petrology/egs083

Toplis, M.J., 2005. The thermodynamics of iron and magnesium partitioning between olivine and liquid: criteria for assessing and predicting equilibrium in natural and experimental systems. Contrib. Mineral. Petrol. 149, 22-39.

Torsvik, T.H., Amundsen, H.E.F., Trønnes, R.G., Doubrovine, P.V., Gaina, K., Kusznir, N.J., Steinberger, B., Corfu, F., Ashwal, L.D., Griffin, W.L., Werner, S.C., Jamtveit, B., 2015. Continental crust beneath southeast Iceland. Proc. Nat. Acad. Sci. USA 112, E1818-1827.

Trela, J., Gazel, E., Sobolev, A.V., Moore, L., Bizimis, M., Jicha, B., Batanova, G., 2017. The hottest lavas of the Phanerozoic and the survival of deep Archean reservoirs. Nature Geoci. 10, 451457. DOI: 10.1038/NGEO2954

Villiger, S., Ulmer, P., Muntener, O., Thompson, B., 2004. The liquid line of descent of anhydrous, mantle-derived, tholeiitic liquids by fractional and equilibrium crystallization —an experimental study at 1.0 GPa. J. Petrol. 45, 2369-2388.

Villiger, S., Ulmer, P., Muntener, O., 2007. Equilibrium and fractional crystallization experiments at $0.7 \mathrm{Gpa}$; the effect of pressure on phase relations and liquid compositions of tholeiitic magmas. J. Petrol. 48, 159-184.

Waight, T.E., Baker, J.A., 2012. Depleted basaltic lavas from the proto-iceland plume, central East Greenland. J. Petrol. 53, 1569-1596. 


\section{Figure captions.}

Fig. 1. (a) Reconstruction of the North Atlantic region at about 65 Ma showing the locations referred to in the text. Pecked lines labelled A6 etc., are seafloor magnetic anomalies. Black dots numbered 55-70 are plume-head positions at the time indicated and are taken from Lawver and Muller (1994). JMFZ, Jan Mayen Fracture Zone; SFZ, Svalbard Fracture Zone; GFZ, Greenland Fracture Zone; BPIP, British Palaeocene Igneous Province. After Hole and Millett (2016). (b) detail of the British Palaeocene Igneous Province showing the position of the main magmatic centres mentioned in the text and the main structural features of the region. After Hole et al. (2015).

Fig. 2. a) P-T diagram illustrating the generation of primary melt by decompression melting of dry peridotite. The dry solidus (red curve), olivine liquidus (green lines; $\mathrm{L}+\mathrm{Ol}$ ) and $\mathrm{MgO}$ isopleths (blue lines indexed for $\mathrm{MgO}$ content) were all calculated using the equations given in Herzberg and Asimow (2015). Garnet-in and spinel-out (pecked lines) are taken from McKenzie and O'Nions (1993). The two adiabats (thick dotted lines) are for $1350^{\circ} \mathrm{C}$ (MORB) and $1500^{\circ} \mathrm{C}$ for a continental LIP and are continued to $0 \mathrm{GPa}$ (fine pecked lines) for reference. The melting interval is indicated by the vertical arrows between $\mathrm{P} i$ (red dots) and $\mathrm{P} f$ (blue dots). Small coloured dots are PRIMELT3 primary magma solutions for glasses from Iceland (Kistufel, Herdubreidatogl and Borgarhraun; Thomson and Maclennan, 2011) and aphyric lavas from Unit 405 Annaanaa Member, Vaigat formation, Disko Island (Pedersen et al., 2017). $\mathrm{P} f$ and $\mathrm{T}_{\mathrm{Ol}}$ calculated using the method of Hole and Millett (2016).

Fig. 3. Compilation of various peridotite solidi and decompression melting pathways taken from the literature. a) dry peridotite solidi with adiabats for $1350^{\circ}-1600^{\circ} \mathrm{C}$ indicated (orange lines) and the adiabat for $\mathrm{T}_{\mathrm{P}}=1480^{\circ} \mathrm{C}$ as suggested by Matthews et al. (2016) for Iceland (black line). The olivine liquidus associated with $\mathrm{T}_{\mathrm{P}}=1480^{\circ} \mathrm{C}$ (black curve ' $\mathrm{H}$ and A') is that of Herzberg and Asimow (2015). Approximate pressure of intersection of each dry solidus with the $1480^{\circ} \mathrm{C}$ adiabat and the approximate $\mathrm{T}_{\mathrm{P}}$ required for intersection of each solidus at $3.5 \mathrm{GPa}$ are indicated. The garnet-spinel transition is taken from McKenzie and O'Nions (1993). b) Dry and 'damp' solidi of Sarafian et al. (2017) with $450 \mathrm{ppm}$ $\mathrm{H}_{2} \mathrm{O}$ on the damp solidi indicated in blue and the blue dots are the T-P conditions at 2.8 GPa. Pecked lines are extrapolations to higher pressures that the melting experiments. Red lines are estimates for the addition of $\mathrm{H}_{2} \mathrm{O}$ to the Herzberg and Asimow (2015) solidus, as described in the text; c) dry solidus of Hirschmann (2000) with 0 to $25 \mathrm{wt} \% \mathrm{CO}_{2}$, calculated at $>2.0 \mathrm{GPa}$ using the method of Dasgupta et al. $(2007 ; 2013)$. Note that at pressure $<2.0 \mathrm{GPa}, \mathrm{CO}_{2}$ is present as carbonate (the carbonate ledge of Hammoud and Keshav, 2015) whereas at higher pressures carbonatitic melts can most likely be produced and impregnate the surrounding mantle through metasomatism. The Dasgupta et al. (2007; 2013) model applies only to this deeper region. The blue line is the peridotite $+450 \mathrm{ppm} \mathrm{H}_{2} \mathrm{O}$ solidus from $b)$.

Fig. 4 Schematic representation of melting domains, represented by simple 1-D columns, for the two 
primary magmas shown in Fig. 1 formed at $\mathrm{T}_{\mathrm{P}}=1350$ and $1500^{\circ} \mathrm{C}$ representing $\sim 19$ and $\sim 14 \%$ melt based on a melt production rate of $12^{\circ} \mathrm{CGPa}^{-1}$ (Herzberg and Asimow 2015; Hole and Millett 2016). Small dots are the compositions of instantaneous melts formed at the pressure indicated, indexed for garnet lherzolite (pink) spinel-garnet transition (purple) and spinel lherzolite at $\mathrm{T}_{\mathrm{P}}=1500^{\circ} \mathrm{C}$ (light green) $\mathrm{T}_{\mathrm{P}}=1350^{\circ} \mathrm{C}$ (deep green). Large coloured dots are model primary magmas representing accumulated melt fractions at the pressure indicated and are based on Siqueiros Fracture Zone MORB and Baffin Island samples 100156 and BI/CS/19 (Herzberg and Asimow, 2015; Hole and Millett, 2016). Shaded triangular regions represent possible compositions of accumulated fractional melts that might form at $1350^{\circ} \mathrm{C}$ and $1500^{\circ} \mathrm{C}$, over the range of pressures indicated. Fo content and crystallization temperature of the olivine $\left(\mathrm{T}_{\mathrm{Ol}}\right)$ at the pressure indicated were calculated using the equations of Herzberg and Asimow (2015).

Fig. 5. Schematic representation of the pressure, temperature and composition $(\mathrm{P}, \mathrm{T}, \mathrm{X})$ relationships for the crystallization of a primary magma formed at $\mathrm{T}_{\mathrm{P}}=1500^{\circ} \mathrm{C}$ with $17.5 \mathrm{wt} \% \mathrm{MgO}$ representing $\sim 19 \%$ melt for a pressure range of 0 to $2.0 \mathrm{GPa}$. The black dots represent the approximate Fo content $(\mathrm{Mg \#})$ of olivine that crystallizes at the $\mathrm{Ol}+\mathrm{Cpx}+\mathrm{L}$ cotectic, and the grey dots the same for the $\mathrm{Ol}+$ $\mathrm{Cpx}+\mathrm{Pl}+\mathrm{L}$ cotectic. \% figures on the arrows are the approximate \% of olivine that can crystallize on the $\mathrm{Ol}+\mathrm{L}$ liquidus at a given pressure before reaching the $\mathrm{Ol}+\mathrm{Cpx}+\mathrm{L}$ cotectic. The grey shaded area is the region for crystallization of $\mathrm{L}+\mathrm{Ol}$ for a MORB primary magma. Modified from Hole (2018).

Fig. 6. Rhodes diagrams for olivine-glass or whole-rock equilibria for a) Baffin Island and selected samples from Iceland; b) Disko Island. Solid curve and two pecked lines are for $\mathrm{k}_{\mathrm{D}(\mathrm{Mg}-\mathrm{Fe})}{ }^{\mathrm{Ol} / \mathrm{L}}=0.30 \pm 0.03$. c) Illustration of the relationship between the Fo content of olivine and crystallization temperature for Petrolog3 (Danyuschevsky and Plechov, 2011) forward models of experimentally produced melt of mantle peridotite KR4003 (Walter, 1998). Black diamonds represent compositions at which plagioclase joins the crystallizing assemblage and white diamonds augite joins the assemblage. The approximate $T_{P}$ relating to each experiment is indicated, and a forward model for a MORB primary magma (Herzberg and Asimow, 2015) is shown for reference. The three large dots are $\mathrm{T}_{\mathrm{Ol}}$ determinations for Icelandic glasses. Data for Herdubreidatogl and Kistufel glasses suggest that they fall along olivine liquidus but that for Gaesafjoll requires crystallization of $\mathrm{L}+\mathrm{Ol}+\mathrm{Pl}$ (Appendix 3).

Fig. 7. Cr\# versus Mg\# for spinel in Siqueiros Fracture Zone MORB glasses (PetDB database), NAIP lavas and Gorgona komatiite (Georoc) and Tortugal picrites (Trela et al., 2017). Crosses labelled 'Primary $\mathrm{Cr}$-spinel' are ranges of $\mathrm{Mg} \#$ and $\mathrm{Cr} \#$ of spinels crystallizing from near primary magmas from Gorgona komatiites and MORB calculated from SPINMELT-2.0.

Fig. 8. a) $\mathrm{T}_{\mathrm{Sp}}$ and b) $\mathrm{T}_{\mathrm{Ol-Sp}}$ versus Cr\# for natural and model Cr-spinels. In a) $\mathrm{T}_{\mathrm{Sp}}$ was calculated using SPINMELT-2.0 for model primary magmas from Iceland, Baffin Island and the BPIP with variable $\mathrm{Cr}_{2} \mathrm{O}_{3}$ content and at $0.0 \mathrm{GPa}$ and $1.0 \mathrm{GPa}$ as indicated. $f \mathrm{O}_{2}$ was calculated using the parameterizations 
of Kress and Carmichael (1988) - see text for details. The inset shows vectors for the effects of variable pressure, $f \mathrm{O}_{2}$ and $\mathrm{Cr}_{2} \mathrm{O}_{3}$ content on a $\mathrm{Cr}$-spinel $(\mathrm{Cr} \#=50)$ that crystallized from a primary magma at $1150^{\circ} \mathrm{C}$. In b) $\mathrm{T}_{\mathrm{Ol}-\mathrm{Sp}}$ and $\mathrm{Cr} \#$ of natural Cr-spinels is taken from from Matthews et al., 2016, Trela et al., 2017, Spice et al., 2016 and Coogan et al., 2014. The pecked line at $1300^{\circ} \mathrm{C}$ and the diagonal line are for reference only.

Fig. 9. a) $\mathrm{FeO}(\mathrm{wt} \%$ ) and b) $\mathrm{CaO}$ (wt\%) versus $\mathrm{MgO}$ (wt\%) illustrating the relationships between olivine crystallization and melt composition. In a) The red line is the peridotite solidus and the pink shaded area encompasses compositions of primary melts of peridotite for melt fractions between the solidus and F $\sim 0.5$ (Herzberg and Asimow, 2008). Grey lines are isopleths with the Fo content of olivine indicated and are taken from Herzberg and Asimow (2008). All primary magmas derived from the melting of dry peridotite should fall within the pink shaded region (and also in diagram b). Primary magma 1 represents the composition generated by back-tracking from Etendeka lava JVT-09-32 (Keiding et al., 2011) along the orange pecked line for a target olivine Fo93.5 is reached, and primary magma 2 the same but for olivine Fog2 $_{92}$ Primary magma 3 results from addition of equilibrium olivine (grey pecked curve) to a MORB glass with $8 \mathrm{wt} \% \mathrm{MgO}$ which lies along the $\mathrm{L}+\mathrm{Ol}+\mathrm{Pl}$ cotectic with a target olivine of $\mathrm{Fo}_{91.7}$. Primary magma 4 results from the addition of equilibrium olivine (green

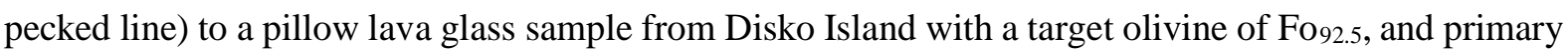
magma 5 the same for a target olivine of Fo91.0. The vertical pecked line and small red dots associated with primary magma 2 represent melt droplets which might contribute to the accumulated melt fraction. Individual melt droplets would be able to crystallize olivine with Fo up to 93.5, and these olivines might be present in the accumulated fractional melt or other melts formed thererafter. Grey dots represent the composition of melt inclusions in ultra-magnesian olivine (Fo92.0-93.3) in Etendeka picrite JVT-09-32 which was formed by melting of peridotite at $\mathrm{T}_{\mathrm{P}} \sim 1500^{\circ} \mathrm{C}$ (Keiding et al., 2011). Data for pillow lava glasses from Baffin Island (blue dots; Francis 1985; Robillard et al., 1992) and Disko Island (green dots; Larsen and Pedersen, 2000) and lavas from the Etendeka province (orange dots) are also shown. Grey diamonds represent glass compositions for MORB from the Siqueiros Fracture Zone, the black diamond the model primary magma to Siqueiros Fracture Zone MORB from Herzberg and Asimow (2015). The pecked black line is the LLD for Siqueiros Fracture Zone MORB calculated using Petrolog3 (Hole, 2018; Danyuschevsky and Plechov, 2011). Solid green lines illustrate the effect of accumulation of olivine of the Fo content indicated in a sample at the end of the liquid + olivine LLD for Siqueiros Fracture Zone MORB. The three black dots are the PRIMELT3 solutions for the glass plus accumulative olivine with their temperatures indicated. In b) the pink shaded areas is the approximate range of melt compositions derived from primary magmas of peridotite KR4003. Model primary magmas generated by olivine back-tracking that fall outside the pink envelope are considered to be invalid compositions. Green crosses labelled 3, 5, 7 GPaare the positions of primary melts of KR4003 at the pressure indicated. Pecked black lines are schematic crystallization trajectories for a primary 
magma formed at $\sim 4 \mathrm{GPa}$ crystallizing near the surface $(0 \mathrm{GPa})$ and at $\sim 1.5 \mathrm{GPa}$ (from Hole, 2018). The solid black line dividing peridotite and pyroxenite is from Herzberg and Asmow (2008). Light blue and light green dots are for Baffin Island and Disko Island respectively whole rock data for the glass data shown by the darker blue and green dots.

Fig. 10. a) $\mathrm{FeO}$ versus $\mathrm{MgO}$ and b) $\mathrm{MgO} / \mathrm{Al}_{2} \mathrm{O}_{3}$ versus $\mathrm{Mg} \#$ for selected glasses and whole-rock samples from Blafjall (Schiellerup, 1995). In a) grey lines are isopleths for olivine of the Fo content indicated and pecked black lines are vectors for the effects of the addition of olivine Fo ${ }_{86}$ to various Blafjall glasses. The LLD for a typical MORB primary magma is shown for reference. Legend on b) except crosses glasses from Kistufel and Herdubreidatogl (Thompson and Maclennan, 2011) that are likely to lie along the olivine liquidus. In b) the grey pecked line represents the boundary between glasses on the olivine liquidus (above the line) and those on the $\mathrm{L}+\mathrm{Pl}+\mathrm{Ol}$ cotectic (below the line). Pecked black lines are trajectories for the addition of olivine of the Fo content indicated to a glass of the composition shown at the lowest $\mathrm{MgO} / \mathrm{Al}_{2} \mathrm{O}_{3}$ values at the end of the lines. Crosses on olivine addition trajectories are for $1 \%$ addition of olivine and the highest $\mathrm{MgO}$ glass in the $\mathrm{BII}$ suite $(11 \mathrm{wt} \% \mathrm{MgO})$ is indicated. Note that the $\mathrm{Mg} \#$ of the $\mathrm{L}+\mathrm{Ol} \mathrm{LLD}$ for primary magmas increases with decreasing temperature because the mean $\mathrm{FeO}$ content is decreases at a faster rate than $\mathrm{MgO}$ with decreasing mean pressure of melting.The details of construction of $b$ ) are given in electronic Appendix 2.

Fig. $11 \mathrm{SiO}_{2} / \mathrm{FeO}$ versus $\mathrm{Mg} \#$ for isotopically uncontaminated $\left(\varepsilon_{\mathrm{N}} \mathrm{Nd}_{\mathrm{T}}>5\right)$ lavas from the Vaigat Formation (grey dots) and Maligat Formation (white dots) from Disko Island and aphyric lavas (black dots) from Unit 405, (Anaanaa Member, Vaigat Formation). Data from Pedersen et al (2017) and Larsen and Pedersen (2009a). The thick black curve id the LLD for a model primary magma to a Unit 405 lava and was generated using Petrolog3. Large white diamonds represent experimentally-generated primary magma compositions from melting of peridotite $\mathrm{KR} 4003$ at $3.0-4.5 \mathrm{GPa}$ and at $\mathrm{T}_{\mathrm{P}} \sim 1470-1600^{\circ} \mathrm{C}$, the lowest $\mathrm{SiO}_{2} / \mathrm{FeO}$ melts being those generated at the highest temperature. Grey diamonds are glasses from the Siqueiros Fracture Zone and the LLD for those samples was produced using Petrolog3 on a model MORB primary magma composition (Herzberg and Asimow, 2015). Pecked lines are mixing curves for the accumulation of olivine Fo88 in MORB cotectic glasses (grey diamonds with black rim) and each line stopped when a PRIMELT3 solution can no longer be generated. The stippled area therefore represents the locus of picritic lavas that could be formed at ambient $\mathrm{T}$ by the accumulation of olivine.

Fig. 12. a) Molecular projection from or towards diopside onto the plane Fo-Qz-CaTs (ForsteriteQuartz-Calcium Tschermakite) showing the areas occupied by stage 1, silica-deficient (SD - orange field) and silica-enriched (SE - blue field) pyroxenites. The pyroxene-garnet plane (represented by the red pecked line) is used for taxonomical purposes to identify high- (SE) and low-SiO 2 (SD) pyroxenites on the $\mathrm{SiO}_{2}$-rich and -poor sides, respectively. SE pyroxenites are formed by the transformation of basaltic oceanic crust to quartz or coestite eclogite, whereas cumulates in the same 
crust will form SD pyroxenite $(\mathrm{Ol}+\mathrm{Cpx}+\mathrm{Gt})$. Pyroxenites formed in the upper mantle and Transition Zone by the solid-state reaction of MORB with fertile peridotite (stage 2 pyroxenites) have compositions that are coincident with the Diopside-Enstatite-CaTs plane (Herzberg, 2011). Blue lines are cotectics for $\mathrm{L}+\mathrm{Cpx}+\mathrm{Gt} \pm \mathrm{Opx} \pm \mathrm{Cpx}$ at the pressures indicated in blue. After Herzberg (2011). b) the same diagram as in a) but showing the projection of melt compositions produced during melting experiments on a range of SD pyroxenites. Projection codes in mole\% are from O'Hara (1968); $\mathrm{Ol}=0 \cdot 5\left(\mathrm{Al}_{2} \mathrm{O}_{3}+\mathrm{FeO}+\mathrm{MnO}+\mathrm{MgO}\right)-0 \cdot 5\left(\mathrm{CaO}+\mathrm{Na}_{2} \mathrm{O}+\mathrm{K}_{2} \mathrm{O}\right)+1.75 \mathrm{P}_{2} \mathrm{O}_{5} ; \mathrm{CaTs}=$ $\mathrm{TiO}_{2}+\mathrm{Al}_{2} \mathrm{O}_{3}+\mathrm{Na}_{2} \mathrm{O}+\mathrm{K}_{2} \mathrm{O} ; \mathrm{Qz}=\mathrm{SiO}_{2}+\mathrm{TiO}_{2}\left(0.5 \mathrm{Al}_{2} \mathrm{O}_{3}\right)-0 \cdot 5(\mathrm{FeO}+\mathrm{MnO}+\mathrm{MgO})-1 \cdot 5 \mathrm{CaO}-$ $4.5\left(\mathrm{Na}_{2} \mathrm{O}+\mathrm{K}_{2} \mathrm{O}\right)+5.25 \mathrm{P}_{2} \mathrm{O}_{5}$

Fig. 13. P-T diagram showing the solidi of the pyroxenites in Fig. 12. Calculated using Melt-PX (Lambart et al., 2016).

Fig. 14. Diagrams of $T_{P}$ versus crustal thickness calculated using Melt-PX (Lambart et al., 2016) for a) melting of $100 \%$ peridotite for different solidi, including 'damp' solidi of Sarafian et al. (2017) with 200 and 450 ppm $\mathrm{H}_{2} \mathrm{O}$ (S-200 and S-450 respectively); b) melting a mixture of peridotite and pyroxenite KG1 along the Hirschmann (2000) solidus. Melting of $80 \%$ peridotite and $20 \%$ pyroxenite along the Sarafian et al. (2017) damp solidus with $450 \mathrm{ppm}_{2} \mathrm{O}$ is shown by the black shaded area. 


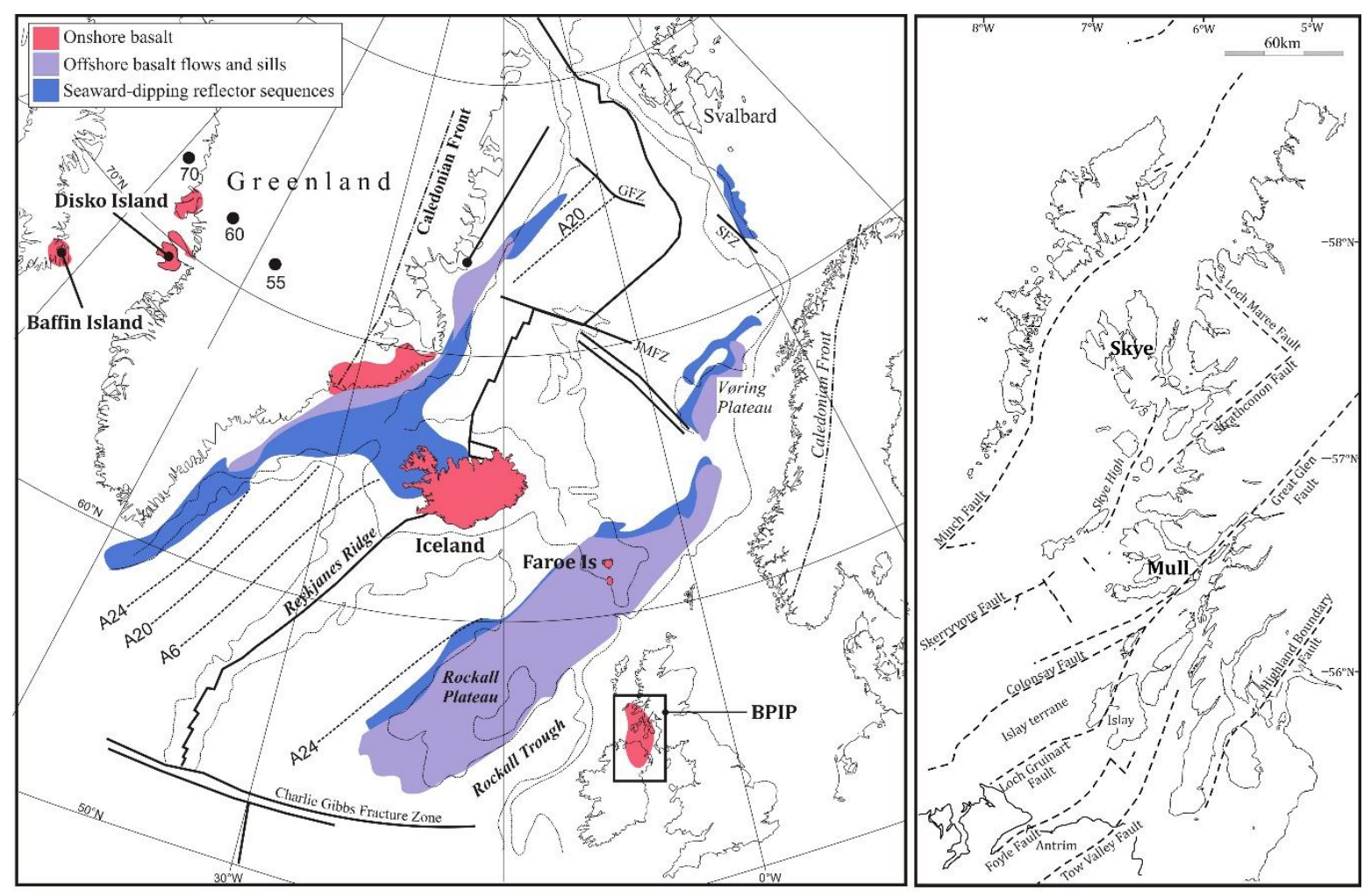

Hole \& Natland Fig. 1 


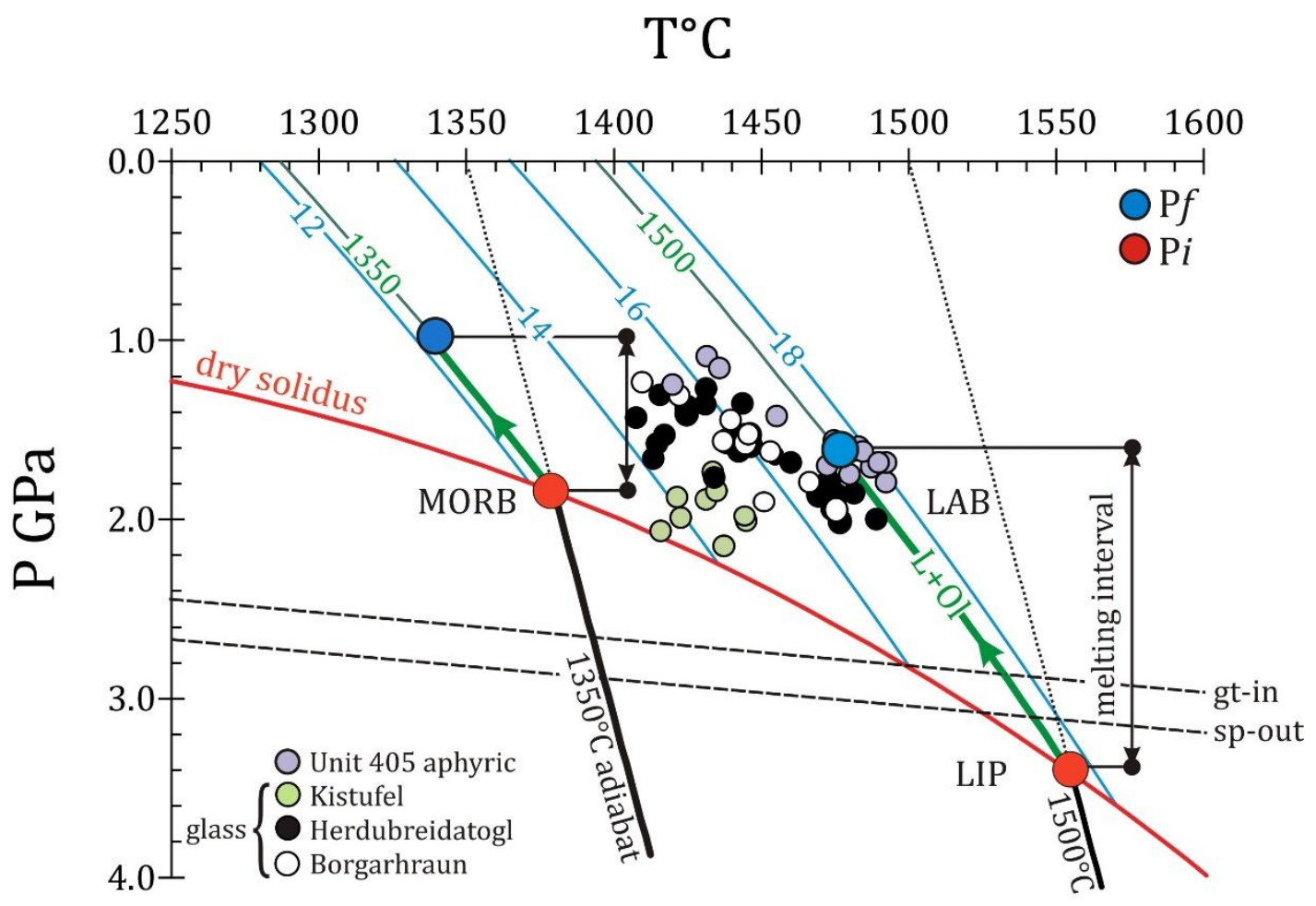

Hole \& Natland Fig. 2 


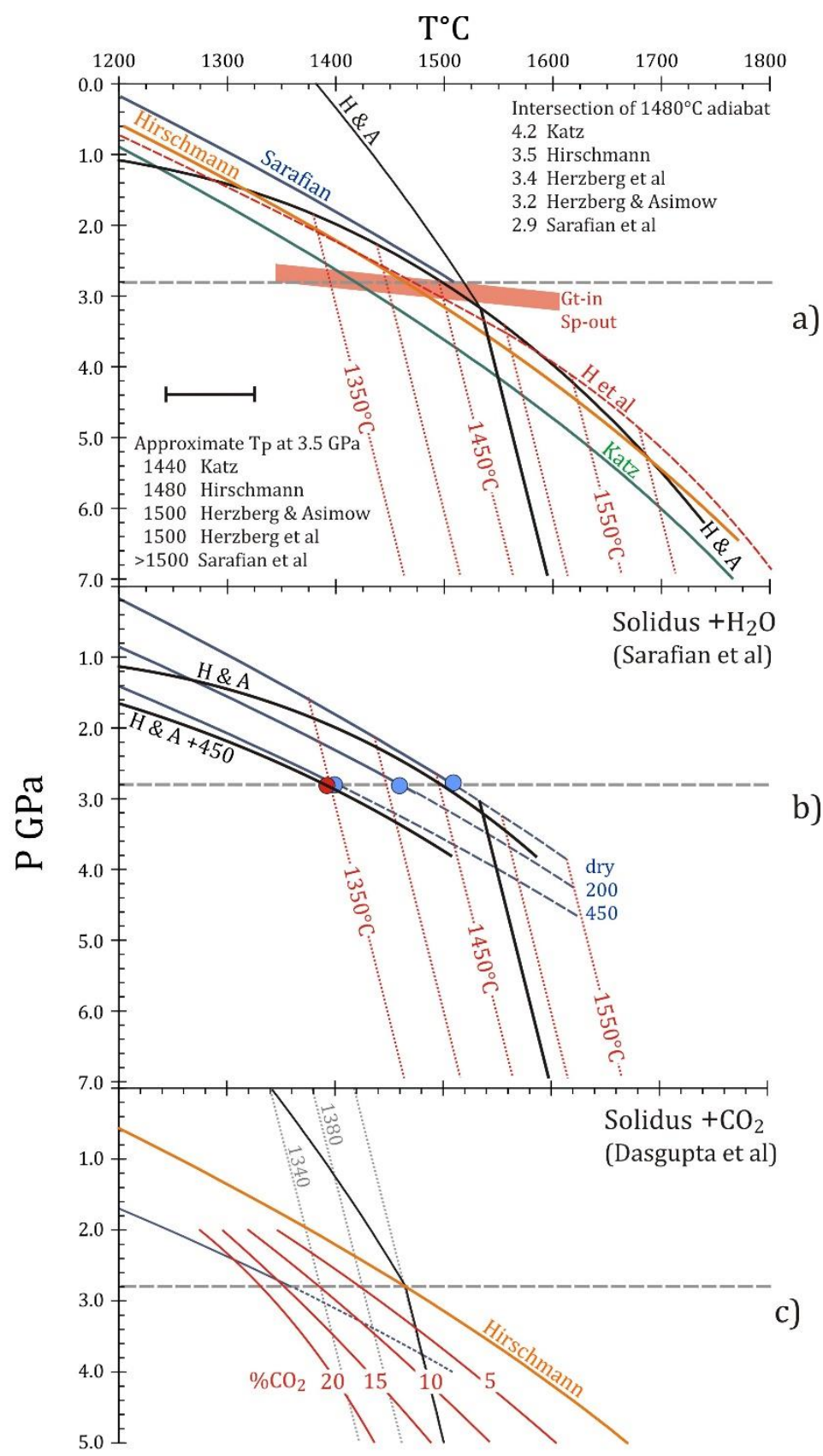

Hole \& Natland Fig. 3 


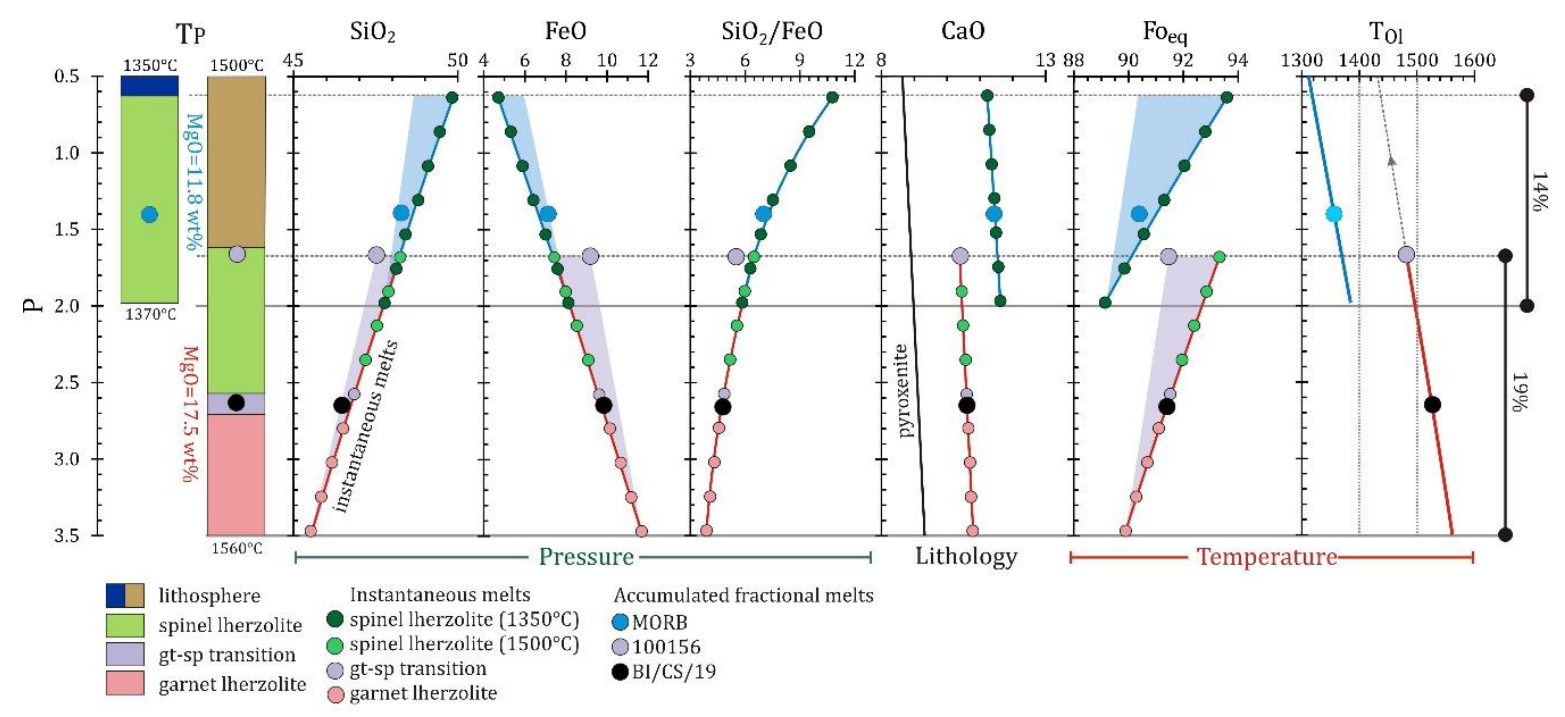

Hole \& Natland Fig. 4 


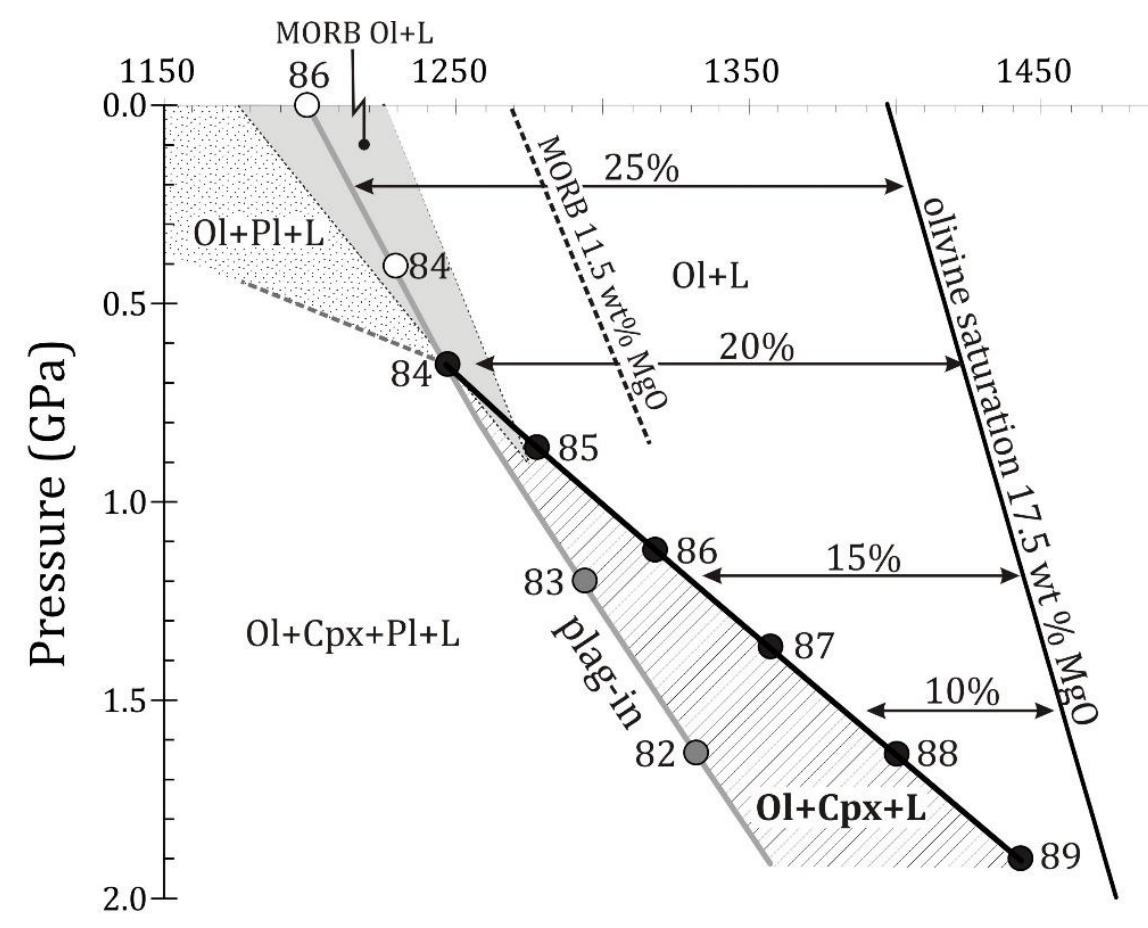

Hole \& Natland Fig. 5 

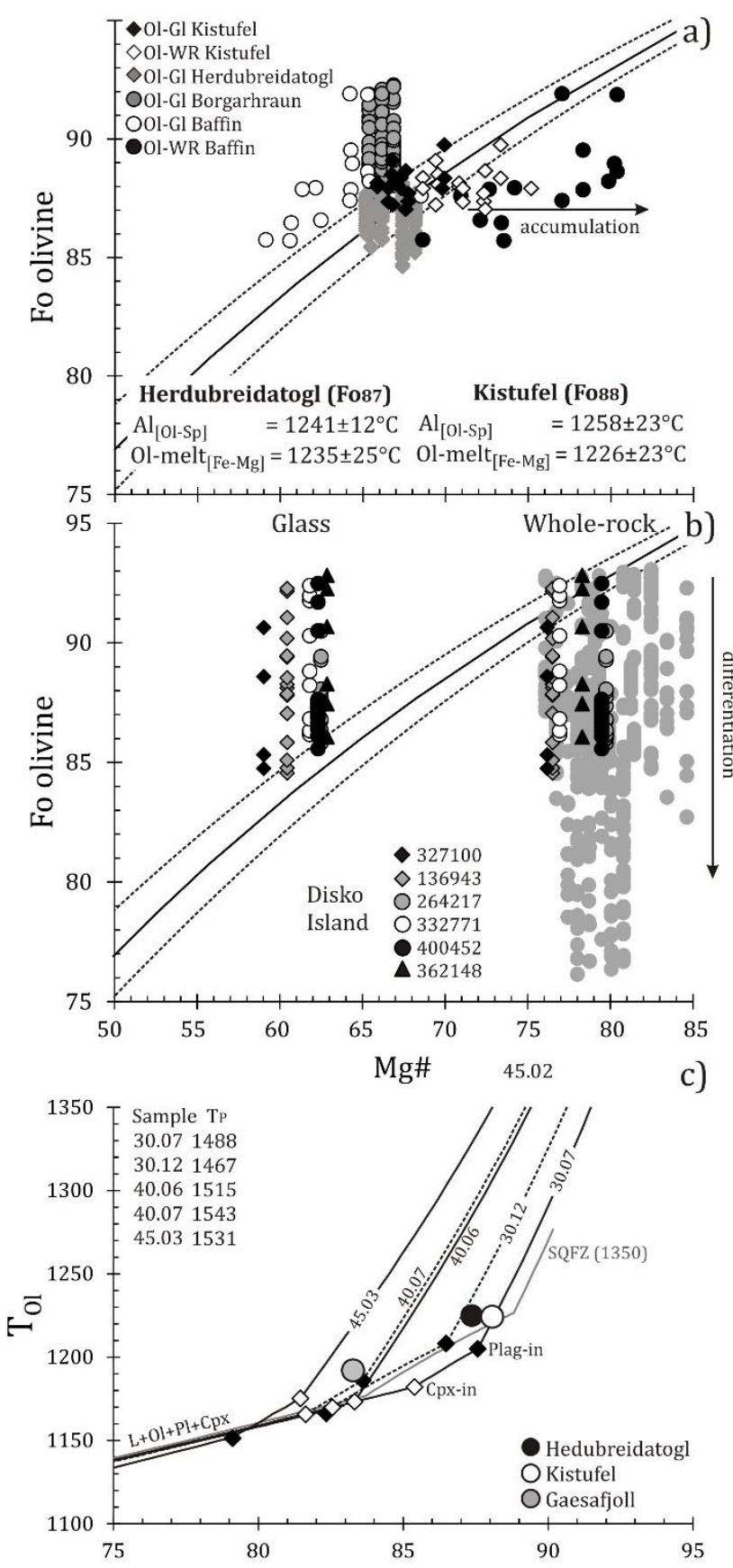

Hole \& Natland Fig.6

Fo olivine 


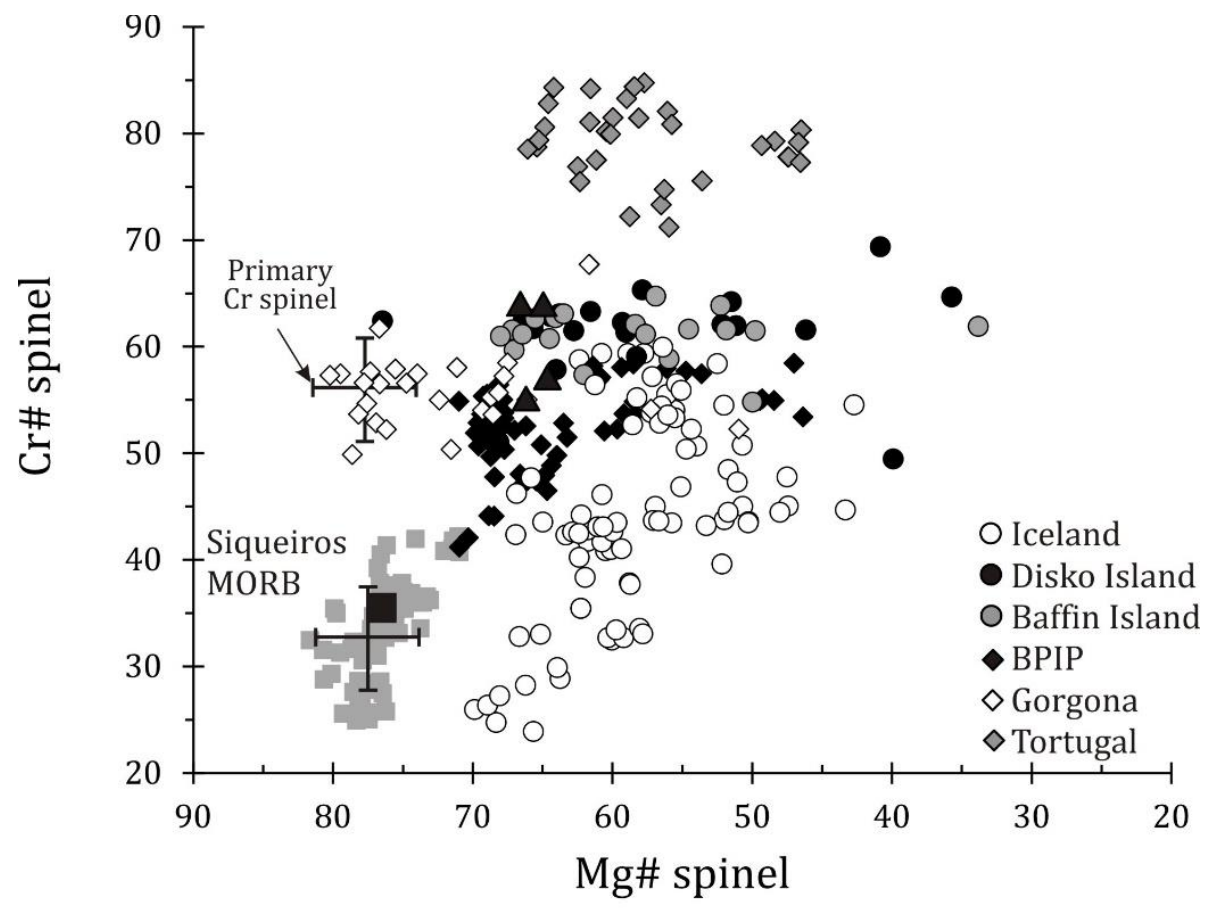

Hole \& Natland Fig. 7 


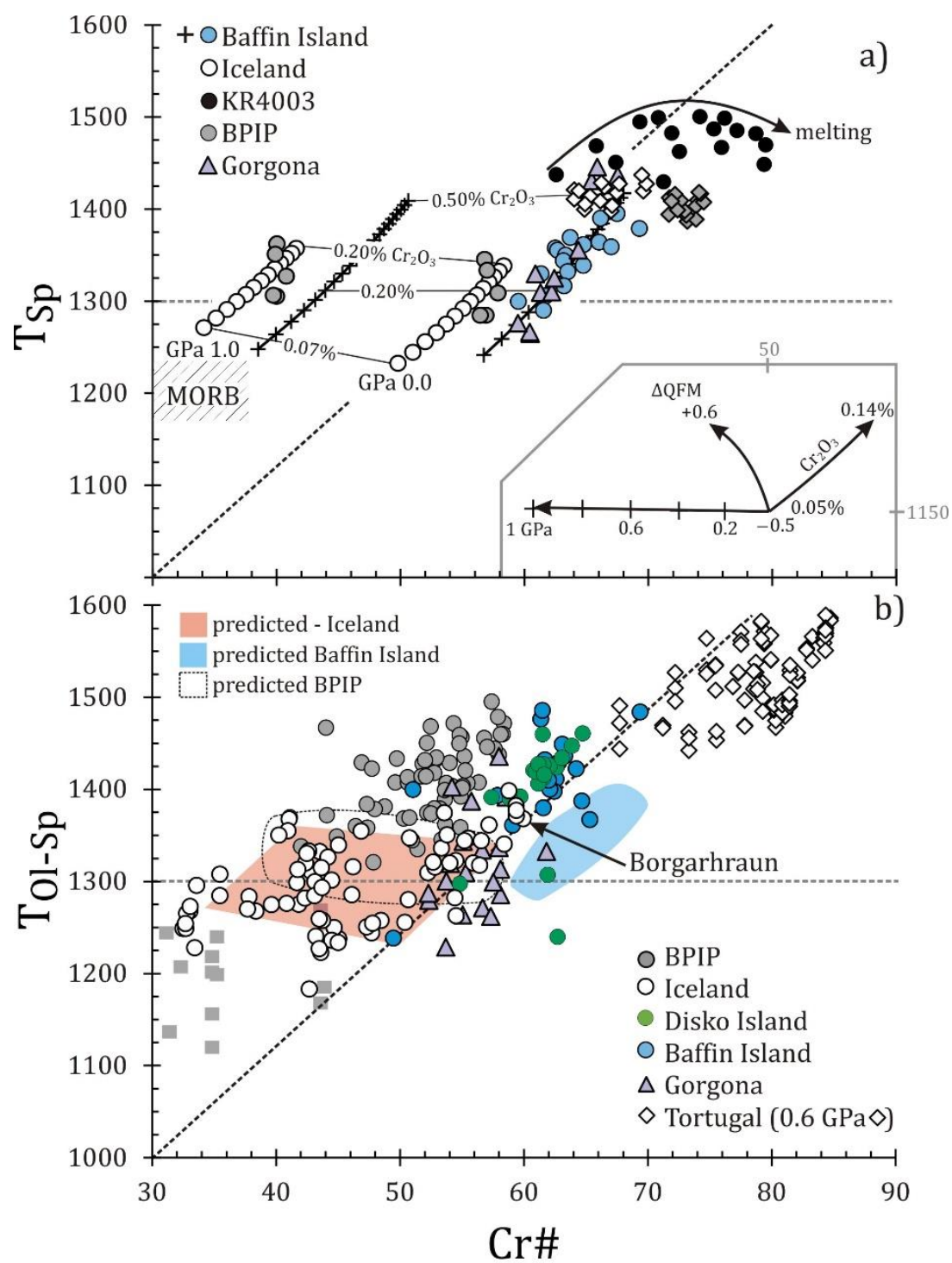

Hole \& Natland Fig. 8 


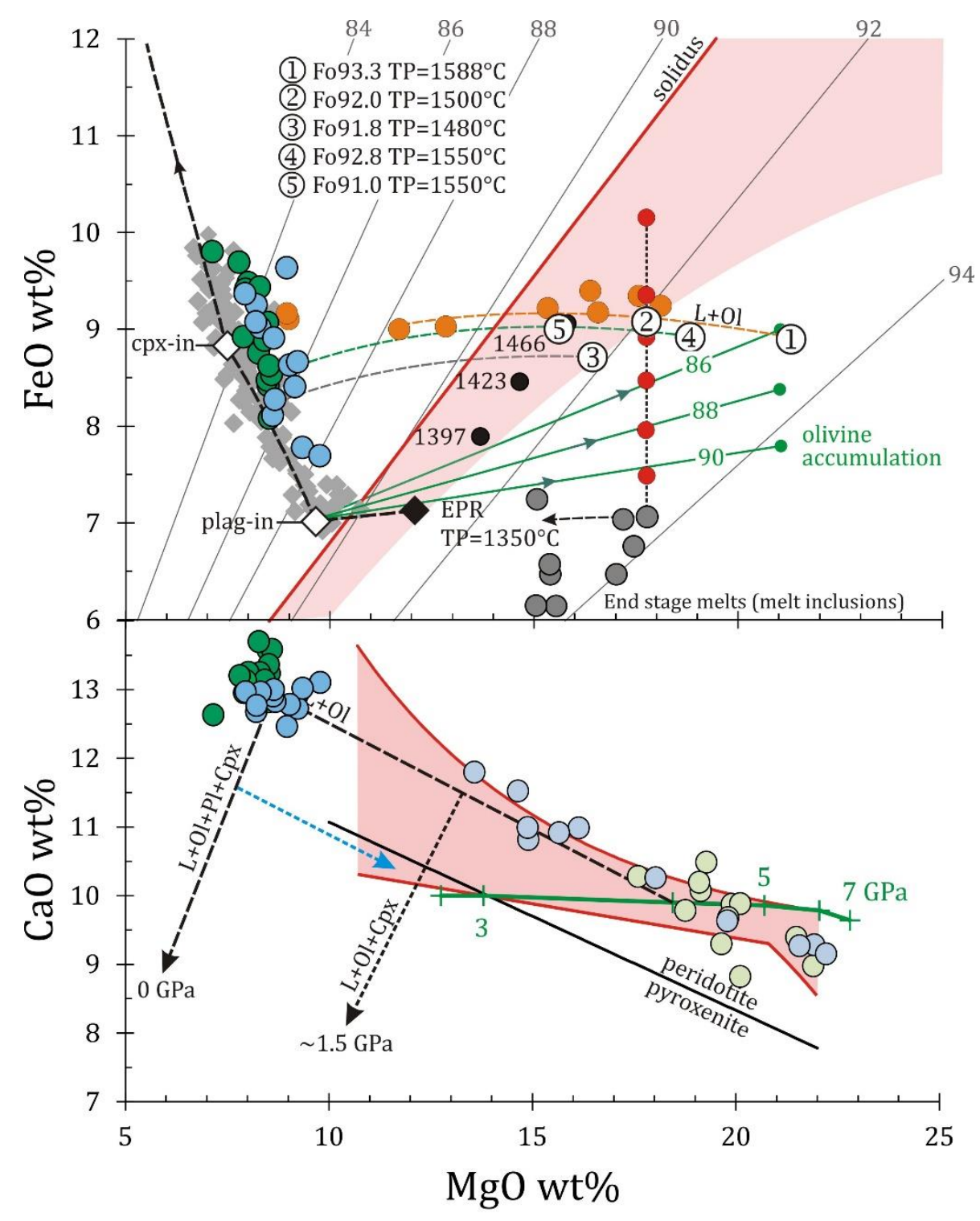

Hole \& Natland Fig. 9 

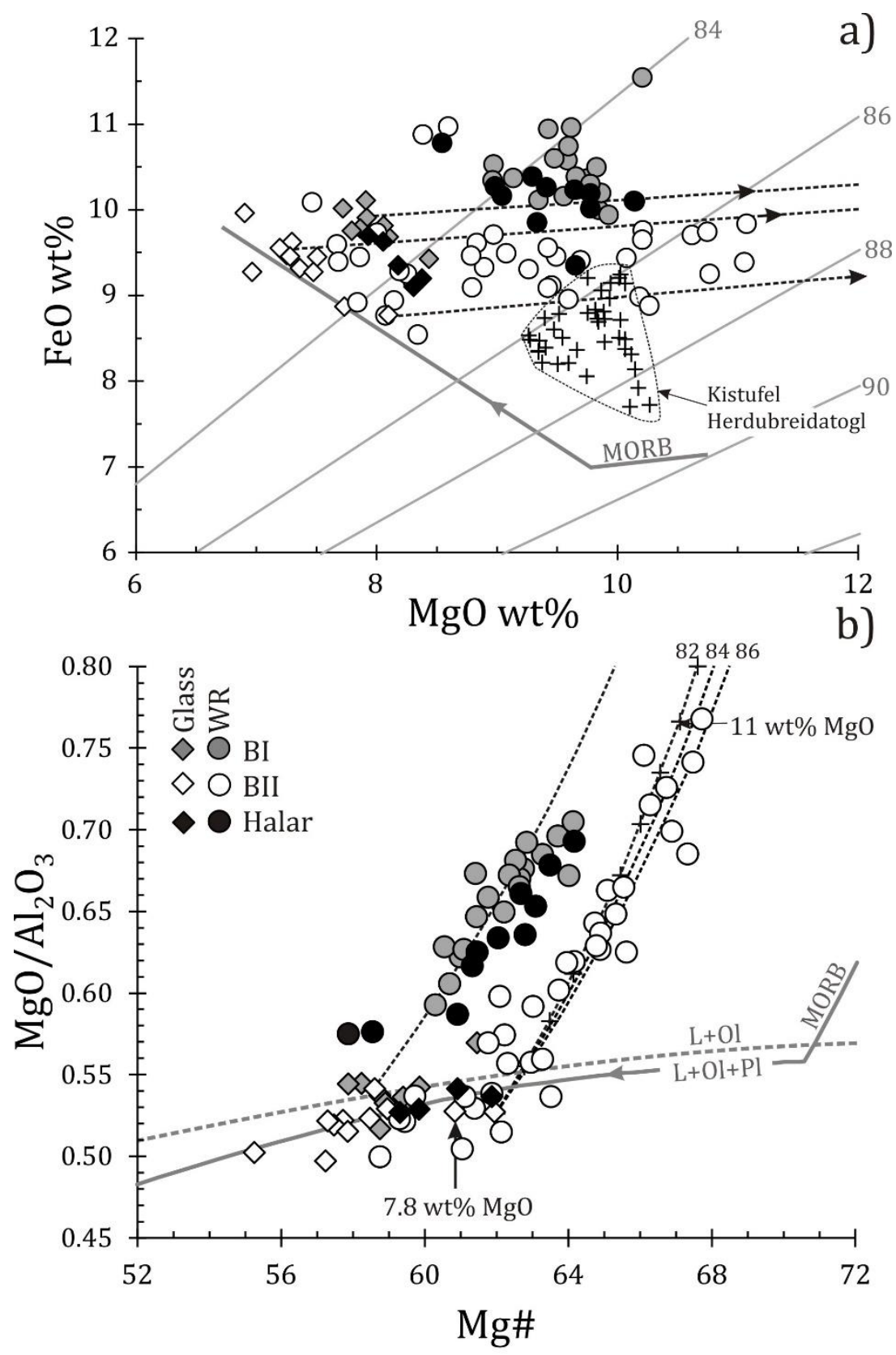

Hole \& Natland Fig. 10 


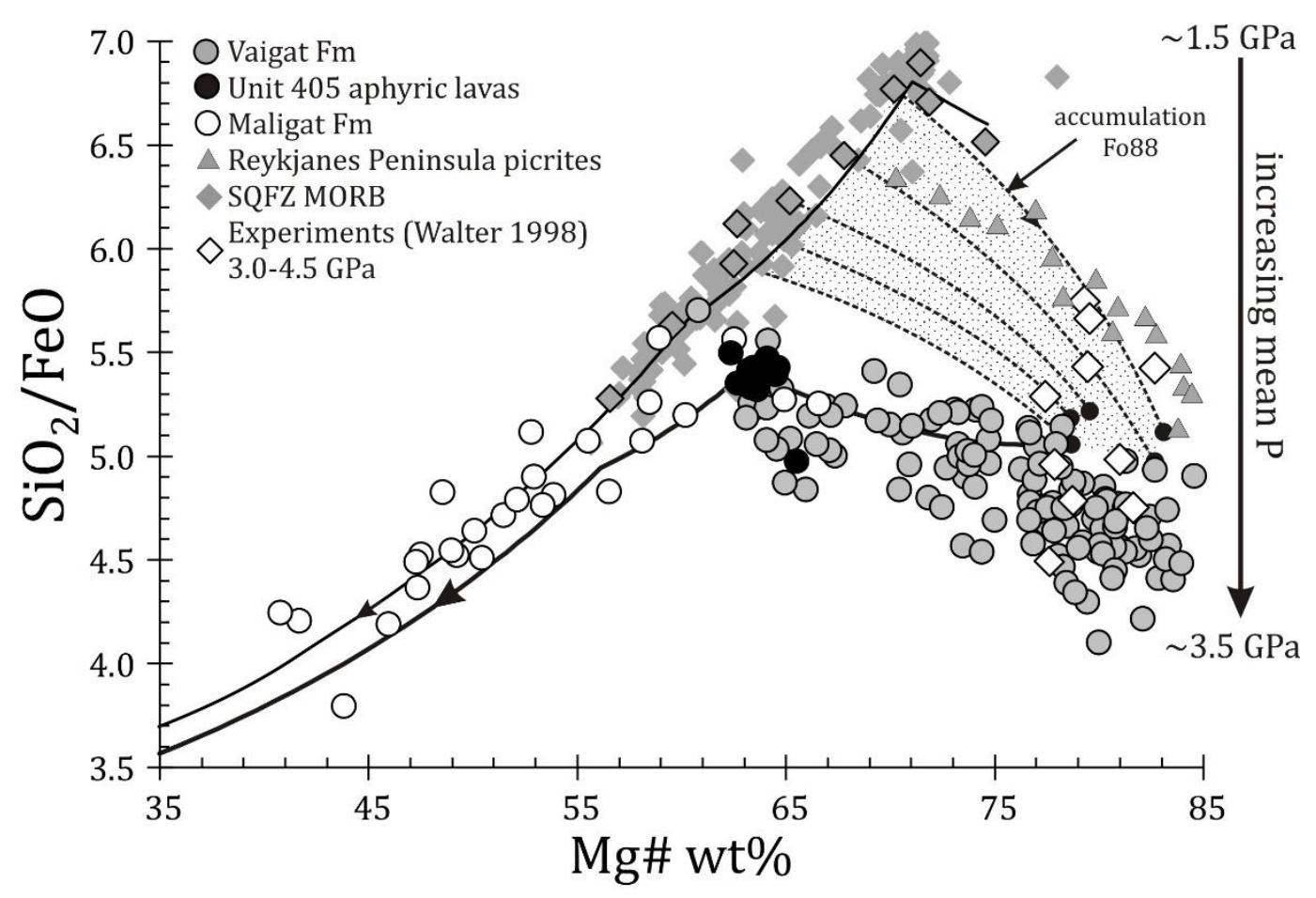

Hole \& Natland Fig. 11 


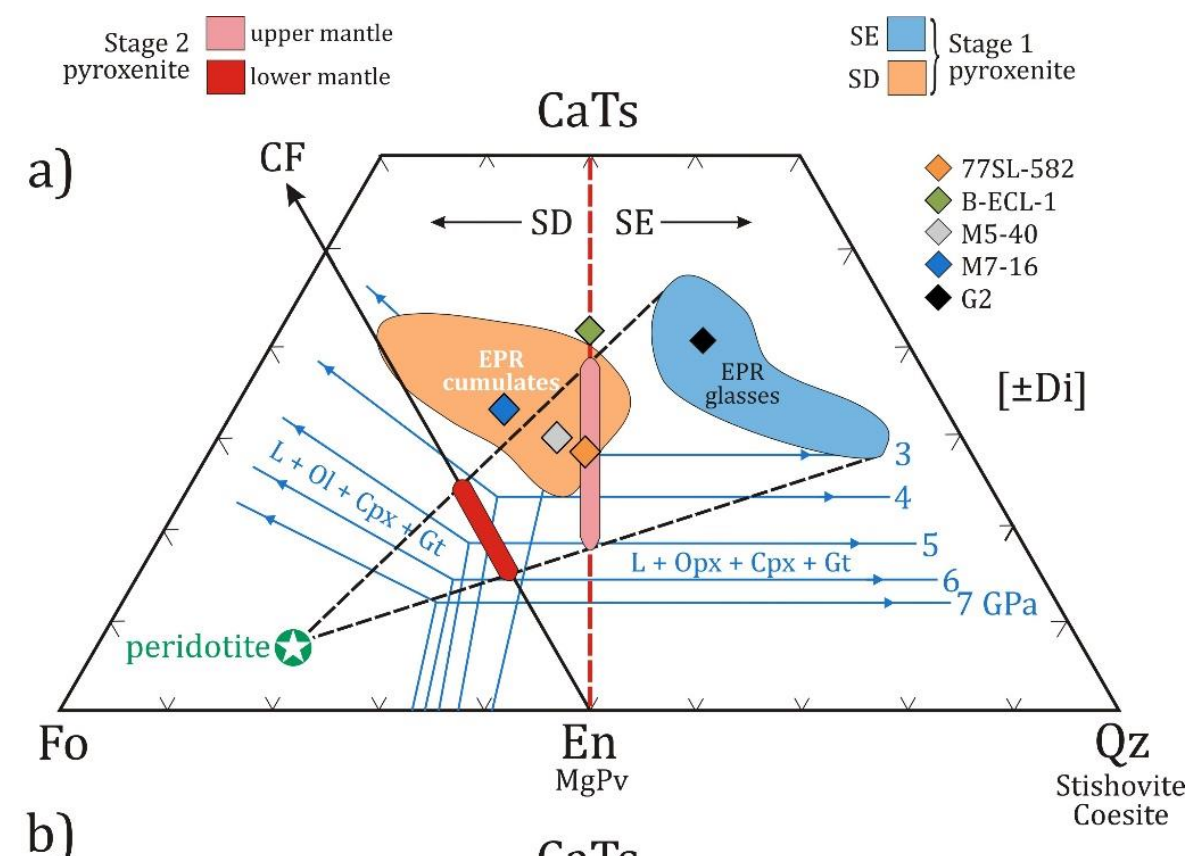

b)

CaTs

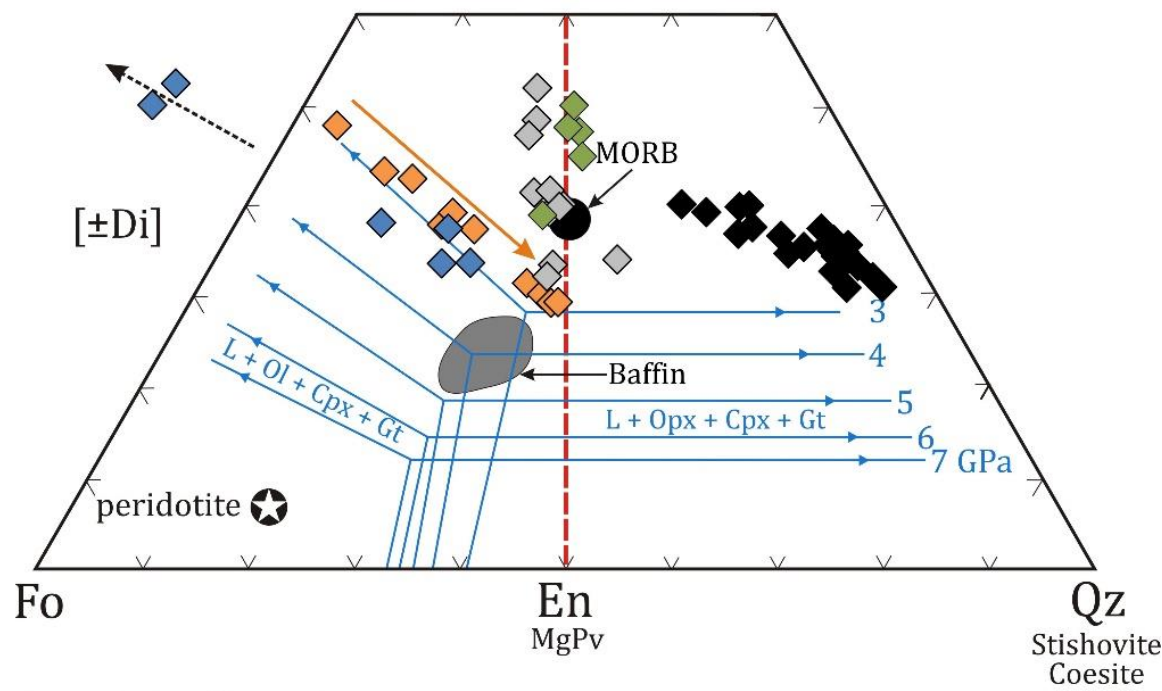

Hole \& Natland Fig. 12 


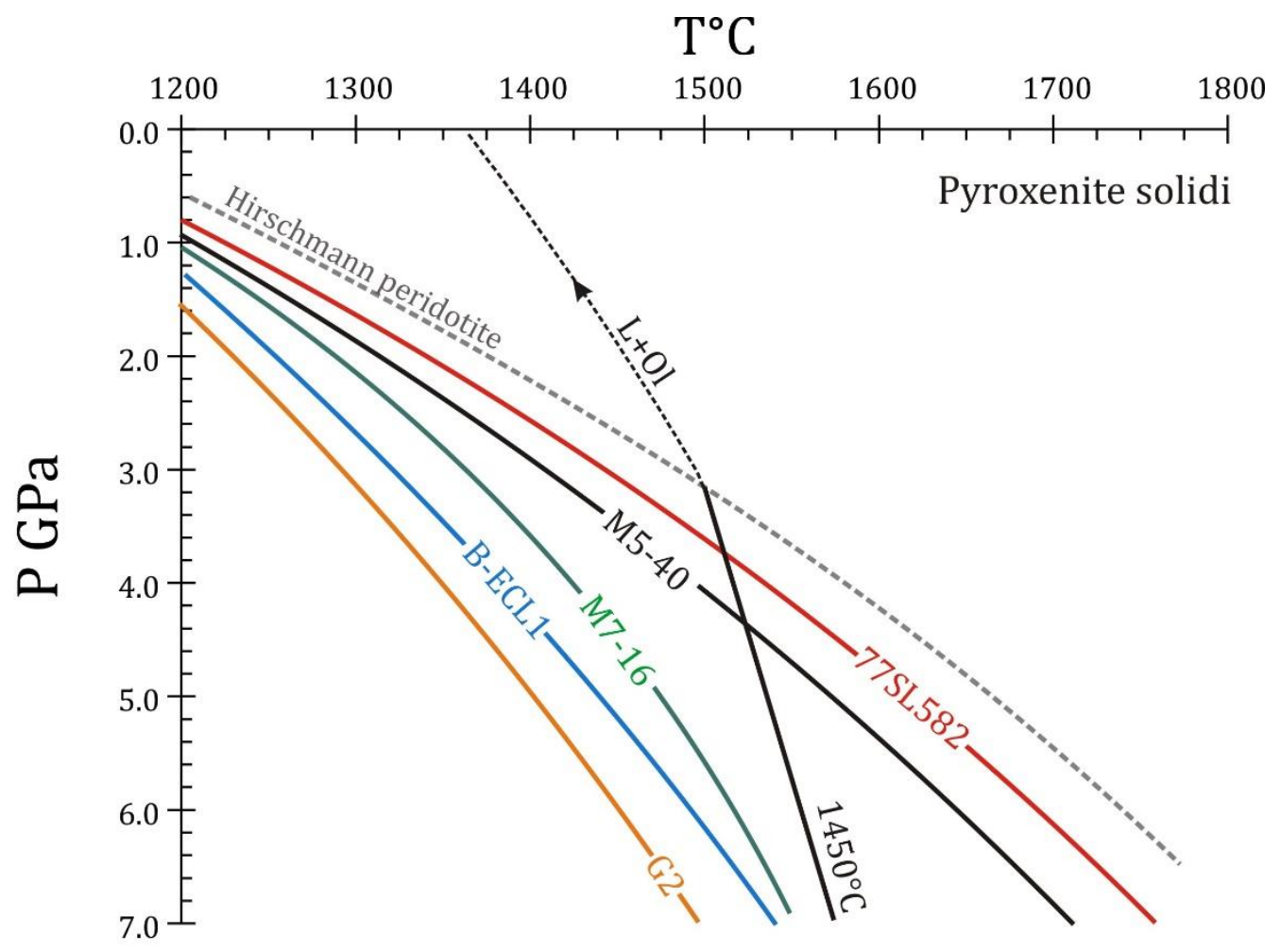

Hole \& Natland Fig. 13 


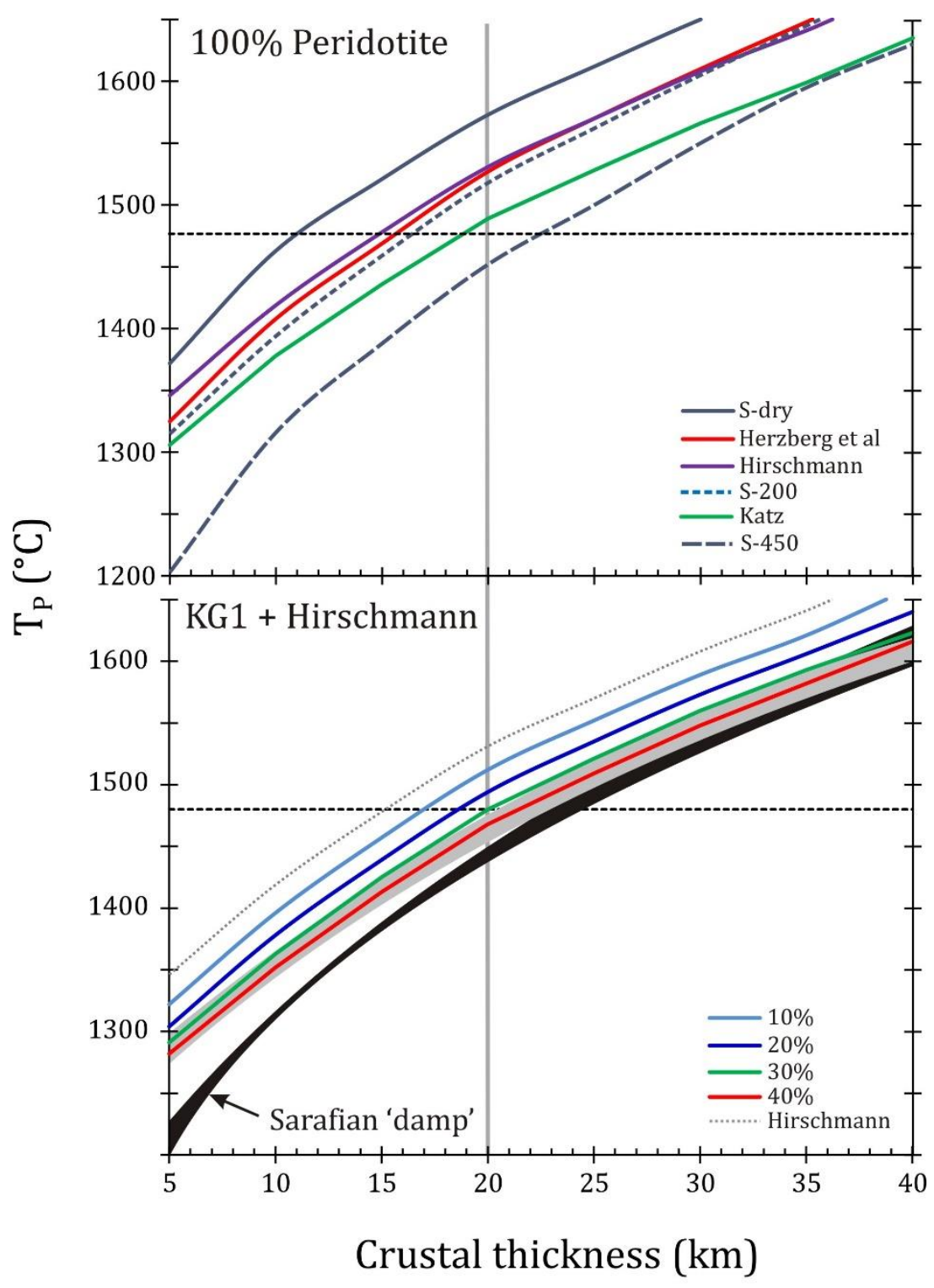

Hole \& Natland Fig. 14 